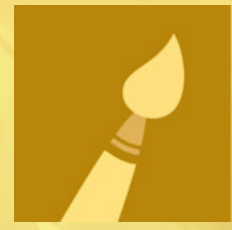

\title{
arts
}

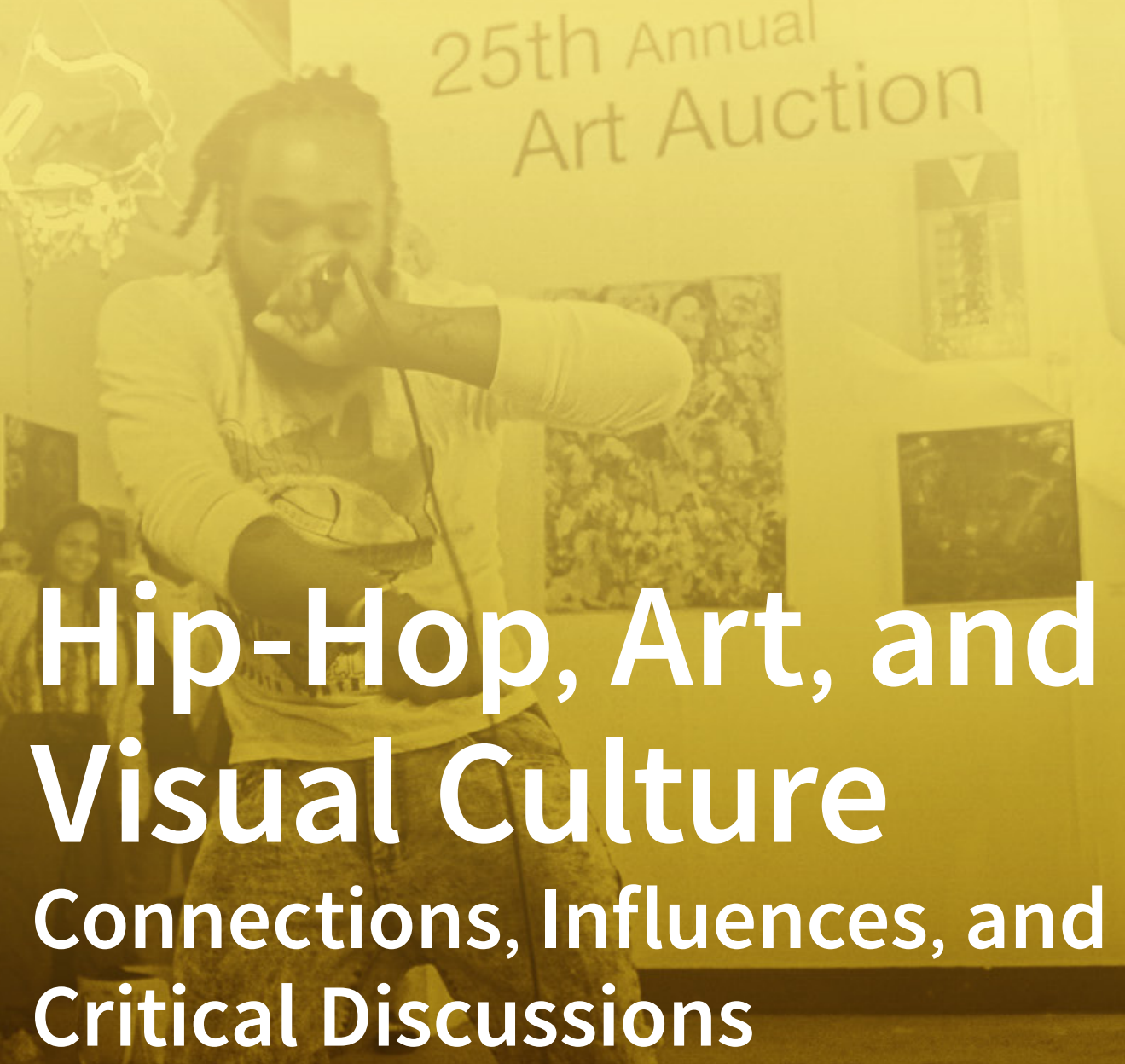


Hip-Hop, Art, and Visual Culture 



\section{Hip-Hop, Art, and Visual Culture: Connections, Influences, and Critical Discussions}

Special Issue Editors

Jeffrey L. Broome

Lisa Munson 
Special Issue Editors

Jeffrey L. Broome

Lisa Munson

Florida State University

Florida State University

USA

USA

Editorial Office

MDPI

St. Alban-Anlage 66

4052 Basel, Switzerland

This is a reprint of articles from the Special Issue published online in the open access journal Arts (ISSN 2076-0752) (available at: https://www.mdpi.com/journal/arts/special_issues/hiphop_art).

For citation purposes, cite each article independently as indicated on the article page online and as indicated below:

LastName, A.A.; LastName, B.B.; LastName, C.C. Article Title. Journal Name Year, Article Number, Page Range.

ISBN 978-3-03928-450-4 (Pbk)

ISBN 978-3-03928-451-1 (PDF)

Cover image courtesy of Mackenzie Broome and Jeffrey L. Broome.

(C) 2020 by the authors. Articles in this book are Open Access and distributed under the Creative Commons Attribution (CC BY) license, which allows users to download, copy and build upon published articles, as long as the author and publisher are properly credited, which ensures maximum dissemination and a wider impact of our publications.

The book as a whole is distributed by MDPI under the terms and conditions of the Creative Commons license CC BY-NC-ND. 


\section{Contents}

About the Special Issue Editors $\ldots \ldots \ldots \ldots \ldots \ldots \ldots \ldots$ vii

Preface to "Hip-Hop, Art, and Visual Culture: Connections, Influences, and Critical

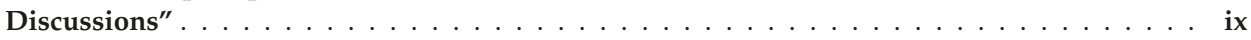

Jeffrey L. Broome and Lisa Munson

Introduction "Hip-Hop, Art, and Visual Culture: Connections, Influences, and

Critical Discussions"

Reprinted from: Arts 2019, 8, 34, doi:10.3390/arts8010034 . . . . . . . . . . . . . . 1

Heather Kaplan

Roberto Lugo: Critical Discussions of Hip-Hop, Ceramics, and Visual Culture

Reprinted from: Arts 2018, 7, 102, doi:10.3390/arts7040102 . . . . . . . . . . . . . . . 5

Melanie L. Buffington and Jolie Day

Hip Hop Pedagogy as Culturally Sustaining Pedagogy

Reprinted from: Arts 2018, 7, 97, doi:10.3390/arts7040097 . . . . . . . . . . . . . . . 23

Nicholas Leonard

Homage or Biting Lines: Critically Discussing Authorship, Creativity, and Copyright in the 21st

Century through Hip-Hop

Reprinted from: Arts 2018, 7, 86, doi:10.3390/arts7040086 . . . . . . . . . . . . . . . . 35

\section{Adam de Paor-Evans}

The Intertextuality and Translations of Fine Art and Class in Hip-Hop Culture

Reprinted from: Arts 2018, 7, 80, doi:10.3390/arts7040080

\section{Jeffrey L. Broome}

Hip Hop Family Tree Treasury Editions: A Book Review for Art and Visual Culture Educators

Reprinted from: Arts 2019, 8, 5, doi:10.3390/arts8010005 . . . . . . . . . . . . . . . 59 



\section{About the Special Issue Editors}

Jeffrey L. Broome is an associate professor and director of doctoral programming in art education at Florida State University. Jeff's research interests include narrative inquiry, multi-age art education, caring approaches to art curricula, and the intersections between hip-hop, art, and visual culture. He delivers presentations at national and state conferences, international symposia, and at district workshops. Jeff served as the elected Director of the Higher Education Division of the National Art Education Association (NAEA) from 2017-2019, and currently serves as the co-chair of the Art Education Research Institute Symposium. Jeff's manuscripts have been published as book chapters and in many academic journals. He was named the Higher Education Art Educator of the Year by the Florida Art Education Association in 2016 and by the Southeastern Region of NAEA in 2020. Previously, Jeff worked for the University of North Texas, the University of Georgia, and as a public school art teacher where he received a Teacher of the Year Award from Cypress Creek Elementary.

Lisa Munson is a teaching professor and director of undergraduate studies in sociology at Florida State University. Lisa's research interests include social inequality and social justice, pedagogy, teaching innovation and public sociology. Presenting at national conferences and universities, Lisa has also organized multiple symposia, panels and workshops at Florida State University focusing on hip hop and social change. Lisa has published a reader and a textbook for the Sociology of Hip Hop Culture, a course that she designed and launched at Florida State University. The recipient of multiple university teaching awards, Lisa has also received community awards recognizing her leadership and community service. Off campus, Lisa has organized workshops promoting individual and community agency and she has organized, curated and hosted over 50 hip hop showcases highlighting music, dance and visual art. 



\section{Preface to "Hip-Hop, Art, and Visual Culture: Connections, Influences, and Critical Discussions"}

The seminal origins of this book-length printed edition of Arts focusing on hip-hop, art, and visual culture are difficult to pin down. Tracing the beginnings of even a small slice of hip-hop culture (music, for instance) is not an easy endeavor. Such origins are largely described through oral histories, leaving some room for debate even among those who participated in the early development of rap music. For many, it was innovative disc jockeys (DJs) working house parties and dances at community centers in the burrows of New York during the 1970s who are credited with laying the musical foundations for hip-hop (Fricke and Ahearn 2002; Hebdige 2004; Piskor 2014). Nonetheless, there are alternative narratives to this origin, and some key components of hip-hop culture, such as graffiti and b-boying (battle dancing and breakdancing), had certainly existed in urban environments for many years prior to the emergence of the hip-hop DJ.

Neither of us grew up in New York during this era, so it would be disingenuous to claim that we were introduced to hip-hop in those contexts. Perhaps, then, a better explanation of the origins of this book-length publication comes from detailing our own burgeoning awareness and interests in hip-hop. For Jeff-a white, middle-class, cisgender male art educator-this introduction primarily came during the 1980s as a middle school and high school student growing up in a small town in West Virginia. By this time, hip-hop was gaining mainstream exposure in popular media outlets including FM radio and MTV. For Jeff, his initial fascination with the genre was further fueled by his participation in both organized and playground basketball-activities and sites noted for representing a convergence of elements related to hip-hop culture, attitude, and ethos (Woodbine 2016). It was in this social context, when a teammate casually introduced a specific track by De La Soul, that Jeff began to think of hip-hop's use of sampling as a potentially creative act. Jeff noted connections between sampling-or using parts of an existing recording in creating new musical works (Copyright Criminals 2009; Lehmann 2011)—to what he had been learning about postmodern art in his high school art classes. He carried this idea with him into post-secondary education and his future career as an art educator, eventually developing it into a set of instructional strategies, academic presentations, and a published article on using hip-hop as a tool for enhancing critical discussions on postmodern art (Broome 2015a).

For Lisa, a sociologist focusing on social inequality and social justice, the introduction to hip-hop began with a deep love of music and an appreciation for the unique ability of rap music to speak to social issues. In 2011, while working at Florida State University, she developed a unit to teach major sociological perspectives by examining messages expressed within hip-hop culture to an Introduction to Sociology class. Reviewing scholarship on hip-hop culture and discovering that it was a very successful way to reach undergraduates and to help them exercise various perspectives in sociology, Lisa was inspired to expand the material. In 2012, Lisa launched the Sociology of Hip-Hop Culture course where students were challenged to think in new ways about the structural and cultural aspects of the reproduction of inequality. In 2016, she and Dr. Andrew Mannheimer edited a reader for the course, and in 2018, Lisa wrote the first textbook and companion website for the course (Munson 2018; Munson-Weinberg and Mannheimer 2016). Over the last seven years, Lisa has organized three symposia and dozens of panels and workshops, and she has curated and produced over 50 community hip-hop showcases. Lisa believes that the academic examination of hip-hop culture using a sociological lens is a powerful way to illuminate critical social issues and, with community 
engagement, can promote public sociology.

Although our interests in hip-hop developed at different times and in different contexts, our paths eventually crossed at Florida State University where we had both settled in our respective academic careers in art education and sociology. Interestingly, though, it was a local elementary music teacher-not the university system - who made us aware of the interdisciplinary connections between our work. The music teacher, Angelyn Hirai, had worked with both of our children and had been involved in several of Lisa's workshops on the topics of hip-hop, education, and sociology. Noticing the topical intersections in our work after attending one of Jeff's academic conference presentations on hip-hop and art (Broome 2015b), Angelyn took it upon herself to introduce us and made the first suggestion that we work together. Lisa took the initiative from there and invited Jeff to serve as a panelist for her 2017 Symposium in Hip-Hop and Education (full video available at https:/ /youtu.be/iZM3-EJMqrU). We stayed in touch after this event, and shared opportunities and events related to hip-hop studies as they became available.

When Jeff was first approached about the possibility of editing a Special Issue of Arts on hip-hop, art, and visual culture, he immediately contacted Lisa to check on her availability to collaborate on such a project. He knew that her expertise in hip-hop would be instrumental in supporting his own specific interests in art education and hip-hop music and that her valuable contacts would serve the project well in spreading the call for papers and curating an appropriate panel of reviewers. With Lisa's agreement to serve as co-editor in place, the project was underway and eventually resulted in the online publication of the Special Issue in 2019, with the finished project featuring four peer-reviewed articles and a book review. The topics covered within the Special Issue ranged from discussions on identity and cultural appropriation, creativity and copyright in digital media, equity and access as represented in select works of art, and the use of fine art tropes within the sociocultural history of hip-hop.

As the project concluded, we believed that there was much more to be said on these topics and made loose plans to propose academic panel presentations that would feature the authors included in the journal. Apparently, we were not the only ones who felt that our collected work could reach a wider audience; Colin Chen, the Managing Editor of Arts, contacted us with positive feedback on the Special Issue and expressed his interest in publishing a book version for purchase. Excited to have the opportunity to disseminate our work further, we immediately tasked ourselves with reformatting the Special Issue and writing additional introductions, eventually leading to the book that you now hold in your hands.

We close this introduction by expressing our gratitude to all of those who made this book possible, whether it be through their support and introductions, by contributing their written work, or through serving as foundational inspiration during our early orientation to hip-hop culture. It has been our intention to collect essays that make important contributions to broadening discussions on art education and hip-hop beyond the topics of graffiti, fashion, and the use of cyphers in educational contexts. We sincerely hope that we have been successful in our efforts and that this volume offers insight and inspiration for new directions in discussing visual art's ever evolving and influential role in hip-hop culture and education. 


\section{References}

Broome, Jeffrey L. 2015a. Using Hip-Hop Music to Enhance Critical Discussions on Postmodern Art. Art Education 68: 34-39.

Broome, Jeffrey. 2015b. Using Hip-Hop Music to Enhance Discussions on Postmodern Art.

Presentation delivered at the Florida Art Education Association Conference, Naples, FL, USA, October 10. Copyright Criminals. 2009. Directed by Benjamin Franzen. New York: Digital Media Rights.

Fricke, Jim, and Charlie Ahearn. 2002. Yes Yes Y'all: The Experience Music Project Oral History of Hip-hop's First Decade. Cambridge: Da Capo.

Davide Hebdige. 2004. Rap and Hip-Hop: The New York Connection. In That's the Joint!: The Hip-Hop Studies Reader. Edited by Murray Forman and Mark Anthony Neal. New York: Routledge, pp. 223-232.

Lehmann, Ulrich. 2011. Sampling and the Materiality of Sound. In Postmodernism: Style and Subversion, 1970-1990. Edited by Glenn Adamson and Jane Pavitt. London: V\&A Publishing, pp. 178-181.

Munson, Lisa. 2018. Sociology of Hip Hop Culture. Kendall Hunt.

Munson-Weinberg, Lisa and Andrew Mannheimer. 2016. Sociology of Hip Hop Culture: A Reader. Pearson Learning Solutions.

Piskor, Ed. 2014. Hip Hop Family Tree: 1975-1983. [Gift Box Set]. Seattle: Fantagraphics.

Woodbine, Onaje X. O. 2016. Black Gods of the Asphalt: Religion, Hip-Hop, and Street Basketball. New York: Columbia University Press.

Jeffrey L. Broome, Lisa Munson

Special Issue Editors 

Editorial

\title{
Introduction "Hip-Hop, Art, and Visual Culture: Connections, Influences, and Critical Discussions"
}

\author{
Jeffrey L. Broome ${ }^{1, *}$ and Lisa Munson ${ }^{2}$ \\ 1 Department of Art Education, Florida State University, Tallahassee, FL 32306-1232, USA \\ 2 Department of Sociology, Florida State University, Tallahassee, FL 32306-1232, USA; lisa.munson@fsu.edu \\ * Correspondence: jbroome@fsu.edu
}

Received: 25 February 2019; Accepted: 5 March 2019; Published: 7 March 2019

Visual art has been tied to hip-hop culture since its emergence in the 1970s. Commentary on these initial connections often emphasizes the importance of graffiti and fashion during hip-hop's earliest days (Fricke and Ahearn 2002). Forty years later, hip-hop music has grown in to a billion-dollar industry (Watson 2004), and its relationship with visual art has also evolved. During the genre's first decades of existence, notable hip-hop practitioners whose work crossed the boundaries of music and visual art included Fab 5 Freddy (Fricke and Ahearn 2002), Lady Pink (Piskor 2014), Rammellzee, and Jean-Michel Basquiat (Nosnitsky 2013). More current examples of such cross-disciplinary efforts include (a) the mixed media performances of Eclectic Method (Copyright Criminals 2009), (b) Swizz Beatz's efforts to create and collect visual art while also producing rap music (Giles 2014), and (c) the Hi-ARTS non-profit organization's initiatives in supporting hip-hop artists in theatre, visual art, dance, and music (Hi-ARTS 2019). Meanwhile, references to visual artists and art have appeared more frequently in the lyrics and music videos of such hip-hop musicians as Jay-Z, Beyoncé, Nas, Kanye West, Substantial, Rick Ross, and Lil Wayne. An overt example of these references can be found in the Carters' (2018) award-winning music video for "Apeshit," filmed in the Louvre Museum in Paris and featuring iconic works of Western art.

Hip-hop has become an established global phenomenon, influencing many facets of society including art, art education, and visual culture. The possibilities and ramifications of this influence have been noted by many scholars and educators. A number of these authors have discussed connections between hip-hop and visual art (Ross 2003), fashion (Whitley 2011), and postmodernism (Lehmann 2011; Potter 1995), while others have explored the use of hip-hop in art education as a tool for critically examining visual culture (Chung 2007; Clinton 2010) or aesthetics (Broome 2015). For this special book-length printed edition of Arts, we invited contributors-either practitioners or scholars-to join these ongoing conversations by submitting manuscripts that further explore the connections between hip-hop, art, and visual culture.

In the opening chapter, Kaplan (2018) focuses on the work of "ghetto potter" Roberto Lugo, a contemporary ceramic artist, whose "hip-hop aesthetic" creates a space in visual arts that challenges white visual hegemony and privilege. The author explores the intersections of ceramics, hip-hop, and visual culture, focusing on representation, access, and equity within art education. Kaplan presents a compelling argument for greater inclusion and diversity within visual art and art education, illuminating Lugo's pedagogical approaches centered on promoting opportunity for voices typically excluded within dominant discourse.

Buffington and Day (2018) present a nuanced argument that Hip-Hop Pedagogy can be implemented as a type of culturally responsive instruction. Art educators can consider adopting similar strategies when developing their own approaches to culturally sustaining pedagogy. The authors urge educational practitioners to move beyond the use of cyphers to attract students to academic subjects, and to instead make meaningful connections to works of art more directly related to the hip-hop genre itself. When selecting examples for class discussions, Buffington and Day remind us of the importance 
of featuring women and gender minority artists as focal points for art curricula. As a guiding example, the authors discuss the work of contemporary artist, Rozeal, and the implications of her art in initiating classroom dialogue on identity and cultural appropriation.

In the third chapter in this volume, Leonard (2018) describes ways in which art educators can use hip-hop to foster critical discussions on the topics of creativity, copyright, and authorship in digital media. By making relatable connections to "sample-based hip-hop music" (Schloss 2004), art teachers may increase student engagement toward legal and creative issues involved in the production of digital artwork.

The final chapter by De Paor-Evans (2018) argues for a critical relationship between hip-hop and fine art, exploring the "intertextuality between visual and sonic metaphors" produced by hip-hop artists, while challenging the class-based labelling of hip-hop as a "mainstream" or "lowbrow" culture. The author situates his analysis within the framework of Bourdieu's theories of distinction, establishing a sociocultural history of hip-hop culture, examining cultural capital and promoting the use of fine art tropes in the analysis of cultural production in hip-hop.

This volume closes with Jeff's own review of Ed Piskor's Hip Hop Family Tree comic book series, recently compiled and packaged into gift box sets by Fantagraphics (Piskor 2014, 2016). These collected works use a graphic novel format to chronicle the early development of hip-hop culture from the mid-1970s to 1985 . Jeff concludes his book review by suggesting ways in which art and visual culture educators can use Piskor's work as a catalyst for introducing social justice issues, postmodern principles, and the use of arts-based historical research methods.

In conclusion, we would like to thank the editorial board and staff at Arts for giving us this opportunity to assemble a collection of academic work on the topic of hip-hop and visual art. Without the tireless efforts of such a hardworking staff, this issue would not have been possible. We hope that the essays presented here are useful in broadening discussions on the evolving role of visual art in hip-hop culture. As our authors have demonstrated, the possibilities of extending these conversations beyond the topics of graffiti, fashion, and the use of cyphers in educational contexts are vast and fruitful.

Funding: This research received no external funding.

Conflicts of Interest: The authors declare no conflict of interest.

\section{References}

Broome, Jeffrey L. 2015. Using Hip-Hop Music to Enhance Critical Discussions on Postmodern Art. Art Education 68: 34-39. [CrossRef]

Buffington, Melanie L., and Jolie Day. 2018. Hip Hop Pedagogy as Culturally Sustaining Pedagogy. Arts 7: 97. [CrossRef]

Chung, Sheng Kuan. 2007. Media/visual Literacy Art Education: Sexism in Hip-hop Music videos. Art Education 60: 33-38. [CrossRef]

Clinton, Zerric. 2010. What African American Male Adolescents Say about Music Videos with Implications for Art Education. Ph.D. dissertation, Florida State University, Tallahassee, FL, USA.

Copyright Criminals. 2009. Directed by Benjamin Franzen. New York: Digital Media Rights.

De Paor-Evans, Adam. 2018. The Intertextuality and Translations of Fine Art and Class in Hip-Hop Culture. Arts 7: 80. [CrossRef]

Fricke, Jim, and Charlie Ahearn. 2002. Yes Yes Y'all: The Experience Music Project Oral History of Hip-hop's First Decade. Cambridge: Da Capo.

Giles, Matthew. 2014. Swizz Beatz Wants to Change the Art World. Vulture, November 25. Available online: http:/ / www.vulture.com/2014/11/swizz-beatz-wants-to-change-the-art-world.html (accessed on 27 January 2019).

Hi-ARTS. 2019. Our Vision, Our Story. Available online: http:/ /www.hi-artsnyc.org/our-story (accessed on 27 January 2019).

Kaplan, Heather. 2018. Robert Lugo: Critical Discussions of Hip-Hop, Ceramics, and Visual Culture. Arts 7: 102. [CrossRef] 
Lehmann, Ulrich. 2011. Sampling and the Materiality of Sound. In Postmodernism: Style and Subversion, 1970-1990. Edited by Glenn Adamson and Jane Pavitt. London: V\&A Publishing, pp. 178-81.

Leonard, Nicholas. 2018. Homage of Biting Lines: Critically Discussing Authorship, Creativity, and Copyright in the 21st Century through Hip-Hop. Arts 7: 86. [CrossRef]

Nosnitsky, Andrew. 2013. Basquiat's 'Beat Bop': An Oral History of One of the Most Valuable Hip-Hop Records of All Time. Spin, November 14. Available online: http://www.spin.com/articles/beat-bop-basquiat-k-robrammellzee-freak-freak/ (accessed on 6 December 2018).

Piskor, Ed. 2014. Hip Hop Family Tree: 1975-1983. [Gift Box Set]. Seattle: Fantagraphics.

Piskor, Ed. 2016. Hip Hop Family Tree: 1983-1985. [Gift Box Set]. Seattle: Fantagraphics.

Potter, Russell A. 1995. Spectacular Vernaculars: Hip-hop and the Politics of Postmodernism. Albany: State University of New York Press.

Ross, Andrew. 2003. Princes Among Thieves: Sampling the '80s. Art Forum 41: 248-83.

Schloss, Joseph. G. 2004. Making Beats: The Art of Sample-Based Hip-hop. Middletown: Wesleyan University Press. Watson, Julie. 2004. Rapper's Delight: A Billion-Dollar Industry. Forbes, February 18. Available online: https: //www.forbes.com/2004/02/18/cx_jw_0218hiphop.html\#2113bf44672d (accessed on 27 January 2019).

Whitley, Zoe. 2011. Dressing Viciously: Hip-hop Music, Fashion and Cultural Crossover. In Postmodernism: Style and Subversion, 1970-1990. Edited by Glenn Adamson and Jane Pavitt. London: V\&A Publishing, pp. 187-91.

(C) 2019 by the authors. Licensee MDPI, Basel, Switzerland. This article is an open access article distributed under the terms and conditions of the Creative Commons Attribution (CC BY) license (http:/ / creativecommons.org/licenses/by/4.0/). 



\title{
Article \\ Roberto Lugo: Critical Discussions of Hip-Hop, Ceramics, and Visual Culture
}

\author{
Heather Kaplan \\ Department of Art, The University of Texas at El Paso, El Paso, TX 79968, USA; hgkaplan@utep.edu \\ Received: 30 September 2018; Accepted: 6 December 2018; Published: 10 December 2018
}

\begin{abstract}
This paper looks at the creative work of "ghetto potter" Roberto Lugo. Through the examination of his various forms of art-making, various discussions regarding the intersections of ceramics, hip-hop, and visual culture are explored. Through these intersections, issues related to access and equity are explored. This paper explores topics and issues important to visual culture and art education.
\end{abstract}

Keywords: hip-hop; ceramics; visual culture; Roberto Lugo; identity politics; porcelain

\section{Introduction}

This paper looks to the work of contemporary ceramic artist Roberto Lugo as a way to understand and theorize on the connection between hip-hop and visual arts and visual culture. Lugo, an artist of many forms, including graffiti art, spoken word poetry, or rap, and the form for which he has received the most acclaim, contemporary pottery, is the embodiment or practice of hip-hop's intersection with the visual. This paper explores how his practices are situated within the vernacular of hip-hop, how the work he creates functions similarly to the politics of rap and hip-hop in that it creates a space for identities and narratives that counter white cultural hegemony, and how his work can be used to unpack the way that form and ideas intersect in order to explore the connections between meaning, message, and material in art education.

Lugo's work has created a forum for black social consciousness and called into question practices and privileges inherent and specific to the field of ceramics. Because of this, his work speaks to larger visual culture and social justice concerns of representation, visuality, and power, laid bare through reimagining and reclaiming (cultural) space. Lugo does this through a "hip-hop aesthetic", meaning both cultural productions and civic, political, and artistic practices that originate from and contribute to contemporary notions of urban black culture and politics. More specifically, Lugo's hip-hop aesthetic speaks to black consciousness raising, questioning white visual hegemony, visuality, and visual culture.

Roberto Lugo explains that his practice encompasses a variety of methods, including being a "potter, activist, culture-maker, rapper, poet, and educator;" (Lugo, personal communication July 2018), yet his rising star is specifically in the ceramics world. This very year, 2018, Ceramics Art Network, Ceramics Monthly, and Pottery Making Illustrated all named him the ceramic artist of the year. In 2015, Lugo was named a National Council for Education in the Ceramic Arts (NCECA) Emerging Artist of the Year. So, while Lugo's work takes many forms, it seems that the world of ceramics is claiming much of his work as their own. For many in the ceramics field, this is seen as a windfall, especially for a field that has been criticized for its white monoculture and the hierarchy that it historically placed on white porcelain from Europe and Asia.

\section{How Roberto Lugo's Pottery Questions the Practice of Privileging White Bodies}

Historically, great value has been placed on porcelain ceramics. This is largely due not only to the material's qualities (being both highly refined and able to create thin, delicate wares that are also 
resiliently strong) but also because of its initial scarcity (De Waal 2016). Porcelain originated from Jingdezhen, China and was initially only available through trade with the East. From the 13th century until the beginning of the 18th century, porcelain was an expensive import that was not producible in Europe. Even after it was able to be manufactured in Germany and England, porcelain remained "for the refined, for the ruling class, with all of its power and privilege" (La Force 2015). In ceramics, metaphors of clay bodies and the body prevail, and it is no mistake that porcelaneous and white bodies are often fetishized for their elite refinement produced not only by their comparatively smaller and finer particle size but for their relationship to white bodies, culture, and general qualities of whiteness. Where whiteness refers not only to a sense of purity, cleanliness, and sterility, it also refers to a cultural structure of power and privilege often invisible and described by a lack rather than as a set of visible characteristics (Lopez 2005). In the field of ceramics, whiteness implies a lack of voices from people from diverse and different cultural heritage; typically, ceramics draws its historical roots from Asia and Europe (rather than from indigenous people of the Americas, Africa, or Oceania) (Gupta Wiggers 2013) and practitioners are, more often than not, of European or Asian heritage.

As the son of Puerto Rican immigrants, Lugo grew up "in a poverty blighted neighborhood of Philadelphia" (Brown 2017, p. 54). He proudly declares that his lineage has African roots (Brown 2017, p. 56) and that he identifies as and with people of color. While many may see the inclusion of underrepresented minorities like Lugo in the pottery tradition as progress, what is all the more exciting is that the work, which is about the clash of two disparate cultures, has been widely embraced by the field. Lugo is not a minority artist in name only; his work speaks to forms and ideas that wrestle between minority and mainstream culture, low and high culture, popular and niche markets, contemporary urbanity and historical gentility, blackness and whiteness, and hip-hop and pottery.

Lugo creates works that often employ familiar European and Asian pottery forms like the urn, teapot, and tea bowl that are ornately decorated, often using gold luster and china paint. The works involve the layering of ornamental pattern like those found in other craft and industrialized art forms, including fabrics and printed wallpapers, and are employed in a style similar to Vienna Secessionist Gustav Klimt. These patterns fill the entire form, save for the spaces that Lugo leaves for equally detailed rendered portraits of persons of historical, political, cultural, or social import. Often, Lugo juxtaposes two like or unlike figures to coax the viewer into understandings precipitated through their connections and comparisons. For instance, the work The Expulsion of Colin Kaepernick and John Brown, 2017 (Figures 1 and 2) has China painted images of both the former San Francisco 49ers quarterback, and now free agent Colin Kaepernick and the American abolitionist John Brown. Lugo places the portraits of Kaepernick and Brown on opposite sides of the same porcelain urn as if two sides of the same coin. This helps the viewer to make connections between the revolutionary actions of John Brown, who led a raid on the arsenal at Harpers Ferry, West Virginia on 16 October 1859 in the hopes of arming slaves and starting a slave rebellion (Bisson 2009), and the contemporary and controversial actions of Colin Kaepernick, who took a knee during the National Anthem in order to rally others, ignite conversation, and bring further attention to the Black Lives Matter movement (Gregory 2017), a movement that questions white power structures and latent cultural beliefs that ultimately lead to the death and brutalization of African Americans at the hands of law enforcement. 


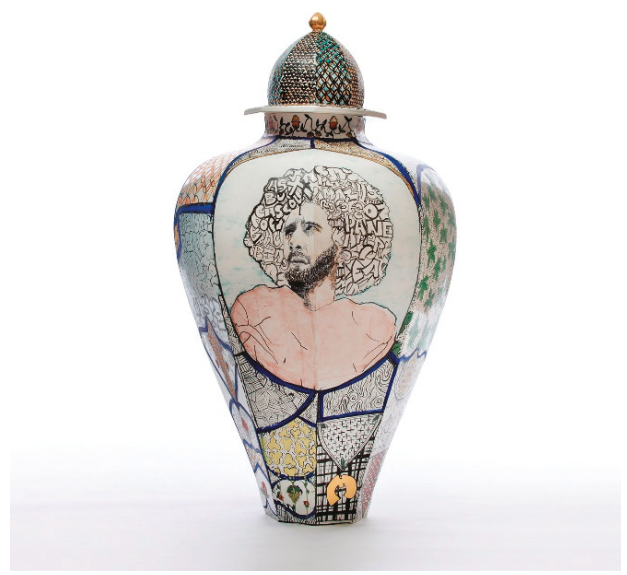

Figure 1. The Expulsion of Colin Kaepernick and John Brown, 2017, Porcelain, china paint, luster, $47 \times 24$ $\times 24$ in. Image by KeneK Photography, courtesy of Wexler Gallery.

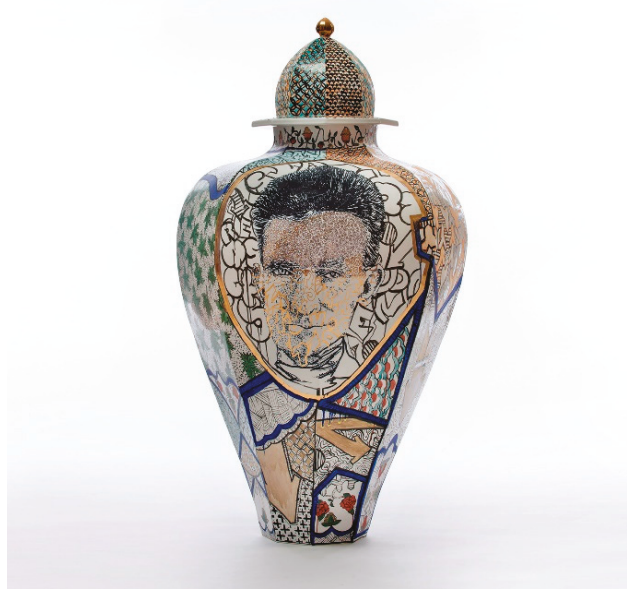

Figure 2. The Expulsion of Colin Kaepernick and John Brown, 2017, Porcelain, china paint, luster, $47 \times 24$ $\times 24$ in. Image by KeneK Photography, courtesy of Wexler Gallery.

In western art history and institutions, ceramics is a smaller field than other "fine art" fields, like painting and sculpture. Therefore, fewer people have studied the field (Brown 2006, p. 38), even fewer are familiar with contemporary ceramics, and fewer still with contemporary pottery and the people and practices involved in it. This can lead to isolated or niche cultural practices. On the other hand, hip-hop and rap, though originally minority cultural forms, are much more widely dispersed within the larger visual and cultural realms. This is possibly in part because of the very form, popular music, which constitutes hip-hop and rap (the ceramic medium and the delicate pots and ceramic sculptures it produces are more difficult to transport or transmit to a mass audience). Unlike traditional ceramics, hip-hop's ease of transmission and the ubiquity of popular music imply that hip-hop is received by and possibly practiced by larger masses of people; it is truly part of popular culture.

By incorporating both minority and popular visual cultural practices in his pottery, Lugo's work seems to be the breath of fresh air that might enliven an insular art form, contemporary pottery, that only a few collectors and practitioners regard as relevant to contemporary culture (Clark 2007, 
p. 103). His remixing and mashing of disparate cultures (hip-hop popular aesthetics, art and crafts patterning, and white porcelain pottery) opens avenues for new ideas and practices in ceramics, while it creates spaces for minority voices and practices in art forms like ceramics that have been historically white and Asian expressions of culture. Lugo's inclusion in the world of pottery stands not only to create new authorship within the field, but his remixing of culture and his activism stands to re-enliven the field through the creation of new vernacular, new viewership, and new modes of exhibition.

\section{Practicing Hip-Hop through Pottery}

Lugo, who calls himself a "ghetto potter", which he defines positively as resourceful rather than as a derogatory term (Lugo n.d.), claims the term hip-hop when referring to his work. He states, "I like to think of myself as a hip-hop artist through pottery." (R. Lugo, personal communication, 6 June 2018) Lugo's recent work makes direct reference to hip-hop culture through visual representations of rap artists and of athletic shoes. In the work titled Method Man and Jimi Hendrix, 2018 (Figures 3 and 4), Lugo depicts the musical artists named in the title on opposite sides of a lidded jar/urn. This work, along with others like A Century of Black Music, 2018 (Figures 5 and 6), draws historical and cultural connections between black musical accomplishments over time and more contemporary and controversial work of hip-hop artists. Additionally, works like Stunting: Pump 1, 2018 (Figures 7 and 8) and Stunting: Clean Joint, 2018 (Figures 9 and 10) use the visual vernacular of athletic or basketball shoes as a clear reference to hip-hop attire. While both works reference athletic footwear, the first clearly references the athletic shoe Reebok Pump through a ceramic representation of the familiar orange plastic pump, replete with the letters "PUMP" and with the bolder, brighter coloring of the Reebok brand. The second employs easily recognizable leather treatments, such as white leather stitching and the regimented patterning of dots, universal to white leather athletic shoes. While the titles may refer to ceramic processes of making a clean joint between two connections in clay, pumping clay slurry for slip casting, or using an air pump for gas kiln burners, the titles clearly refer to hip-hop vernacular: Stunting is urban slang for "showing off". Due to the price of finer athletic shoes, those who wore them often did not do so in order to play sports but did so as a sign of status and of being part of the culture (Stapleton et al. 2005). This point does not appear to be lost to Lugo, who emphasizes it through the use of gold lusters, a lavish finishing application and sign of expense.

Figure 3. Method Man and Jimi Hendrix, 2018, Earthenware and china paint, $13 \times 13 \times 26$ in. Image by KeneK Photography, courtesy of Wexler Gallery. 


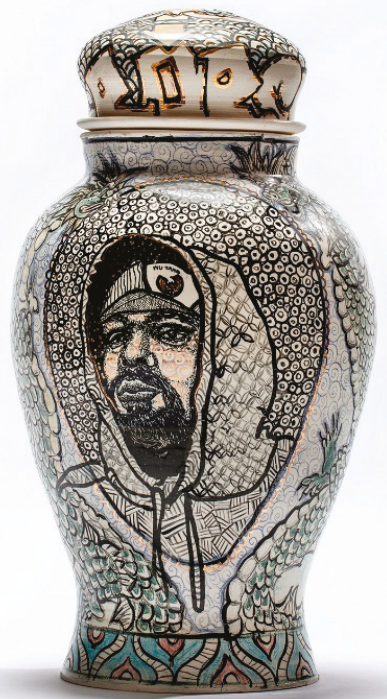

Figure 4. Method Man and Jimi Hendrix, 2018, Earthenware and china paint, $13 \times 13 \times 26 \mathrm{in}$. Image by KeneK Photography, courtesy of Wexler Gallery.

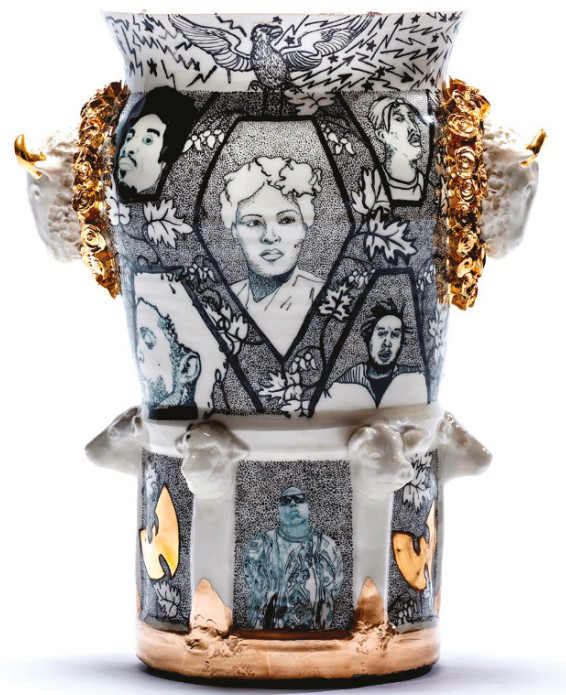

Figure 5. A Century of Black Music, 2018, Porcelain and china paint, $13 \times 9 \times 16$ in. Image by KeneK Photography, courtesy of Wexler Gallery. 


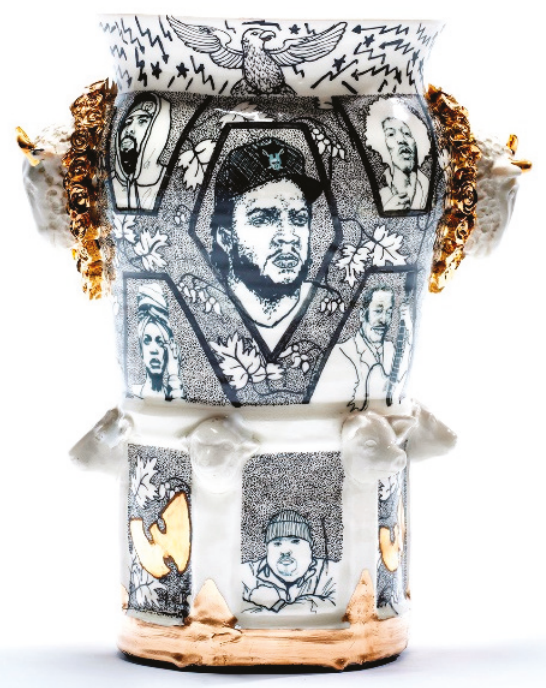

Figure 6. A Century of Black Music, 2018, Porcelain and china paint, $13 \times 9 \times 16$ in. Image by KeneK Photography, courtesy of Wexler Gallery.

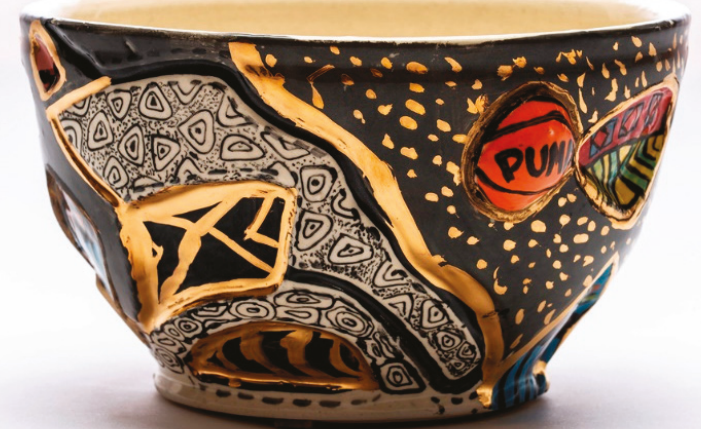

Figure 7. Stunting: Pump I, 2018, Porcelain, china paint, luster, $5 \times 10 \times 10 \mathrm{in}$. Image by KeneK Photography, courtesy of Wexler Gallery. 


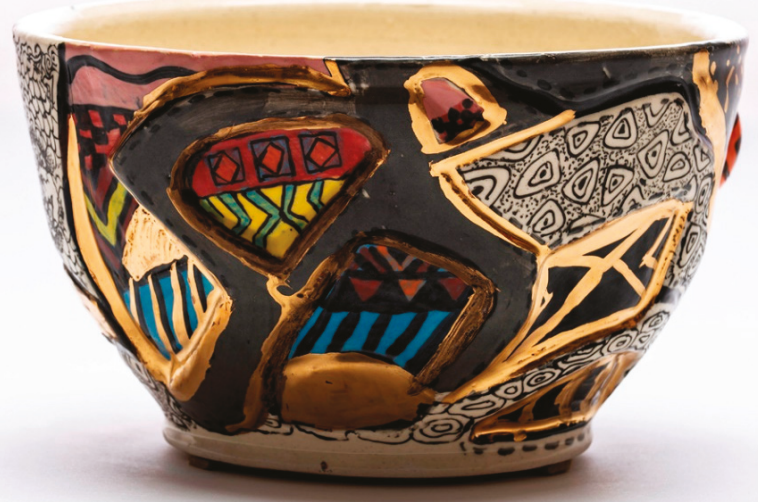

Figure 8. Stunting: Pump I, 2018, Porcelain, china paint, luster, $5 \times 10 \times 10 \mathrm{in}$. Image by KeneK Photography, courtesy of Wexler Gallery.

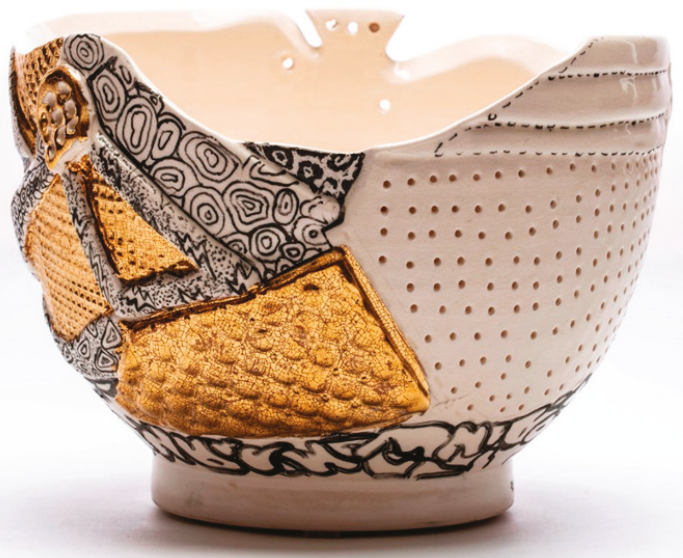

Figure 9. Stunting: Clean Joint, 2018, Porcelain, china paint, luster, $8 \times 10.5 \times 10.5 \mathrm{in}$. Image by KeneK Photography, courtesy of Wexler Gallery. 


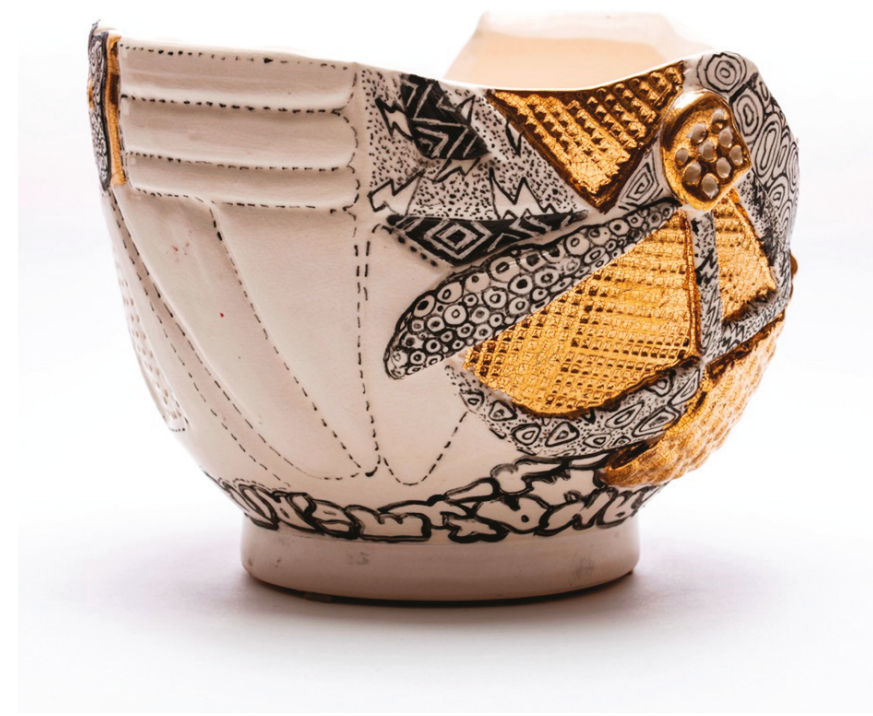

Figure 10. Stunting: Clean Joint, 2018, Porcelain, china paint, luster, $8 \times 10.5 \times 10.5 \mathrm{in}$. Image by KeneK Photography, courtesy of Wexler Gallery.

While Lugo wields terms "ghetto potter" and "hip-hop artist through pottery" with ease and facility, the terms bear some complexity worthy of further consideration. Initially, Lugo speaks of hip-hop as identity in so much as it implies a person of color, of street or city living, and of a lower socioeconomic status or income level. When pushed to consider how hip-hop might be more than the agglomeration of these factors, Lugo refers to the aesthetic of good enough, being resourceful, or making do as factors of life on the streets. He asks that ceramics, a field that has concerns founded in issues of craft, including ability, finesse, and technical prowess, reconsiders how this disposition prioritizes a certain way of being and doing and asks us to reevaluate the reasons why someone might approach a material or problem differently. He explains that his way of doing and making might seem amateurish or nescient but that a slapdash approach has much to do with the circumstances and context that shaped who he is. Lugo explains, "I often make hasty decisions because I'm impatient; this impatience comes from the resourcefulness of growing up in a poor neighborhood where you often have to say, 'that's good enough.'" (Eds 2017, p. 11) Here, we are asked to reconsider how notions of work, painstaking, attention, time, care, repeated practice, and even the assumption of choice in production indicate a privileging of a kind of making and of one way of being over all others. This goes beyond familiar modernist (industrialized processes) and conceptual art examinations of work, craft, and production to a postmodern or culturally situated notion of production in which modes and approaches to making indicate a certain viewpoint, positionality, or subjectivity.

This suggests that fastidiousness, time, and refinement of skill and materials are kinds of privilege and indicate the dominant culture's ability to not only recreate power through a visible aesthetic, or its visuality (Mirzoeff 2011, p. 3), but it does so through its practices. He indicates that privilege, context, and culture have much to do with aesthetics and that a hip-hop aesthetic can offer a counter-narrative to existing hegemonic cultural practices and can stimulate new approaches to making allowing for new ideas, forms, practices, and viewpoints. Furthermore, a multiplicity of voices, viewpoints, and visual approaches stands to expand cultural modes of production, engendering creative possibilities through 
cultural intersections, hybridity, and deteritorializations of cultural and physical space (visualities and 3d forms) (Deleuze and Guattari 1980).

Lugo attributes African-inspired bright colors and bold patterns, like those found in the work of contemporary artist Yinka Shonibare, to a graffiti or hip-hop aesthetic. He explains that the patterns and bold colors that Shonibare (Art in the 21st Century Producer) uses in his fabrics and that are part of Lugo's conception of a hip-hop aesthetic as "life giving or life affirming". Lugo states, "A lot of these people certainly felt inferior," and their lives are often seen as insignificant or dispensable. He claims, "being able to put your name on something and claim ownership of it was really a reaction to [that] reality." And "if you're wanting to be seen, having your name highlighted in really bright colors makes a lot of sense." (R. Lugo, personal communication, 6 June 2018)

While many have questioned hip-hop's value as cultural expression (Castleman 2012), its most notorious visual form, graffiti, plays an important role in Lugo's work. Not only can its influence be seen in his ceramic work, but Lugo also has deep connections to the practice of graffiti. Lugo claims that he didn't have the opportunity to take art classes in school and that he came to be an artist through learning graffiti with Payne (Tony Cuco) (Shulman 2014, p. 48), and that while he was growing up, he practiced graffiti art with his cousins. "I started out tagging as a graffiti artist and I don't want to lose that. A lot of the things I do are gestural, but I also choose places to be tight", Lugo admits to Brown (2017). According to Brown (2017), Lugo still uses the same tag names on his ceramics that he used as a graffiti artist. The name Robske refers to himself, while Maz refers to his brother. He has since added a third name, Ask, which Brown (2017) claims "he conferred on his wife when the two began collaborating as artists" (p. 56).

Lugo's work marries a hip-hop or graffiti aesthetic with generic-yet-ornate white pottery meant to evoke a sense of classicism and investigate cultural assumptions of the superiority (and purity) of white wares. According to Essner (2016), Lugo "is equally influenced by the history of ceramics. Harnessing the aristocratic language of porcelain, traditional forms and ornament are his point of departure" (para. 5).

These nonspecific forms made of white clay refer to pots that are of a European or Asian ceramic vernacular but that don't refer specifically back to any exact form. They look like or mimic wares that would be found in well-to-do 18th century homes or as part of the elite gentility, yet we cannot specifically pinpoint the form to a type of pot like we can with Greek pottery, where a krater has a distinct form different from an amphora of a pyxis.

Furthermore, Lugo's teapot series that includes the work titled Celia Cruz-Basquiat Teapot is the physical marrying of hip-hop's visual and musical factions in what Brown (2017) terms "bonds of community" (p. 56). In this specific body of work, Lugo places images of notable people of color on the same vessel, which effectively creates connections and relationships between the two. In the Celia Cruz-Basquiat Teapot, 2016 (Figures 11 and 12), Celia Cruz, who was a Cuban-American singer known as "la reina de salsa" (the queen of salsa) (Pearlman 2008, para. 1), is paired with neo-expressionist painter Jean-Michel Basquiat. Lugo claims an affinity to Basquiat not only because they both use crowns (a practice and connection that Lugo didn't realize until discovering Basquiat well into his college career), but also because of Basquiat's connection to hip-hop and pop culture, his intelligent take on cultural relations, and his cultural heritage. Basquiat, an American artist of Haitian and Puerto Rican descent, used recurring symbols in his work, the most recognizable being the crown which he used, according to Rodrigues (2011), to denote "kings of cool" and which has been interpreted with the help of Hooks (1994) critical look at coolness as "referring not only to glory and power but also to dehumanization - to white and nonwhite males' willingness to "commit any unjust act that will lead them to the top." (p. 36) In another similar work, Incarceration Vase, Lugo places Frank Sinatra's mug shot, taken when being charged with adultery, on the same pot as civil rights leader Martin Luther King Jr. In each of these works, we are meant to draw connections and build meaning between the two images. 


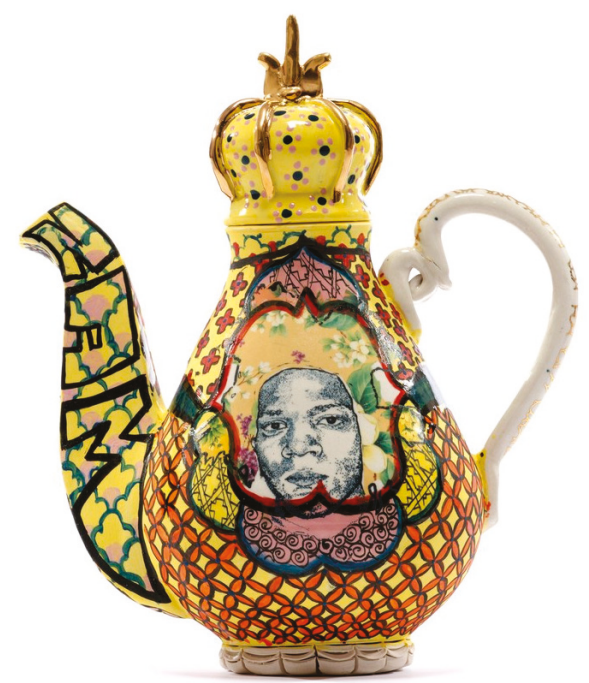

Figure 11. Basquiat/Celia Cruz Teapot, 2016 Porcelain, china paint, gold luster, $12 \times 10 \times 61 / 2$ in. Image by KeneK Photography, courtesy of Wexler Gallery.

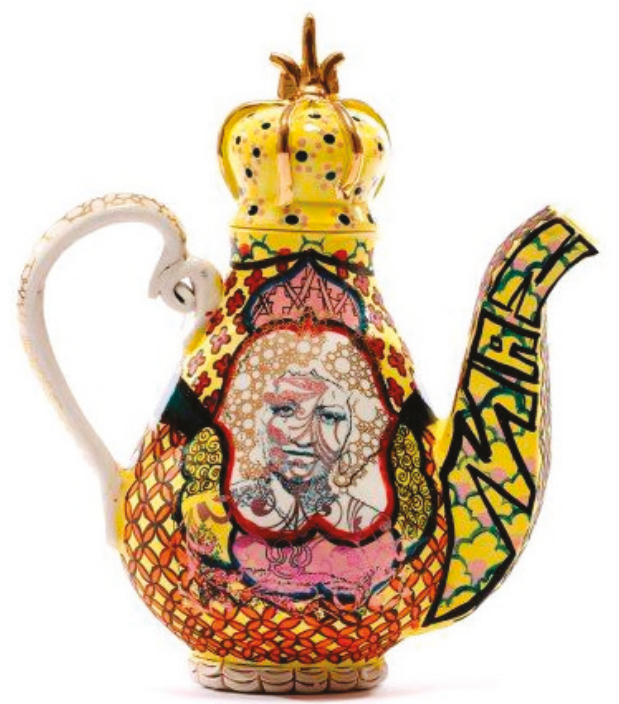

Figure 12. Basquiat/Celia Cruz Teapot, 2016 Porcelain, china paint, gold luster, $12 \times 10 \times 61 / 2$ in. Image by KeneK Photography, courtesy of Wexler Gallery.

\section{Hip-Hop, Identity Politics, and Identifying New Narratives}

Lugo explains that much of the reason that he juxtaposes the images and aesthetics of hip-hop onto white wares has much to do with a kind of reclaiming or reimagining of cultural and systemic power that has supported and propagated white hegemony and supremacy. Lugo (personal communication, 2018) explains, "The idea behind working in that way comes from this desire to put people in places where others don't think they belong or historically they haven't." (R. Lugo, personal communication, 6 June 2018) 
Lugo (2018) states, “And so I think some of the tenets of hip-hop are this idea of empowerment, of freedom, of ownership and creating our own identity separate from something that's been given to us by, you know, an Anglo history. And so, I think ceramics and the way that I'm working right now is just one facet to that." (R. Lugo, personal communication, 6 June 2018) Lugo (2018) continues, "Hip-hop is also a reaction to the Hispanic and black experience in the United States. ... my work's a section of that and while it's made out of clay it's really just another way to tell that story." (R. Lugo, personal communication, 6 June 2018)

Brown (2017) sees the work as a statement of Lugo's identity, stating, "These are straightforward, even raw, declarations of identity." While there is much of Lugo in these works, there is also more to it than a mere singular statement of self. Indeed, Lugo makes works that feature his likeness (A Queen and I, 2018) (Figure 13) or that take on issues that he personally experiences (The Day my Belt Broke, 2013), but many more of his works deal in identity through engagement with concepts surrounding identity politics, questions of larger cultural inclusion, and an examination of systems of power that historically have prevented minority cultures from being in the position of power to tell their stories. Lugo's work reimagines these structures and not only tells his story but seeks to retell and reimagine larger cultural narratives, to create space for multiple voices, and to provide underprivileged and underrepresented peoples opportunities to be seen and to see through art experiences.

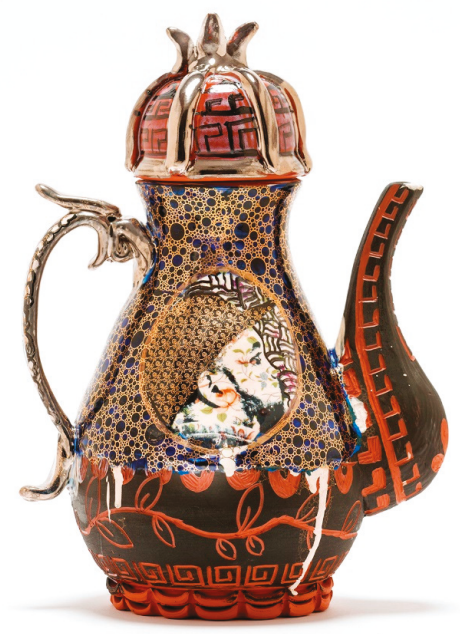

Figure 13. A Queen and I, 2018, Terra cotta, china paint, luster, $8 \times 6 \times 111 / 2$ in. Image by KeneK Photography, courtesy of Wexler Gallery.

In this way, Lugo's work is not only part of the hip-hop tradition through the aesthetic connections discussed earlier, but his work also follows the hip-hop tradition of social and political awareness and the telling of minority perspectives and retelling or recasting of dominant narratives through the perspective of young, black rappers, many of whom began as underground elements and gained public notoriety as through commercial acceptance. Certainly, Chuck D, front man for Public Enemy, is often quoted as describing rap music as "black CNN" (Neal 2012, p. 35). Speaking to the variety of voices coming out of hip-hop and black culture in general, Forman (2012) explains the inherent politics of hip-hop. He states:

These various points of conflict have an undeniably ideological character as well, especially when we consider the different values and perspectives that emerge around issues of 
race and class as well as such factors as age, gender, or locale. Indeed, it is sheer folly to conceive of hip-hop outside of an ideological analytical mindset, since the genre of rap music and the practices associated with B-boying and graffiti are each capable of articulating counter-hegemonic intentions and have done so throughout hip-hop's three decades of existence. (p. 11)

Given this, we might conclude that not only does Lugo's work embrace the vernacular of hip-hop, but that Lugo himself and the ideas that his ceramic work and that his leadership in the ceramics field embody are also hip-hop-meaning that they work to question, call attention to, and disrupt white hegemony. Admittedly, Lugo sees the leadership of Colin Kaepernick as part of the expanded field of hip-hop (to borrow an art term). As touched on earlier, Kaepernick launched onto the national political stage as a leader or symbol of the Black Lives Matter movement and as someone working to counter notions of white supremacy and question power structures and harmful practices of implicit bias. Lugo, also a leader for people of color within the ceramics field, embodies this expanded sense of hip-hop, creating a space for the voices of people of color, questioning and celebrating cultural differences, and expanding and stretching the field to include new ideas and new membership.

\section{Hip-Hop Practices beyond Pottery}

While we could characterize much of Lugo's work within the field of contemporary pottery, his practice is not singular. His work pushes beyond the neat and tidy confines that categorization in art conventionalizes. In addition to the widely well-received, remarkable, and layered ceramic works, Lugo engages in other forms of making. While Lugo's practice is varied, much of it engages with the patois of hip-hop. Of course, this is true of his early work as a graffiti artist, yet there are other practices that explore this vocabulary. Lugo engages with the performative aspect of his identity through the practice of spoken word poetry and rap, which he often employs during his artist talks. Lugo's 2015 NCECA Emerging Artist speech and the video performance work Ghetto is Re. source. ful exemplify this practice. This work seems somewhere between impromptu rap performance, rap video, confessional, and performance art. According to Essner (2016), Ghetto is Resourceful is "filmed in an abandoned lot near his (Lugo's) childhood home", "illustrates the ideas behind" his ceramic work, and "is a raw self-portrait". (para. 4) Here, Lugo uses the mediums of video, found objects, and spoken word in order to tell his story and illustrate the skillfulness and thrifty providence he attributes to growing up in the ghetto as a person of color.

In addition to this confessional and highly personal work, Lugo considers his civic, social, and educational work to be the most significant work that he does. In an interview granted as part of being named 2018 artist of the year, Lugo admits:

my other passion ... is introducing clay to every nook and cranny of the black and Hispanic communities, which don't often have access to clay ... what I really want to do is become irrelevant. I want so many people of color to become ceramic artists that I am just one grain of sand in a sunny beach where we all go play. (p. 9)

In addition to his work as an Assistant Professor of Ceramics at Tyler School of Art Temple University, Lugo has participated in an array of civic and educational programs. Lugo has participated in Bread KC and empty bowls while a student at the Kansas City Art Institute (Schulman 2014, p. 51). He has exhibited work and given a public talk with photographer Richard Ross in order to draw attention to the need for creative education as part of the juvenile justice system (Lugo 2013) and he has worked with The Clay Studio's clay mobile to help to bring ceramic-making opportunities to children in Philadelphia. In summer 2018, Lugo worked with 15-20 high school students through Artspace, New Haven's apprenticeship program, and he paired with The Clay Studio in a community project called “Making Place Matter" (Eds 2017, p. 10).

While the connection between these social, civic, political, and educational works and hip-hop may not be at first glance clearly related, hip-hop has a long history of this kind of involvement. 
While Kitwana (2012) describes a rift between the new Black youth culture of the hip-hop generation and the previous generation of civil rights and Black power based on public images of blackness, she explains a commonality between the two in their investment in community. Kitwana (2012) states:

Careful examination reveals that some rappers individually and collectively have consistently responded to issues important to this generation. The response may not have always been effective, or even politically correct, but they are the types of activities that have galvanized community-building efforts. The extent of the impact seems to be directly proportionate to the degree that such efforts work themselves into the fabric of hip-hop's cultural movement. (p. 458)

Even though Lugo's goal is equal access to opportunities to engage in rich materials and methods of expression like clay, and he claims that his pots and creative work are ancillary to the real work of creating opportunities for others, we might look at the pots themselves as operating in an activist manner. They seem to function in a similar way to rap from more socially-conscious or political rappers, like Public Enemy, KRS-One, Mos Def, Common, or Immortal Technique, whose work confronts political and social issues facing communities of color. Lugo's ceramics also do this work, yet his ceramics seem more palatable than other popular forms of minority expression, including political hip-hop, graffiti, and gangster rap. While there are some who oppose Lugo's politics and viewpoint, the larger ceramic field has, for the most part, embraced his work and the work seems not to have sparked the same controversies that hip-hop, gangster rap, and graffiti initially did and often still do today (Baldwin 2012; Castleman 2012; Chung 2015).

I submit that while Lugo's ceramic work does much to elevate minority culture and create a more inclusive art community, in doing so, it has shed some of the more difficult, objectionable, or confrontational parts of hip-hop practice. Specifically, the work refrains from the use of explicit imagery, language, and violence, and much of what is broached is done so through inference, allusion, metaphor, and portraiture rather than through brute depictions, head-on confrontation, or (threatening) anger. We might also conclude that Lugo's work contains a bit of what Kester (2013) refers to as the "ironic detachment" of contemporary work created in relationship to contemporary theory (p. 115). His work is cerebral and makes vernacular or textual connections between cultures and relies on art's recursive self-referentiality. Rather than engage with the messiness of cultural confrontation, it opts for what Kester (2011) calls "tactical withdrawal into the protected field of the text" (p. 45).

In order to elevate the conversation, stay above the fray, and avoid piling onto the media's negative stereotypes of African Americans and other people of color, Lugo's work omits many of the subversive or unsavory markers of hip-hop and graffiti, such as: Aggressive language, expletives, depictions of violence and murder, dysfunction of the black family, misogyny, and homophobia (Baldwin 2012, p. 230). Meanwhile, as part and parcel to its reception in the contemporary gallery scene, the work seems to encourage commodification, notions of personal property, and cultural elitism not unlike the very social, political, and cultural structures that Lugo's work examines. For instance, works from Lugo's Stunting series sell for between five thousand and seven and a half thousand dollars each. We might ask if those patrons and viewers who consume, support, and celebrate Black culture also fully consume, understand, and adopt Black social consciousness. We might also ask if the underrepresented and underprivileged whom Lugo seeks to provide opportunities to see and be seen through art making are indeed able to access, view, and benefit from his works.

It seems that Lugo adheres to and his main interest is in the notion expressed by First Lady Michelle Obama during the 2016 presidential campaign (Abcarian 2016) and reiterated in the name of one of his pots, When They Go Low We Go High, 2018 (Figures 14 and 15), although it is unclear if they refer to a "they" that Lugo distances himself from in order to cast off the less desirable aspects of minority culture or if "they" refers to those that would perpetuate and profit from misrepresentations of minority culture. 


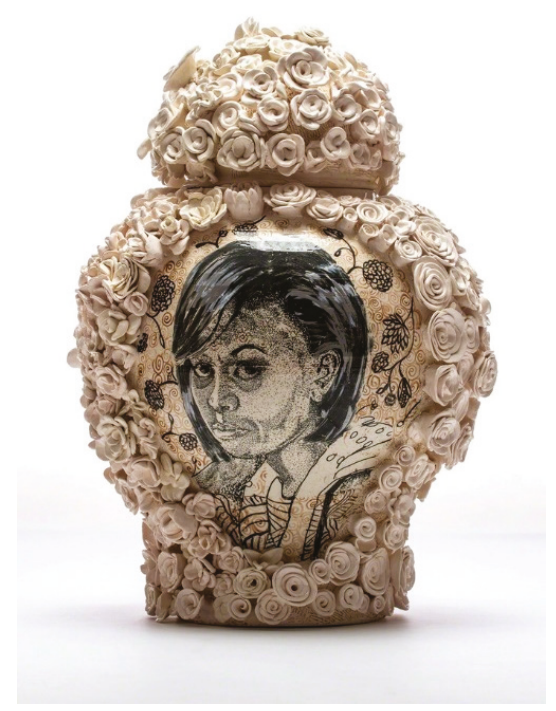

Figure 14. When They Go Low We Go High, 2018, Porcelain, China Paint, Luster, $25 \times 16 \times 14$ in. Image by KeneK Photography, courtesy of Wexler Gallery.

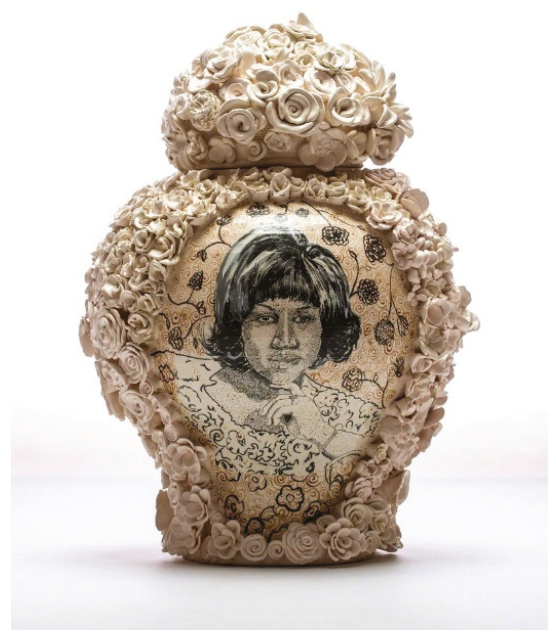

Figure 15. When They Go Low We Go High, 2018, Porcelain, China Paint, Luster, $25 \times 16 \times 14$ in. Image by KeneK Photography, courtesy of Wexler Gallery.

\section{Implications for Visual Culture and Art Education}

The ways that Lugo's work and practice intersect with hip-hop present many rich opportunities for critical discussion, involving a variety of visual cultures. Specifically, his work presents the opportunity to explore the field and cultural history of ceramics and to look more closely at hip-hop and minority culture and history. It presents the opportunity to explore the complexities and contradictions between traditional art making and the art market and activist, social consciousness-raising as part of the art world and hip-hop. On the whole, the study of Lugo's visual culture production and practices holds vast potential to engender meaningful, critical dialogue about the structures of art, culture, and power. 
Therefore, the study of Lugo's work would provide rich fodder for any multicultural or visual culture art education program that explores intersections of images, making, culture, power, race, and class.

Furthermore, Lugo is very much aware of art education's role in his practice and is quite interested in the ways that the theories of renowned art educator Olivia Gude intersect with his work. Gude is best known for her work with the Spiral Workshop at the University of Illinois at Chicago ${ }^{1}$ and for her conception of postmodern principles of art. Gude (2004) reinvents art education's traditional vernacular, the (Modernist) elements and principles of design, in order to account for new art making practices embraced by multicultural and contemporary artists. In particular, Lugo speaks about the way that such juxtaposition enlivens his work. He explains, "I think what's often jarring about what someone like me does is that you wouldn't expect hip-hop or graffiti to be placed on to pottery, or for those two worlds to exist in one." (R. Lugo, personal communication, 6 June 2018)

Likewise, Forman (2012) explains:

The evolution of hip-hop corresponds with cultural theorist Raymond Williams's observation that the process of "formal innovation" is gradual, and, while "residual" cultural practices from prior eras continue, new "emergent" cultural forms and practices may arise that challenge or disrupt the culture dominant. (p. 9)

Although not specifically mentioned by Lugo, his work involves many more of Gude's postmodern principles, which are "hybrids of the visual and conceptual" (Gude 2004, p. 8) and include appropriation, hybridity, layering, recontextualization, interaction of text and image, gazing, and representin' in addition to juxtaposition (Gude 2004, pp. 9-12). These principals not only describe contemporary art, but they are particularly postmodern in their ability to "participate in the unfolding of contemporary culture" and "to reflect on cultural issues related to self and society" (p. 8). In other words, the postmodern principles allow students to explore and deconstruct the visual as it creates and expresses meaning, culture, and power.

The notion that the visual, meaning that which is seen, creates meaning, culture, and power is known as visuality (Mirzoeff 2011) and visual culture art education is an art education that explores and deconstructs visuality, questions what it is to look and be the looker, or to be seen or represented, and deconstructs visual hierarchies in order to engender multiple knowledges, cultures, and ways of being. Visual culture art education also deals in how "we represent, make meaning, and communicate in the world around us (through the visual)" (Sturken and Cartwright 2004, p.1). Thus, much of what visual culture art education explores is also the expanded study of all things visual rather than the elitist study of the highest cultural standards, which often characterizes the study of fine art. Freedman (1997) claims "education should focus not only on the distribution of factual information, high culture, and students' own production, but also should include discussions of the popular visual culture that influences student knowledge." (p. 46) Thus, the study of Roberto Lugo's work not only offers an opportunity to engender discussions of popular visual culture, but his hip-hop aesthetic asks students to consider notions of visuality and to create and elevate new and multiple knowledges, cultures, and ways of being and making.

As an educator, Lugo's practice is somewhat different from established, school visual culture practices where students learn to read and speak back against the messages and meanings in images and other visual entities (Darts 2006; Duncum 2000, 2002; Freedman 1994; Freedman 2003; Stuhr and Ballengee-Morris 2001; Polaniecki 2006; Plummer-Rohloff 2006; Tavin 2003; Tavin and Anderson 2003; Taylor 2000). Unlike much of visual culture education, Lugo's artist educator practice takes on an amelioratory tone, meaning that much of what he does is to provide opportunities and experiences for people who previously would not have had the privilege. During Lugo's work with Artspace in New Haven, Connecticut Lugo facilitated the creation of ceramic rest in peace murals, in which

1 https://naea.digication.com/Spiral/Spiral_Workshop_Theme_Groups/published. 
twenty young adults paid homage to their heroes (Duff 2018). Here, Lugo's pedagogical approach is like that of an activist who provides opportunity and access and through them, his students are given a voice with which to speak back at dominant discourse. This approach provides one more possible pedagogical approach for empowering students to visually speak truth to power.

Roberto Lugo's work not only challenges and juxtaposes cultural practices, but the conversation and concepts that arise from the intersection of these cultural practices is healthy fodder for examinations of visual culture both inside and outside the art classroom. While Lugo's work aims to raise social consciousness through its content and form, its examination and employment of visual vernacular poses interesting questions that ultimately engender rich, critical dialogue. Classrooms that engage with the form, ideas, and concepts that Lugo employs stand to develop a more critical and culturally aware understanding of the possibilities and power of visual culture, art, and dialogue.

Funding: This research received no external funding.

Conflicts of Interest: The author declares no conflict of interest.

\section{References}

Abcarian, Robin. 2016. Michelle Obama's Stunning Convention Speech: When They Go Low We Go High. Los Angeles Times. July 25. Available online: www.latimes.com/politics/la-na-pol-michelle-speech-20160725snap-story.html\# (accessed on 30 September 2018).

Art in the 21st Century (Producer). 2009. Yinka Shonibare in "Transformation" Season 5 (DVD). Available online: https: / art21.org/watch/art-in-the-twenty-first-century/s5 /yinka-shonibare-mbe-intransformation-segment/ (accessed on 30 September 2018).

Baldwin, Davarian L. 2012. Black empires, white desire: The spatial politics of identity in the age of hip-hop. In That's the Joint: The Hip-Hop Studies Reader. Edited by Murray Forman and Mark Anthony Neal. New York: Routledge, pp. 435-37.

Bisson, Terry. 2009. John Brown: 150 years after Harpers Ferry. Monthly Review: An Independent Socialist Magazine 61: 37-39. [CrossRef]

Brown, Glen. R. 2006. Teaching ceramics history: Glen R. Brown gives some reflections on his experience teaching ceramics art history. Ceramics Technical 23: 37-42.

Brown, Glen. R. 2017. Roberto Lugo: Undermining indifference. Ceramics Monthly 46: 54-57.

Castleman, Craig. 2012. The politics of graffiti. In That's the Joint: The Hip-Hop Studies Reader. Edited by Murray Forman and Mark Anthony Neal. New York: Routledge, pp. 14-21.

Chung, Sheng Kuan. 2015. Media/visual literacy art education: Sexism in hip-hop music videos. Art Education 60: 33-38. [CrossRef]

Clark, Garth. 2007. Fortress ceramica: Answered prayers. Ceramic Art and Perception 70: 102-4.

Darts, David. 2006. Head Game\$TM: Engaging popular vi\$ual@ulture. In Visual Culture in the Art Class: Case Studies. Edited by Paul Duncum. Reston: NAEA, pp. 99-108.

De Waal, Edmund. 2016. The White Road: Journey into Obsession. London: Picador.

Deleuze, Gilles, and Felix Guattari. 1980. A Thousand Plateaus: Capitalism and Schizophrenia. Minneapolis: University of Minnesta Press.

Duff, C. [Screen Name]. 2018. Roberto Lugo: Soil and Site [Video File]. Available online: https://vimeo.com/ 297334361 (accessed on 26 October 2018).

Duncum, Paul. 2000. Deconstructing media images of postmodern childhood. In Real World Readings in Art Education: Things Your Professors Never Told You. Edited by Dennis Fehr, Kris Fehr and Karen Keifer-Boyd. New York: Farmer Press, pp. 29-34.

Duncum, Paul. 2002. Visual culture art education: Why, what and how. International Journal of Art \& Design Education 21: 14-23.

Eds. 2017. Roberto Lugo: Ceramic Artist of the Year. [Special issue Supplement Yearbook]. Ceramics Monthly, 8-12.

Essner, Elizabeth. 2016. Roberto Lugo Is Changing the World One Teapot at a Time. Modern Magazine, March 29. Available online: http://modernmag.com/roberto-lugo-is-changing-the-world-one-teapot-at-a-time/ (accessed on 30 September 2018). 
Forman, Murray. 2012. Hip-hop ya don't stop: Hip-hop and historiography. In That's the Joint: The Hip-Hop Studies Reader. Edited by Murray Forman and Mark Anthony Neal. New York: Routledge, pp. 9-12.

Freedman, Kerry. 1994. Interpreting gender and visual culture in art classrooms. Studies in Art Education 35: 157-70. [CrossRef]

Freedman, Kerry. 1997. Critiquing the media: Art knowledge inside and outside of school. Art Education 50: 46-51. [CrossRef]

Freedman, Kerry. 2003. Teaching Visual Culture. New York: Teachers College Press.

Gregory, Sean. 2017. Colin Kaepernick. Time 190: 100-3.

Gude, Olivia. 2004. Postmodern principles: In search of a 21st century art education. Art Education 57: 6-14. [CrossRef]

Gupta Wiggers, Namita. 2013. Navigating Whiteout Conditions: 2013 Distinguished Lecture. Paper presented at 2013 NCECA Conference, Houston, TX, USA, March 20-23.

Hooks, Bell. 1994. Outlaw Culture. New York: Routledge.

Kester, Grant. 2011. Temporary coalitions, mobilized communities, and dialogue as art. In What We Made: Conversations on Art and Social Cooperation. Edited by Tom Finkelpearl. Durham: Duke University Press, pp. 114-31.

Kester, Grant. 2013. The One and the Many: Contemporary Collaborative Art in a Global Context. Durham: Duke University Press.

Kitwana, Bakari. 2012. The challenge of rap much from cultural movement to political power. In That's the Joint: The Hip-Hop Studies Reader. Edited by Murray Forman and Mark Anthony Neal. New York: Routledge, pp. 452-61.

La Force, Thessaly. 2015. The European Obsession with Porcelain. The New Yorker. November 11. Available online: https://www.newyorker.com/books/page-turner/the-european-obsession-with-porcelain/amp (accessed on 30 September 2018).

Lopez, Alfr. 2005. Introduction: Whiteness after empire. In Post-Colonial Whiteness: A Critical Reader on Race and Empire. Edited by Alfred Lopez. Albany: SUNY Press, pp. 1-30.

Lugo, Roberto. n.d. Statement. Available online: http:/ / robertolugostudio.com/ (accessed on 30 September 2018). Mirzoeff, Nicholas. 2011. The Right to Look. Durham: Duke University Press.

Neal, Mark Anthony. 2012. "The message": Rap, politics, and resistance. In That's the Joint: The Hip-Hop Studies Reader. Edited by Murray Forman and Mark Anthony Neal. New York: Routledge, pp. 435-37.

Pearlman, Ellen. 2008. Azucar! Celia: The Life and Music of Celia Cruz at the New World Theater. Brooklyn Rail. March 7. Available online: https://brooklynrail.org/2008/03/music/azcar-celia-the-life-and-music-ofcelia-cruz-at-the-new-world-theater (accessed on 30 September 2018).

Plummer-Rohloff, Rebecca. 2006. Beyond the circus: Grounding a visual culture pedagogy. In Visual Culture in the Art Class: Case Studies. Edited by Paul Duncum. Reston: NAEA, pp. 65-71.

Polaniecki, Sherri. 2006. Teaching through TV: Transformative encounters with constructed reality. In Visual Culture in the Art Class: Case Studies. Edited by Paul Duncum. Reston: NAEA, pp. 39-46.

Rodrigues, Laurie. 2011. SAMO® as an escape clause: Jean-Michel Basquiat's engagement with commodified American Africanism. Journal of American Studies 45: 227-43. [CrossRef]

Schulman, Blair. 2014. Roberto Lugo: Not fearing the message. Ceramic Art and Perception 98: 48-51.

Stapleton, Alex (Producer), Thibuat de Longeville, and Lisa Leone (Directors). 2005. Just for Kicks [Motion Picture]. New York: CAID Productions Program 33.

Stuhr, Patricia, and Christine Ballengee-Morris. 2001. Multicultural art and visual culture in a changing world. Art Education 54: 6-13.

Sturken, Marita, and Lisa Cartwright. 2004. Practices of Looking: An Introduction to Visual Culture. New York: Oxford University Press.

Tavin, Kevin. 2003. Wrestling with angels, searching for ghosts: Toward a critical pedagogy of visual culture. Studies in Art Education 44: 197-213. [CrossRef] 
Tavin, Kevin, and David Anderson. 2003. Teaching (popular) visual culture: Deconstructing Disney in the elementary art classroom. Art Education 56: 21-35.

Taylor, Pamela. 2000. Madonna and hypertext: Liberatory learning in art education. Studies in Art Education 41: 376-89. [CrossRef]

(c) BY

(C) 2018 by the author. Licensee MDPI, Basel, Switzerland. This article is an open access article distributed under the terms and conditions of the Creative Commons Attribution (CC BY) license (http:/ / creativecommons.org/licenses/by/4.0/). 


\title{
Hip Hop Pedagogy as Culturally Sustaining Pedagogy
}

\author{
Melanie L. Buffington * and Jolie Day \\ Department of Art Education, Virginia Commonwealth University, Richmond, VA 23284, USA; \\ dayj3@mymail.vcu.edu \\ * Corresponding: mbuffington@vcu.edu; Tel.: +1-804-8283805
}

Received: 21 August 2018; Accepted: 28 November 2018; Published: 3 December 2018

\begin{abstract}
This paper argues that Hip Hop Pedagogy is a version of Culturally Sustaining Pedagogy and should be a part of art education. Further, we believe that when exploring Hip Hop Pedagogy, teachers need to reference the work of Black female and non-binary artists. After an overview of Hip Hop Pedagogy and Culturally Sustaining Pedagogy, we argue that these approaches should be a consistent part of art education. Through the work of contemporary visual artist and DJ, Rozeal, we offer suggestions for art educators about how they might transition their practice to embrace some aspects of Hip Hop Pedagogy. Specifically, through sampling and the distinction of cultural appreciation versus appropriation, we believe that art educators can change their practice to make their teaching more relevant to their students and to contemporary culture.
\end{abstract}

Keywords: Hip Hop pedagogy; Rozeal; culturally sustaining pedagogy; art education; culture

\section{Introduction}

In this paper we argue that Hip Hop Pedagogy is an extension of culturally relevant pedagogy (CRP) as originated by Ladson-Billings (1995) and Gay's (2000) work in culturally responsive teaching. Paris (2012) built upon their ideas to develop his idea of culturally sustaining pedagogy (CSP). Rather than using Hip Hop as a hook or as social currency (Kuttner 2016), we argue that CSP can be used in the arts to teach about artists from the genre, going beyond cyphers and rap battles about academic subjects. We argue that using Hip Hop as a hook toward enticing students into learning about traditional topics de-legitimizes Hip Hop itself as an important cultural and artistic form and promotes superficial understandings of cultural practices. Further, we argue that many calls to include Hip Hop Pedagogy focus on male artists and that the practice needs to include Black and Brown women, women identifying, and gender minority artists from Hip Hop. The call for this special issue includes the names of five individual artists, Jay- $Z$, Nas, Kanye West, Rick Ross, and Lil Wayne, all male. Thus, we chose to focus on the work of a Black female contemporary artist and DJ, Rozeal, and the implications for her work in art education settings.

We came to have the discussions that inform this paper through a graduate class, Curriculum Development and Evaluation, in which Jolie was a student and Melanie was the professor. As a part of this class, we addressed culturally relevant and culturally sustaining pedagogies. Throughout the course, we emphasized the diversity of learners and educational settings. In addition to numerous journal articles, we also read Emdin (2016) For White Folks who Teach in the Hood ... and the Rest of Y'all Too: Reality Pedagogy and Urban Education. Through conversations we came to see the need for more examples of Hip Hop Pedagogy, informed by Black feminism (Brown and Kwakye 2012; Peoples 2008), in art classrooms. Our collaboration on this paper resulted from Jolie's research into Rozeal, a contemporary painter who remixes traditional Japanese woodblock prints with contemporary Hip Hop imagery while questioning cultural appropriation, globalization, and representation. We saw similarities between Paris (2009) and Emdin's ideas (Emdin 2016) and Rozeal's work and believe that 
the work of Black women artists needs to be as central to the discussion of Hip Hop Pedagogies as the work of male artists.

\subsection{Personal Connections (Positionality)}

\subsubsection{Jolie}

I am a graduate student, a White woman, who grew up hearing Hip Hop on the radio. My father loves jazz and that music was a prominent part of my home culture, but Hip Hop was not. I first connected with Hip Hop in the sixth grade listening to a friend's copy of "3 Feet High and Rising" by De La Soul (1989). De La Soul's sampling of jazz on this album was my entry point to Hip Hop. I started listening to Hip Hop more actively as a teenager, not always understanding the complexities of the subject matter or lived experiences that artists express. The energy of the music and the cadence of voices in connection to the baseline drew me in. I am not a Hip Hop expert, and currently listen to a blend of mainstream Hip Hop, old school, and current indie artists, including Princess Nokia, Angel Haze, and Mykki Blanko.

\subsubsection{Melanie}

I am a White woman with 23 years of teaching experience who grew up during the 1980s and 1990s. In my middle school and high school days, Hip Hop and rap artists including Run DMC, Salt-N-Pepa, NWA, Queen Latifah, and others were popular and I listened to their music. While I am not a serious Hip Hop fan or expert, I notice how positively students respond to ways of teaching that relate to their interests and contemporary culture. For instance, I have seen students respond in a far more visceral manner to contemporary visual artists whose works relate to the students' cultural backgrounds than to historic artists. Thus, I have a deep interest in CSP and see Hip Hop Pedagogy as one vein of CSP.

\subsubsection{Our Collaboration}

Neither of us (the authors) are women of color and we are aware of our positionality and, at times during this writing process, felt like "posers." At the same time, we fully believe that White people need to do the work of dismantling structural racism and it is not right or fair to expect scholars of color to do the heavy lifting while the White folks stand by and say, "It's so hard." Our job is to be allies and to recognize and honor our limitations while we continually strive to do better and contribute to the process of building a more equitable education system. This article is one of our attempts to be allies, to contribute to the art education literature around CSP, and to educate ourselves during the writing process.

\section{Working Understanding of Hip Hop Culture}

It is important to establish a working definition of Hip Hop to aid an understanding of Hip Hop Pedagogy. Hip Hop originated in the early '70s in the Bronx with block parties thrown by DJ Afrika Bambaataa and Kool Herc, a Black DJ from Jamaica (Jeffries 2014). Hip Hop spread quickly as a community effort made under the specific contexts of working-class Black and Latinx youth in New York City, and beyond during the '70s and '80s (Petchauer 2015). The economic and social situations experienced by those in New York were not isolated, as economic shifts moved away from manufacturing, leaving many working and middle-class families under-employed and unemployed (Jeffries 2014).

Hip Hop was also a social movement that promoted constructive dialogue, and responded to racial and class discrimination, lack of opportunity, and chronic poverty, as well as a resistance to intensifying gang culture in New York (Hoch 2006; Peoples 2008). Originally seen as a recreation and social space, Hip Hop represented a " ... resistance to social marginalization," and gradually developed as an active form of protest against institutional oppression (Peoples 2008, p. 23). Afrika 
Bambaataa founded the Universal Zulu Nation, a community organization that promoted peace between gangs and local residents (Morgan and Bennett 2011). Bambaataa, among others, believed in upholding equality, working against racial divides and hierarchies (Morgan and Bennett 2011).

With its Africanist aesthetics, rhythm, and layered meaning within lyricism, Hip Hop soon spread globally (Fernandes 2003). Transnational Hip Hop becomes potentially problematic when non-Black appropriations of Hip Hop do not address the racial dimensions, or cultural hybridity of Hip Hop (Fernandes 2003). Fernandes (2003) examines the development of Hip Hop in Cuba, that Afro-Cuban youth use Hip Hop as a mode of creative expression that addressing historical and racial conditions, providing critiques of capitalism, and advocating for social justice. Noting this, Fernandes (2003) stresses the importance of not idealizing transnational Hip Hop that disrupts convention as always justice oriented. When addressing any dimension of Hip Hop, it is important to avoiding totalizing statements, or generalizing assumptions.

Hip Hop has multiple components that are important to highlight, as often the genre is simplified to rapping, and dance which can "exclude potential and actual sites of resistance within hip-hop occurring outside rap" (Peoples 2008, p. 23). For the purposes of this paper, we consider the original four elements under the umbrella of Hip Hop: "break-dancing, DJ-ing, graffiti art, and rapping" (Peoples 2008, p. 23). The definition of Hip Hop is constantly evolving, and has more recently been expanded to include: “(a) Breakin', (b) Emceein', (c) Graffiti Art, (d) Deejayin', (e) Beatboxin', (f) Street Fashion, (g) Street Language, (h) Street Knowledge, and (i) Street Entrepreneurialism" (Bridges 2011, p. 326). This understanding acknowledges that definitions of Hip Hop are fluid, non-homogenous, and continually changing.

\section{Defining Hip Hop Pedagogy}

Hip Hop Pedagogy acknowledges the genre as an art form that may be more culturally relevant to many students than a Eurocentric curriculum. Teaching a curriculum informed by Hip Hop might help counter the problem Bridges (2011) describes as the ways traditional curriculum does not value the unique lived experiences of students of color and perpetuates institutional oppression. One focus of Hip Hop Pedagogy is cyphers, which Levy et al. (2017) describe as

highly codified yet unstructured practices where youth who identify with hip-hop culture information exchange in the form of raps or dance. (Note: A cipher represents something that is cyclical, such as in freestyle rapping where each participant in the circle takes turns after the other). (p. 104)

Cyphers can function as a means for all youth to succeed in addressing their thoughts and feelings (Levy et al. 2017). However, without ground rules that emphasize mutual respect and acceptance for all members, cyphers can reproduce practices that exclude queer youth, young women, and young men who do not identity as Black (Paris and Alim 2014). While cyphers are important, they represent just one aspect of a Hip Hop Pedagogy.

Petchauer (2015) outlines the second wave of Hip Hop Pedagogy describing Hip Hop as an aesthetic practice, and tool of research that might be used to study issues, such as urban education. Alim (2011) describes this method as hiphopography, " ... an approach to the study of Hip Hop culture that combines the methods of ethnography, biography, and social and oral history" (Alim 2011, pp. 969-70). Hiphopography discourages distinctions of "researcher" and "researched" that might be associated with ethnography (Alim 2011).

Hiphopography can be used as a framework, applying Hip Hop pedagogy to addresses specific issues in an educational setting (Petchauer 2015). The outcomes could include using cyphers, elements of activism, and promoting leadership skills that connect to social justice pedagogies (Petchauer 2015). It is important to note that every student of color does not relate to Hip Hop, nor does it encompass the entirety of young person's experience (Jeffries 2014). Applying specific outcomes of educational 
practices informed by Hip Hop Pedagogy requires using multiple aspects of Hip Hop, and might give students tools and a framework, applying this pedagogy to educational challenges (Petchauer 2015).

Teaching the history of Hip Hop, and creating spaces for youth of color to be counterstorytellers, going beyond exclusively using cyphers in a Hip Hop based curriculum. An example of an organization that more fully enacts aspects of Hip Hop is Project Hip Hop, a non-profit based in Boston (Kuttner 2016). Teenage participants attend afterschool programs where they assume positions as counterstoryteller (Kuttner 2016). A counterstoryteller is someone who creates narratives that "... challenge dominant conceptions about Youth of Color and their communities, uncover marginalized stories of oppression and resistance, and offer transformative visions of change" (Kuttner 2016, pp. 542-43). Project Hip Hop functions as a community center that provides space for young people to amplify their artistic voices, earn stipends as organization leaders, and participate in programming, such as theater, while receiving credit at a local community college (Kuttner 2016).

\section{Outlining/Defining Culturally Sustainable Pedagogy}

Paris (2012) is widely credited with developing the theory of CSP that is part of a tradition of asset-based pedagogies (Kuttner 2016). Paris built upon the earlier groundbreaking work of Ladson-Billings (1995) and her theory of culturally relevant pedagogy (CRP), which promotes that teachers use the culture of students as a way to make learning relevant to them. Paris questioned if Ladson-Billings' ideas of relevance went far enough to honor the language, literacies, and cultural practices of communities systematically oppressed. Paris writes, "Culturally sustaining pedagogy seeks to perpetuate and foster-to sustain-linguistic, literate, and cultural pluralism as part of the democratic project of schooling" (p. 93). Paris extended Ladson-Billings' ideas and argues that teachers need to go beyond making schooling relevant and also work to sustain students' cultures, not merely use them as a hook to build student interest. CSP also continues the tradition from CRP of viewing students as having knowledge and recognizing their cultures and cultural identities as important, meaningful, and worthy of study in classrooms. A pivotal part of both CRP and CSP is the shift away from deficit-based thinking that emphasizes what is "wrong" with students and communities of color, to an asset-based mindset that works to recognize, honor, and sustain the cultures of students is a pivotal part of CSP. Paris (2012) also points out that a goal of deficit approaches was to, "eradicate the linguistic, literate, and cultural practices many students of color brought from their homes and communities and to replace them with what were viewed as superior practices" (p. 93).

\subsection{Evolving CSP Practices}

An important aspect of CSP that clearly relates to art education is the goal of centering education outside of White middle class heterosexual male norms and values (Paris and Alim 2014). In an art classroom, this would require teachers to carefully rethink the artists and artistic practices they teach as well as their own pedagogical strategies. Teachers might make significant changes to the artists they address, attending to equity and representation issues to ensure that all their students see themselves represented in the curriculum. Further, CSP encourages teachers to recognize and honor the validity, and increasingly important ability to speak outside of Dominant American English (Paris and Alim 2014). From an artistic perspective, this might include moving beyond the traditional language of elements and principles of art and adopting Gude (2007) principles of possibility and going beyond these to develop locally-relevant principles within the classroom or community.

Another advocate of CSP, Paul Kuttner, adds to the arguments Paris advances and points out that we need to think of CSP practices in relation to civic engagement and cultural practices as well. Kuttner encourages analyzing detrimental practices within specific cultural contexts, as well as in the dominant culture (Kuttner 2016). Within the arts, we might think of how women and people of color were historically excluded from formal art training within the United States (Nochlin 1971). Now that there are no systemic formal prohibitions, we might consider the financial prohibitions that many people still face in accessing education. Further, we might investigate the work of the Guerilla Girls 
and how they document the difficulties that people of color and women face when seeking to exhibit their work.

\subsection{Hip Hop Pedagogy Informed by Art Education}

When considering this call for papers, we noted the absence of women and felt the need to make the point that as women are an important element of Hip Hop culture, they need to be represented in Hip Hop Pedagogy. Because Hip Hop has traditionally been a male dominated, heterosexual space, it has not always welcomed women, trans, femme, queer and gender minority Hip Hop artists who may defy simplistic, hyper masculine, mainstream understandings of the genre (Chung 2007; Smith 2013). Since the origins of Hip Hop, women and queer artists navigated a space that can, "often reiterate the male privilege and assumed heterosexuality of everyday life in their music, leaving Hip-Hops' women and queer people marginalized in song as they are in reality" (Smith 2013, p. 326). Numerous scholars advocate for feminism within Hip Hop (Brown and Kwakye 2012; Durham 2007), yet we were unable to locate examples of what this might look like within art education.

Brown and Kwakye (2012) note that women have been a part of Hip Hop since its origins and that their practices of playing games in public and creating dances for healing purposes like Urban Bush Women need to be acknowledged. Further, they point out how the absence of women in many histories of Hip Hop is not accidental, but the work of the "heteropatriarchy and the heteronormativity that insidiously surround Hip Hop and structure our society" (p. 2). In explaining Hip Hop feminism, Aisha Durham describes it as

a socio-cultural intellectual and political moment grounded in the situated knowledge of women of color for the post-Civil Rights generation who recognize culture as a pivotal site for political intervention to challenge, resist, and mobilize collectives to dismantle systems of exploitation. (Durham 2007, p. 306)

Hip Hop feminism focuses on how to make Black women the subject of the movement, and move away from only critiquing the misogyny of the genre (Peoples 2008). Further, Hip Hop feminists believe the medium can be used as a platform to amplify the voices and provide space for young women, trans, femme, and gender minority people of color that avoids a paternalistic, victim narrative of saving young people (Peoples 2008). Some Hip Hop feminist scholars point out an emerging push for LGBTQ+ acceptance in mainstream Hip Hop with singer/Hip Hop artists such as Frank Ocean, and Syd the Kyd (formerly of Odd Future) (Smith 2013). At the same time, other authors believe that Hip Hop promotes understanding and expressing complex identities that do not fit stereotypical, damaging roles prescribed to women of color (Hay et al. 2018, p. 5).

To bring Hip Hop Pedagogies into classrooms, the framework of CSP may be one way to critically engage with and question practices within Hip Hop that exclude others, or perpetuate discriminatory stereotypes (Paris and Alim 2014). Specifically, we agree with Hay, Farrugia and Smith (Hay et al. 2018) who believe that Hip Hop Pedagogy is a form of CSP applicable to lives of girls and women of color. Brown (2009) states “ . . hip hop feminism scholars advocate for 'using elements of hip-hop culture and feminist methodology for the purpose of transforming oppressive institutions, policies, relationships, and beliefs" (p. 7). This is where we believe there is significant potential for Rozeal's work in art classrooms.

\subsection{Teaching Rozeal's Work as Hip Hop Artist}

Rozeal is a contemporary Black female artist whose work addresses the representation of Black people and Black Hip Hop culture, and the relationship of these cultures to Japanese pop culture. It is important to note that the term 'Black culture' is a "shorthand for a complex range of practices, ideas, and discourses, never meaning one thing" (Condry 2007, p. 639). Representation is not reality, but a construct of history that passing through social, and ideological lenses (Desai 2000). Rozeal's work has evolved through the years, but her paintings from the early to mid 2000s depict figures inspired 
by ukiyo-e, woodblocks from Japan's Tokugawa era (1603-1868) which depicted 'the floating world,' and contrasts them with contemporary Hip Hop styles, with figures often appearing in black face (Abiko 2003; Condry 2007). Rozeal's work examines racial stereotypes and how cultural identity is always shifting in contemporary, global society (Powell 2012).

In 2001, after visiting Japan, Rozeal began studying the Japanese youth trends of burapan ${ }^{1}$, and ganguro $^{2}$ (Rowell 2015). These youth trends emulate the style of Black Hip Hop culture (Anderson 2007). The crossover of Hip Hop in Japanese youth culture could be, as Condry (2007) states, " . . both as a space for articulating alternative visions of Japanese identity and for providing a comparative context for thinking about hip-hop's border crossings in the United States and elsewhere" (p. 640). The Japanese presentation of Hip Hop that Rozeal experienced relies on harmful racial stereotypes, rather than exploring two intersecting cultures (Condry 2007). Rozeal's work examines the interconnectedness of our global society, the hybridization of different cultures, and the resulting potential for misrepresentation, and fetishization (Powell 2012). In an interview with Rowell (2015), Rozeal explains what she observed in Japan:

From the ages of sixteen to twenty-four they can play .... Come twenty-four or twenty-six, whatever the age is, you have to get a job. So you stop going to the tanning salon and you stop getting that afro perm and you get yourself an office job ... So what are we really talking about here? Because to me that is not blackness. Blackness isn't something you can just put on. It just is. (p. 809)

Rozeal's work reflects Black identity as a signifier, rather than an identity one can shed (Rowell 2015). Rozeal's artwork explores cross cultural exchange, and the problems associated with mimicking other cultures without understanding or appreciating the condition that comes with them (Figure 1). She addresses the history of influence between African American Hip Hop culture, and Asian cultures (Williams and Brown 2006). Condry (2007) suggests that some of the Japanese perception of Black Americans came from racist portrayals, blackface entertainment, that were first imported to Japan in the late 1880's after Japan opened to trade at the start of the Meiji Restoration in 1863 (Abiko 2003).
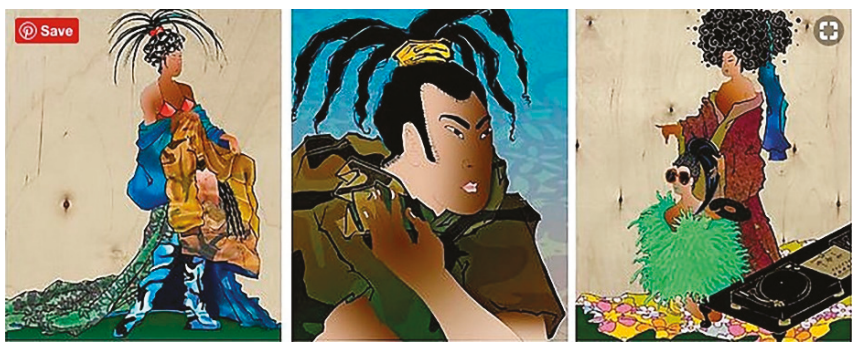

Figure 1. Rozeal. You opened my eyes man, thought I had a man, but how could I eye scan. 2008

Additionally, the term burapan stems from World War II, specific to a Japanese sex worker that would prostitute herself to Black men (Condry 2007). Having historical context might cast ganguro in a different light. Rozeal states that she was "initially pleased by the global influence and reverence of hip-hop but ultimately troubled by the Japanese youth's usually one-sided interpretation of it" (Dubois 2009, p. 44). Rozeal views this imitation not as flattery, but as a caricature based in historically damaging stereotypes (Rowell 2015).

Rozeal's work pulls from the Ukiyo-e artist Kitagawa Utamaro who created counter narratives showing women of the Tokugawa era (1603-1863) in more detail, and with more respect to their

\footnotetext{
A form of blackface Hip Hop (Rowell 2015).

A style related to burapan that has heavy use of self tanner, and a whitening around the eyes (Rowell 2015).
} 
identities (Abiko 2003; Anderson 2007). Utamaro's work differed from others of that time, featuring women in active roles and having a level of agency (Anderson 2007). Some of Rozeal's paintings mirror specific paintings by Utamaro, and like Utamaro, depict women as determiners of fashion, engaged in personal activities (Anderson 2007). Rozeal expands on the theme of women as independent subjects of the art, rather than depicting women in service to men, showing female subjects, often in quiet moments with other women (Figure 2).

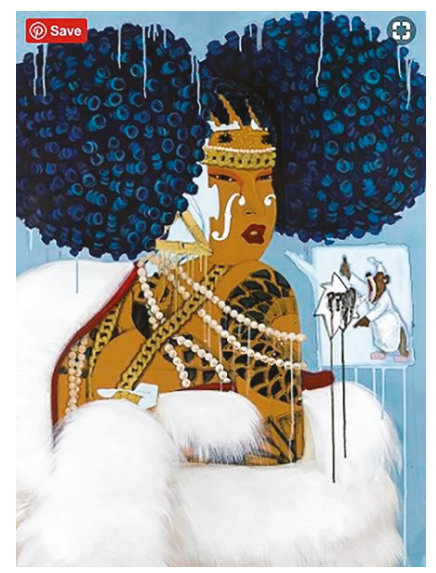

Figure 2. Rozeal. Untitled. 2016.

Rozeal samples from Utamaro while simultaneously showing how Japanese women participating in ganguro appropriate African American culture through clothing and hairstyles.

\section{Translating Rozeal's Work with Hip Hop Pedagogy in Mind}

Through class discussions, at conferences, and in casual conversations, the main way that we hear of art educators utilizing Hip Hop Pedagogy is by engaging children in rapping about various traditional topics in art education-the color wheel or the elements and principles of art. While there may be good reasons to use rap in the classroom, we think that there may be other ways to implement aspects of Hip Hop Pedagogy as well. A good starting point is teaching about a range of contemporary artists who acknowledge the role of Hip Hop in their practice. For instance, with regard to Rozeal's work, she acknowledges the importance of Hip Hop in her life and we can see the role of street fashion as well in her images. She describes herself as a DJ in addition to being a visual artist (Williams and Brown 2006).

One way an art educator might teach about her is to explore issues of appropriation versus appreciation and the multiplicity of identity. Appropriation, in cultural terms, is taking something from another culture, usually a minority culture, and having someone from the dominant culture use it without showing a deep understanding of the item and why or how it was and is used by others. In contrast, appreciation involves respectfully borrowing or using cultural elements and acknowledging one's positionality as well as the inherent complexities in using elements from a culture other than one's own. Appreciation could also mean not sourcing the imagery from another culture, but examining the underlying meaning behind a practice, and connecting that to practices and values in one's own culture. For instance, instead of having all students draw skeletons and skulls for the Day of the Dead, a teacher might engage students in an understanding and appreciation of their ancestors and the students would have some choice in how they would represent their ancestors.

Appropriating cultural elements without acknowledging their origin is harmful, racist, and continues systematic forms of oppression. A recent example of this includes White Hip Hop 
musicians wearing cornrows while not acknowledging systemic racism and the fact that the musical style and hairstyle originated with African Americans. Related to this, the musical idea of sampling, taking a segment of a pre-existing song and using it within the context of a new song, is an element of Hip Hop relevant to Rozeal's work and postmodernism (Broome 2015). Additionally, she takes styles and remixes elements of older and newer cultural traditions. This hybridity and fluidity of her work combines such elements as a Burberry plaid with a person wearing cornrows in the style of Ukiyo-e prints. This becomes especially important when working with issues of cross cultural exchange, and the need to understand historical context.

Thus, we suggest that art teachers directly address appropriation and make the connection to sampling within Hip Hop music. Through a discussion of Rozeal's work and her commentary on the appropriation of Black culture, teachers and students could engage in meaningful discussions of what is a respectful use of another culture and how people choose to respond when they see a disrespectful use of their culture, as Rozeal does. One idea would be for students to research their cultural background and find media representations of it or students may use a site like Pinterest to locate lesson plans that purport to teach about their culture. Then, the students and teacher would need to take some time to study the representations that they find, deciding how they depict the culture. After this process, students would make some type of derivative work that comments on how they see their own culture represented in media images, if it leans more toward appropriation or appreciation. These pieces could be displayed alongside the original source images with a description of how the student analyzed the original work and how it relates to the students' cultural backgrounds. This engages students in the practices of being a counterstoryteller while acknowledging Hip Hop culture, students' own cultural practices, and engaging students in exploring how others have appropriated or appreciated their culture.

In addition to Rozeal's work, a teacher might also introduce other Black women artists including Mickalene Thomas and Faith Ringgold who both sample from Western male works of art. This sampling is incredibly purposeful as they comment on the lack of representation of women, and specifically Black women within the history of art. Thus, their use of imagery from older paintings is a political act, much like the political commentary that was an essential part of early Hip Hop. Through replacing White male figures and a nude White female figure with clothed strong Black women with natural hair, Thomas inserts Black women into the history of art in a powerful fashion in her piece Le déjeuner sur l'herbe: Les Trois Femmes Noires. (https://www.smithsonianmag.com/ arts-culture/mickalene-thomas-ushering-new-wave-contemporary-art-180967496/). Not only do the Black women literally take the place of White men, they are also looking directly at the viewers of the piece which is a sharp contrast to how women, and particularly women of color, are typically depicted in 19th century paintings (Tiffany 2018).

In Ringgold's The Sunflowers Quilting Bee, she samples a van Gogh sunflower image and includes portraits of important African American women as a sign of female solidarity in contrast to the traditional idea of the White male genius artist (Smith 1992). Further, in this piece Ringgold positions these women, from different eras, engaging in a collective form of quilting (http:/ / www. faithringgold.com/ringgold/d15.htm). Because the focal point of the piece is the women and their quilting, van Gogh, who is relegated to the side, almost becomes part of the background. The work of Thomas and Ringgold relates to Rozeal's work, but shows more connection to historical works of art and questions the absence of women, particularly Black women, within art.

Engaging students with studying the works of Rozeal, Thomas, and Ringgold or other artists (See Appendix A) requires that art teacher do more than ask students to swap out a figure and replace it with another. Delving into the history of Hip Hop, the political commentary of music, and the historic exclusion of Black women from visual arts would be necessary to help students build an understanding of these artists' work. Further, an art teacher would need to guide student through considering what type of statement they wanted to make through creating a work with sampled imagery and help students understand the differences between appropriation and appreciation. Teachers could facilitate 
discussions about what type of visual sampling would effectively communicate students' messages. In process critiques of student work would likely help students consider multiple perspectives on their own work and the ways representation, or the lack of it, affect contemporary perspectives.

\section{Conclusions}

Like all cultural art forms, Hip Hop is complex, evolving, and part of lived reality for millions of people. Due to its meaning within young people's lives, art teachers should make space for Hip Hop Pedagogy within their teaching practice. This requires that teachers adopt an asset-based approach to all their students, learn about a wide variety of cultures, and question what knowledge looks like and where and how it circulates. Further, teachers need to de-center themselves and their knowledge, recognizing that the Hip Hop artists their students know about and like may be vastly different from their own knowledge.

As we work to change practices within art education, we need to question some of our traditional practices and projects that are based on cultural appropriation. Instead, we need to find alternatives in how we work and in the projects we have students create. Educators need to consider ways of working that relate to appreciation, not appropriation. Further, it is crucial for educators to address the fact that the dominant (White) cultures in the United States have benefitted from appropriation in myriad ways, often commodifying and commercializing other cultures. At the same time, the cultures being appropriated (largely Black and Brown) do not receive benefits and are penalized for some of the same actions. To help our field move in this direction, we need to consider our students' cultures, how Hip Hop may be a part of their cultures and work to sustain what they bring with them to the classroom. We might work with our students to understand the core values of the artistic practices that they value and use those as guiding principles within the classroom. Further, we may need to question the existing values in visual art, largely based on early 20th century elements and principles of art (Gude 2007), and rethink these in light of contemporary practices and values (Emdin 2016). Though beyond the scope of this paper, art education could be informed by close study of Black feminism and how it informs Hip Hop pedagogy. Developing curriculum related to Black feminism could be a step toward changing the historical erasure of Black women from the field of art education (Acuff 2018).

Not all individual teachers have the power or ability to make radical changes on their own. To make systemic changes within education, we believe that teacher preparation programs need to radically shift to encompass a wider range of pedagogical approaches, including CSP and Hip Hop pedagogy. When pre-service teachers learn about contemporary pedagogy and ways to use Hip Hop artists and musicians that challenge "controlling images" and expand on nuanced, complex narratives (Hay et al. 2018, p. 5) to better relate to the lives of youth. Because the teaching workforce is overwhelmingly White, it is important that teachers recognize how systemic oppression and racism operate in schools and work to dismantle that. Working to validate and sustain Hip Hop and the cultures of our students is one way that White allies can assist in the dismantling of the current inequitable system.

Author Contributions: Both authors contributed equally to writing and editing this paper.

Funding: This research received no funding.

Acknowledgments: We would like to thank Gloria Wilson for reading a draft of this manuscript and offering us helpful feedback. We are grateful for her time and insights.

Conflicts of Interest: The authors declare no conflict of interest.

\section{Appendix A}

Other contemporary visual artists whose work we believe would be appropriate to address through the ideas of Hip Hop Pedagogy include:

Meriem Bennani

Melissa Falconer 
Faith Ringgold

El Seed

Amy Sherald

Roger Shimomura

Saba Taj

Mickalene Thomas

Izel Vargas

Kehinde Wiley

\section{References}

Abiko, Bonnie. 2003. Meiji period. Oxford Art Online. Available online: http://www.oxfordartonline.com/ (accessed on 21 August 2018).

Acuff, Joni Boyd. 2018. Black feminist theory in 21st century art education research. Studies in Art Education 59: 201-14. [CrossRef]

Alim, Samy H. 2011. Global ILL-literacies: Hip hop cultures, youth identities, and the politics of literacy. Review of Research in Education 35: 120-46. [CrossRef]

Anderson, Crystal S. 2007. The afro-asiatic floating world: Post-soul implications of the art of Iona Rozeal Brown. African American Review 41: 655-65. [CrossRef]

Bridges, Thurman. 2011. Toward a pedagogy of hip hop in urban teacher education. The Journal of Negro Education 80: $325-38$.

Broome, Jeffrey L. 2015. Using hip hop music to enhance critical discussions on postmodern art. Art Education 68: 34-39. [CrossRef]

Brown, Ruth Nicole. 2009. Black Girlhood Celebration: Toward a Hip-Hop Feminist Pedagogy. New York: Peter Lang.

Brown, Ruth Nicole, and Chamara Jewel Kwakye. 2012. Wish to Live: The Hip-Hop Feminism Pedagogy Reader. New York: Peter Lang.

Chung, Sheng Kuan. 2007. Media/visual literacy art education: Sexism in hip-hop music videos. Art Education 60: 33-38. [CrossRef]

Condry, Ian. 2007. Yellow b-boys, black culture, and hip-hop in Japan: Toward a transnational cultural politics of race. Positions: East Asia Cultures Critique 15: 637-71. [CrossRef]

Desai, Dipti. 2000. Imaging difference: The politics of representation in multicultural art education. Studies in Art Education 41: 114. [CrossRef]

Dubois, Jarvid. 2009. East/west meeting of the minds. International Review of African American Art 22: 44-45.

Durham, Aisha. 2007. Using [living hip hop] feminism: Redefining an answer (to) rap. In Home Girls Make Some Noise: Hip-Hop Feminism Anthology. Edited by Gwendolyn Pough, Elaine Richardson, Aisha Durham and Rachel Raimist. Mira Loma: Parker Publishing LLC, pp. 304-12.

Emdin, Christopher. 2016. For White Folks Who Teach in the Hood ... and the Rest of Y'all Too: Reality Pedagogy and Urban Education. Boston: Beacon Press.

Fernandes, Sujatha. 2003. Fear of a black nation: Local rappers, transnational crossings, and state power in contemporary Cuba. Anthropological Quarterly 76: 575-608. [CrossRef]

Gay, Geneva. 2000. Culturally Responsive Teaching: Theory, Research, and Practice. New York: Teacher's College Press.

Gude, Olivia. 2007. Principles of possibility: Considerations for a 21st century art education. Art Education 60: 6-17. [CrossRef]

Hay, Kellie, Rebekah Farrugia, and Deidre Smith. 2018. DS sense's “On my Detroit everything": Self-articulating black girl magic. Arts 7: 17. [CrossRef]

Hoch, Danny. 2006. Toward a hip-hop aesthetic: A manifesto for the hip-hop arts movement. In Total Chaos: The Art and Aesthetic of Hip-Hop. Edited by Jeff Chang. New York: Basic Civitas, pp. 349-63.

Jeffries, Michael P. 2014. Hip-hop urbanism old and new. International Journal of Urban and Regional Research 33: 706-15. [CrossRef]

Kuttner, Paul J. 2016. Hip-hop citizens: Arts-based, culturally sustaining civic engagement pedagogy. Harvard Educational Review 86: 527-55. [CrossRef] 
Ladson-Billings, Gloria. 1995. Toward a theory of culturally relevant pedagogy. American Educational Research Journal 32: 465. [CrossRef]

Levy, Ian, Christopher Emdin, and Edmund S. Adjapong. 2017. Hip-hop cypher in group work. Social Work with Groups 41: 103-10. [CrossRef]

Morgan, Marcyliena, and Dione Bennett. 2011. Hip-hop \& the global imprint of a black cultural form. Daedalus 140: 176-96.

Nochlin, Linda. 1971. Why have there been no great women artists? Art News. Available online: http:/ /www. artnews.com/2015/05/30/why-have-there-been-no-great-women-artists/ (accessed on 20 November 2018).

Paris, Django. 2009. "They're in my culture, they speak the same way": African American Language in multiethnic high schools. Harvard Educational Review 79: 428-47. [CrossRef]

Paris, Django. 2012. Culturally sustaining pedagogy: A needed change in stance, terminology, and practice. Educational Researcher 41: 93-97. [CrossRef]

Paris, Django, and H. Samy Alim. 2014. What are we seeking to sustain through culturally sustaining pedagogy? A loving critique forward. Harvard Educational Review 84: 85-100. [CrossRef]

Peoples, Whitney A. 2008. "Under construction": Identifying foundations of hip-hop feminism and exploring bridges between black second-wave and hip-hop feminisms. Meridians 8: 19-52. [CrossRef]

Petchauer, Emery. 2015. Starting with style: Toward a second wave of hip-hop education research and practice. Urban Education 50: 78-105. [CrossRef]

Powell, Linda S. 2012. 30 Americans: An inspiration for culturally responsive teaching. Art Education 65: 33-40. [CrossRef]

Rowell, Charles H. 2015. [Iona] Rozeal [brown]. Callaloo 38: 805-10. [CrossRef]

Smith, Roberta. 1992. Art in review. The New York Times, February 14. Available online: https:/ /www.nytimes. com/1992/02/14/arts/art-in-review-014792.html (accessed on 20 November 2018).

Smith, Marquita R. 2013. "Or a real, real bad lesbian": Nicki minaj and the acknowledgement of queer desire in hip-hop culture. Popular Music and Society 37: 360-70. [CrossRef]

De La Soul. 1989. 3 Feet High and Rising [Vinyl Record]. New York: Tommy Boy.

Tiffany, Y. Ates. 2018. How Mickaelene Thomas Is Ushering in a New Wave of Contemporary Art. Smithsonian Magazine. Available online: https://www.smithsonianmag.com/arts-culture/mickalene-thomas-usheringnew-wave-contemporary-art-180967496/ (accessed on 20 November 2018).

Williams, Lyneise, and Iona Rozeal Brown. 2006. Black on both sides: A conversation with Iona Rozeal Brown. Callaloo 29: 826-34. [CrossRef]

(C) 2018 by the authors. Licensee MDPI, Basel, Switzerland. This article is an open access article distributed under the terms and conditions of the Creative Commons Attribution (CC BY) license (http:/ / creativecommons.org/licenses/by/4.0/). 

Article

\title{
Homage or Biting Lines: Critically Discussing Authorship, Creativity, and Copyright in the 21st Century through Hip-Hop
}

\author{
Nicholas Leonard \\ Department of Art and Design Education, Northern Illinois University, DeKalb, IL 60115, USA; \\ ngleonard23@gmail.com
}

Received: 7 August 2018; Accepted: 19 November 2018; Published: 22 November 2018

\begin{abstract}
The inherent traits of digital media have challenged traditional understandings of artistic authorship and creativity. This division in understanding can clearly be observed in the popular culture context of hip-hop music. Hip-hop initially began with analog technologies such as vinyl record players, then transitioned to predominately digital mediums. This changeover in artistic mediums has been well documented by opposing viewpoints from hip-hop artists, consumers, record companies, and lawyers. By focusing on hip-hop for critical discussion on artistic authorship and creativity, art students can engage in discussion reflecting on their own artistic and online practices, and how these behaviors are legally supported or suppressed by copyright law.
\end{abstract}

Keywords: authorship; creativity; hip-hop; copyright; copyleft; technology

\section{Introduction}

The rapid development of digital technologies and their appropriation by both amateur and professional artists creates challenges to the modernist understandings of authorship and creativity. In addressing the philosophical debate between modern and postmodern art with students, Broome (2015) described his efforts using hip-hop as a tool to critically discuss the complex topics of appropriation, recontextualization, and layering in postmodern art. In this example, the general emphasis is on having students explore postmodern art and artists, discussing hip-hop examples alongside Sherrie Levine, Robert Colescott, the Guerrilla Girls, and others. Following the suggestions from this work to address larger societal issues, the discussion can be continued and refined to address common student digital media habits in relation to copyright laws and how authorship and creativity are impacted in this relationship. The purpose of this article is to support art educators in developing critical discussions regarding authorship, creativity, and copyright laws in the 21st century, using hip-hop as a connection to student interests.

All digital media is created with a binary code consisting of $1 \mathrm{~s}$ and $0 \mathrm{~s}$. The nature of binary code allows for the quick duplication of an original file and instant sharing of content over the Internet, allowing others to both possess and alter the digital work. These traits inherent to digital media allow for both the legal and illegal creation of content by the lay-person and the amateur artist. This issue can be easily identified when looking at current copyright laws and common Internet practices. Re-purposing images and videos to create memes, professional content being juxtaposed in an amateur Youtuber's video, or fan art expanding on popular culture narratives, are all examples of common Internet practices. These digital artworks have qualities unique to the digital binary medium in which they are formed, posing questions of originality and aesthetic value. These digital artworks have qualities unique to the digital binary medium in which they are formed, posing questions of originality and aesthetic value. While aesthetic issues have been by Mercedes (1998) in proposing 
an aesthetic paradigm shift for digital media, there is still much unrest regarding authorship and the creative processes of creating digital artworks.

When content is remixed it could be viewed as paying homage or it could be viewed as stealing other's creative content, which is referred to as biting lines. The obvious and subtle use of remixing in hip-hop provides ideal content for critically exploring the influences of digital media and the creative process from both artistic and legal perspectives. If civil-society and the law are to support creative endeavors using digital media, then informed discussions relating to the values of authorship and the creative process must take place in the art classroom to produce knowledgeable participants to develop resolutions.

\section{Authorship and Creativity}

In order to discuss the concepts of authorship and creativity, it is important to start by addressing foundational understandings that can shape bias to allow for a detailed critical review of current perspectives in a productive manor. Such foundational understandings can be compated to the common use of the term, normal science. Normal science refers to a paradigm that is so prevalent that it does not require explanation, it is just referenced as fact (Kuhn 2012). By operating within a normal science framework, there is an agreed upon view of how to interpret and address issues. This can be highly beneficial for various domains of knowledge to develop within society. When addressing creativity and authorship, one of the most influential paradigms comes from Plato's Phaedrus (Yunis 2011). In Phaedrus, Theuth (the God of writing) presents the concept of writing to King Thamus for his review of the new technology. Theuth explains that documenting words through the process of writing allows for accessible records that can be disseminated to large audiences and can be stored to stand the test of time. Thamus notes that the technology of writing does not increase an individual's knowledge, it instead allows for forgetfulness since the knowledge is accessible as a remote form of memory. Thamus is also highly critical of writing as the technology separates the words from the author, thus denying others immediate discussion with the creator. That in turn creates an environment for many people to claim false knowledge and/or use the content for unintended purposes. Through this interaction with the first form of recording technology, writing, we see the emergence of value on the author and the original. Authors are given utmost value as the creator of the words and they must be traced back from the writing in order to clarify knowledge. This action simultaneously validates the author as the original and the writing as a copy of the original, making the copy less valuable. This Platonic view of authorship from 274-279 BC has arguably been considered normal science for over 2290 years, still influencing present day perspectives of creativity and authorship.

In visual culture, the lived experiences of the individual are prioritized and the term art is expanded to include fine art as well as other items that individuals interact with, connect to, and use to form meaning and identity (Freedman 2003). Here the marble podium of fine art is removed to value lived experiences and the setting of artwork (Dewey 2005). Through the expansion of what is identified as art in a postmodern, visual culture paradigm, new everyday mediums such as, but not limited to, video games, commercials, product packaging, clothing, augmented reality, and virtual reality, all claim the label of art and should accordingly be addressed in the art classroom. Since value is placed on the individual's experiences and interests, visual culture art educators become tasked with creating an evolving student-centered curriculum. Currently, one prevalent global trend is hip-hop music and aesthetics. By addressing hip-hop's use of sampling and remixing in the art classroom, art educators can introduce critical theory to discuss how society values authorship, creativity, and copyright alongside the introduction of new digital media through a common and approachable conversation topic. 


\section{Hip-hop}

Hip-hop provides engaging student content that opens avenues to discuss larger potential paradigm shifting concepts (Broome 2015) of creativity and authorship through the use of sampling and digital media. In one definition of sampling, Hosken (2014) describes it as “...drawn from hip-hop and other pop genres, in which a recognizable portion of an existing recording, such as several measures of music or a characteristic vocal sound, is used in the creation of a new song (p. 73)". In this understanding, a small portion of another creation is used to help produce a new artistic work. This use of remix by hip-hop artists has long been recognized as a creative art form and has been documented by DJ Spooky, That Subliminal Kid (Miller 2010). Sometimes, the use of sampling in hip-hop can be easily identified in tracks that draw from highly popular and recognizable sources, such as the rhythmic hook of Rick James's "Superfreak" in MC Hammer's "U Can't Touch This", or the bass line of Queen and David Bowie's "Under Pressure" used in Vanilla Ice's "Ice Ice Baby". Other uses of sampling can be more subtle, drawing from less known sources, such as The Notorious B.I.G.'s use in "Juicy" of "Juicy Fruit (Fruity Instrumental Mix)" by Mtume in the opening and main melody, along with the even more subtle use of Rappin' Duke's laugh from the track "Rappin' Duke" played in the background at 0:41. Referencing current prominent names of hip-hop artists, such as Drake, Kanye West, A $\$ A P$ Rocky, and Kendrick Lamar, can provide great examples of sampling in songs to engage students in critical discussion. One large aspect of hip-hop culture that has not been addressed yet is the disc jockey (DJ), who plays exclusively prerecorded music on vinyl record turntables or digital variations of the vinyl record turntable.

The DJ has a special focus in the sampling and remix culture of hip-hop. In the early stages of the DJ, an individual would simply play records on the record player by selecting a song or an album to play one after another. In this sense, the turntable was simply a tool for playing the prerecorded music and the DJ was just a player of records. As the hip-hop movement grew, so did the role of the DJ. DJs such as Kool Herc, Afrika Bambaataa, Grandmaster Flash and his protégé Grand Wizard Theodore, began to alter the relationship between the DJ and the technology of the turntable. DJs created techniques such as the "breakbeat", where a song will loop right before the hook plays, and "scratching" where the record is spun in reverse creating a new sound profile. The developments of the breakbeat and scratching were significant because the job of a DJ now required skill to produce quality novel music through the editing of prerecorded music. This also turned what was once considered a finished product, the recorded song, into raw material to use for creative purposes, to scratch and remix.

Remix, as the name suggests, is re-mixing content. While the specifics of remix can change depending on the historical or cultural references, generally, remix consists of reconstructing content to present it in a new way. Remixing is separate from a mash-up, where an artist layers two or more songs to produce new content. One example of a mash-up is the landmark album, The Grey Album by DJ Danger Mouse (Brian Burton), as a mash-up of two albums: The White Album by The Beatles, and The Black Album by Jay-Z. In creating The Grey Album, DJ Danger Mouse layered the digital audio files of The White Album and The Black Album to combine the songs so that the melody of one source supports the vocals from another. Here the original sources are clearly recognizable despite being layered together to create a new musical piece. Another DJ, Girl Talk (Gregg Gillis), used mash-up techniques to include over 300 different sample sources in just 14 tracks in the album Feed the Animals released in 2008. While each DJ took various interpretations of mashing up digital content through a wide or limited range of sources, both were centers of wide fame and recognition for their ability to blend together the samples so seamlessly, allowing the listener to recognize the original content in a new context. On the other hand, remixing takes a sample and re-presents it within a new work such as Cardi B featuring Bad Bunny and J. Balvin's "I Like It" that notably remixes a sample of Pete Rodriguez's "I Like It Like That (A Mi Me Gusta Asi)". It is this clear use of sampling, mash-up, and remix used in hip-hop that allows for investigation of the artistic creation process. 
By investigating hip-hop songs for their use of sampling of content, students become critical researchers of art and the process of creation. Focusing on a critical discussion of authorship and creativity, art students address pop culture icons and themes and locate them within a greater historical context from a personal relationship and identity to the content. Resources such as the website WhoSampled.com provides students with the ability to explore hip-hop artists and songs though multiple search filters, including top artists or songs by popularity, artists who have sampled the most songs, and songs that have been used the most for sampling. Some students may be surprised to discover that the globally trending hip-hop song "Nice for What" by Drake released in 2018 contains at least three samples, including one that is 32 years old from the track "Drag Rap" by The Showboys released in 1986. Using resources such as WhoSampled.com, students can begin to dissect how current artworks connect to previous works within the visual culture theme of hip-hop. Specifically, through the use of sampling and remixing, both hip-hop artists and DJs are directly re-using others' material while simultaneously creating something new.

The cultural value of remixing and sampling can be addressed through the continued critical discussion of authorship and creativity in hip-hop music. The original content being sampled has an aura (Benjamin 1986) that connects the work to certain historical traditions and rituals. When the sampled content is remixed into a new context, philosophical debates can be presented as to how the disconnect from the original content's aura allows for new forms of interpretation, engagement, and expression. One way art educators can emphasize how the thoughtful use of remixing content can support deeper cultural value and meaning with students is through a critical review of the tool Deep Beat (deepbeat.org). Deep Beat is an artificial intelligence (AI) program developed by Malmi et al. (2016) developed with the goal of producing creative and meaningful rap lyrics. While the Deep Beat AI is highly successful in combining lyrics from multiple rap sources (sampling), does the use of sampling in this situation produce a more meaningful interpretation for the listener? How would Deep Beat's use of sampling compare to Jay-Z's use of "It's the Hard-Knock Life" from the Broadway musical Annie in his song "Hard Knock Life (Ghetto Anthem)"? Through this lens, the simple act of sampling can be teased out to refine the use of remix that richly promotes cultural meaning and the use of remix that appears more shallow in cultural value.

Such discussions on sampling and remix can then be directed toward the student's own artistic works to move theory into practice. Students' can critique their own works with a particular focus on visual sampling and remix. How does the sampled content present itself in the work and how can/does that use of content influence the viewer? Multiple postmodern art examples and artists have been outlined by Broome (2015) to assist students in exploring artistic remix through appropriation, recontextualization, and layering. Moving beyond such classroom discussions, students can be further directed to reflect on their own practices with digital media and the Internet. Memes, consisting of a digital image from popular culture with text superimposed, typically rely heavily on the sampled visual content and aura to bring about a deeper meaning to the overall meme. Having students construct their own meme can be one easy way to explore sampling and remix in practice with digital media. Furthering this bridge between theory and practice, students have been encouraged to deconstruct digital visual culture media (such as commercials) to their basic texts, liberating them from their previous aura and linear message (Ciampaglia 2012). Critiques of these student-made artworks can further challenge the students' philosophical understandings of authorship and creativity by adding a conversational dimension, asking if their artwork (or others) were made legally.

\section{Copyright and Copyleft}

Hip-hop's use of sampling brings into question the fundamental values of authorship and creativity from two general legal perspectives that have been described as the copyright and the copyleft. As the contradicting names suggest, the two are in confrontation of each other bringing radically different perspectives onto the same values of authorship and creativity. The copyright can be summarized as a group who view creative producers as individuals who put in hard work to 
develop original content. This perspective can align with Benjamin (1986) idea of "aura", creating the prerequisite for the concept of authenticity. In terms of copyright, Benjamin argues that an original work has presence in time and space. To the copyright, those who remix and sample are lazy recyclers of content and steal intellectual property. On the flip-side, the copyleft can be seen as a group that view those who sample and remix as talented creative individuals that utilize and combine available content to produce new material. An initial leader in the copyleft movement includes the video artist Phil Morton creating his Copy-It-Right, anti-copyright approach to freely sharing media art (Cates 2008). Interestingly, Walter Benjamin's concept of "aura" can also be used to support the copyleft in that the duplication of art allows for the content to be removed from its historical and ritual past to produce new combinations and meanings for the viewer. While the copyright and the copyleft appear to stand in stark contrast to each other, they both make their cases for valuing the creator of content and recognizing him or her for their skill to produce new works. Both groups present their understanding and values to courts to lobby for legal support. What varies between the copyright and copyleft is how each group goes about justifying their positions. By using hip-hop sampling and remixing as a starting discussion point, students can begin to reflect on how they perceive and value legal authorship and creativity in our current era of digital technology saturation.

Hip-hop artists' use of sampling and remixing has created many hit songs but not all of the attention received has been positive. Back in the 1980s and 1990s, when the use of sampling and remixing in music was quickly growing along with digital media, copyright law was in the forefront of arguments related to the legal and illegal use of content. Hip-hop artists were frequently involved in lawsuits involving samples that spanned a wide range, from small looping bass lines to entire sections of a verse or chorus (Runtagh 2016). Early lawsuits like Vanilla Ice's "Ice Ice Baby" sampling of Queen and David Bowie's "Under Pressure" bass line went to court in 1990. Just a year later, De La Soul's "Transmitting Life from Mars" was taken to court for sampling The Turtle's "You Showed $\mathrm{Me}^{\prime \prime}$. Both cases were settled financially out of court for undisclosed millions of dollars and songwriting credits. Other cases such as 2 Live Crew's "Pretty Woman" parody of Roy Orbison's "Oh, Pretty Woman", eventually went to the Supreme Court, which ruled in favor of 2 Live Crew in 1994. Similar issues related to copyright laws are still being debated today. Lawsuits regarding copyrighted music being sampled in the past four years have included the likes of Robin Thicke, Mark Ronson (track composer for Bruno Mars), and Lana Del Rey. Hip-hop culture is much larger than the music alone. Along with the music artists produce are the music videos.

One of the most financially successful video games, Fortnite, a major current popular culture trend, draws heavily from hip-hop culture through the unauthorized use of dance moves originating from music videos (Geaghan-Breiner and Fernandez 2018). Fortnite itself is a battle royale-styled shooter video game that is free to play but allows for optional in-game purchases that are all cosmetic, altering the players appearance and animations, but providing no clear advantage to game play. Some of the most popular dance moves purchased in Fortnite are from hip-hop artists' music videos, such as Snoop Dogg's "Drop It Like It's Hot", 2 Milly's Milly Rock dance performed in "Milly Rock" and Drake's "Look Alive". The Milly Rock dance was first performed and made popular by 2 Milly in 2014 and was appropriated by other hip-hop artists such as Playboi Carti and Kendrick Lamar, paying homage to 2 Milly. When Fortnite introduced the dance move to the game it was called "Swipe It", eliminating any recognition of 2 Milly. Other instances can be seen as more insulting, such as the "Shoot" dance performed by Memphis rapper BlockBoy JB in the video for his song "Shoot". Chicago artist, Chance the Rapper, has called out the injustice of Fortnite for not properly accrediting the hip-hop artists responsible for the dance moves, or providing any royalties for these optional in-game purchases. Here, copyright law does not address individual dance moves and instead focuses on chorographical work; these moves are not under copyright protection. These situations involving copyright law and hip-hop culture seem to show a consistent conflict of interest and equity regarding authorship and creative production. 
The copyright and copyleft camps both agree that the author has value but for different reasons, and the introduction of digital technologies and USA copyright law bring new stresses to these views. In identifying an author, those in support of copyright generally find value in who created the original product, while the copyleft typically finds value in the process, ingenuity, and effort of creating. In the USA, copyright policies were started in 1790 to support and protect creative individuals by allowing them to profit from their creations and to encourage the encouragement of learning. Once profit is made, the copyright ends and the content is shared as an educational benefit to the public allowing for cheaper reproductions (ex: brand name and generic drugs). When this law was initially created, the culture could be described largely as a Read Only (RO) culture (Lessig 2008). In a RO culture, the media is made by a select few professionals and the consumer can only consume the media. If the average American had a vinyl record or a book and wanted to duplicate it, the tools and financial requirements to do so would make it largely impractical. Since the individual, within reason, did not have the ability to copy media, copyright laws were directed largely at other companies who had the ability to make copies. As new digital media were created, the ability to make copies radically changed for the common individual. Digital media, composed of binary 1's and 0's in various formats (audio, images, videos, 3D printed objects, interactive virtual environments, etc.) could be easily copied and shared indefinitely online. This allowed for growth in what is known as a Read Write (RW) culture (Lessig 2008).

A RW culture has individuals who both consume and produce content as part of the digital visual culture. Social media websites are a great example of RW culture, as individuals are consuming content online and then producing content in reaction through the technologies allotted to them (ex: Snapchat via video, Instagram via photos and videos, and Facebook through text, images, and video). As digital technologies expanded so did the understanding of U.S. copyright law to address individual copying of legally protected material. Since copyright law has not traditionally addressed the individual, the idea of free cultural content has become a largely emerging viewpoint aligning with the copyleft. Now a dichotomy has formed between the two camps, the copyright and the copyleft, RO and RW cultures. If a discussion between the two perspectives is to occur, there must be a deeper understanding of core values in the creation process between author and product.

To help society create a resolution between the two combatant views of the copyright and copyleft, art educators can be an essential tool in critically addressing how creativity can be understood and valued. Since the art students of today will become future advocates and voters on these very issues, the experiences in the art classroom hold great potential for influencing this legal conundrum. Art educators have already begun to address the stresses and complexities that copyright law has imposed on the creative process, encouraging students to critically engage with digital media texts (Ciampaglia 2012). How art educators discuss creativity, both directly and indirectly, influences student perceptions. While the views of many hip-hop artists have been compiled by Miller (2010), consensus of how art educators discuss and explore creativity with their students still represents a wide spectrum.

During the dominant time period of discipline-based art education (Greer), creativity was understood as inherent in the individual with strong values of the true original artwork and single author. Correlating with the creation of the Internet and a more prevalent RW culture is the social psychology understanding of creativity presented by Csikszentmihalyi (1997). In this social creativity framework, creativity is a social accolade that is assigned by the experts in a field rather than a divine gift bestowed upon an individual. The new and novel product that is presented to the experts for review in this social psychology understanding does not generate in the individual alone, but is actually a combination from various domains of knowledge that were seen as previously unrelated. Here, a person has skills and abilities within one domain of knowledge that align to the current understanding of their field, and they take a new approach on the same issue through the perspective of another domain of knowledge. Thus, in social psychology's approach to understanding creativity, creativity is the knowledge and ability to know what to select and copy from two or more domains to produce a hybrid (remix) that is expected to have novelty and value within their respective field. 
Reducing this perspective to sweeping statements, creativity is the skillful selection and copying of material to produce new knowledge as valued socially by the experts in the field. Discussing these positions in reference to hip-hop alongside the students' own artistic practices will create more informed participants on the values of authorship, creativity, and the copyright politics that address them.

\section{Artists as Legal Activist}

Dominant discussion of the value of authorship, creativity, and copyright laws are presented in a winner-take-all scenario, with limited middle ground, so that every event is used to argue on the extremes of the debate spectrum. One example of this would be the quote by the philosopher Adorno (1941):

The beginning of the chorus is replaceable by the beginning of innumerable other choruses. The interrelationship among the elements or the relationship of the elements to the whole would be unaffected. In Beethoven, position is important only in a living relation between a concrete totality and its concrete parts. In popular music, position is absolute. Every detail is substitutable; it serves its function only as a $\operatorname{cog}$ in a machine.

While Adorno's statement comes from a time before digital media, his view regarding the modularity of popular music addresses the same values as current discussions revolving around digitally remixing and sampling music. The copyright adopts Adorno's argument to support that creative music should not use similar or copied measures. The copyleft uses the same Adorno argument as a clear recognition that many songs have similar patterns that are modular in nature, thus easier to select and use for remixing purposes. Other examples could be the previously discussed Grey Album by Danger Mouse or Feed the Animals by Girl Talk. In these examples, the copyright argues that this is a shining example of exploiting others' work and copyright infringement since only mash-up techniques were used. Meanwhile, the copyleft would use these albums as exemplars for the amazing products that could be produced through remixing alongside Deleuze (1994) arguments that everything in existence is just transformed. Since arguments likes these place common ground between a rock and a hard place, teaching students how to critically address the values of authorship and creativity can begin to open up a middle ground for civil discussion regarding creative practices and the politics associated to them.

Hip-hop provides an accessible popular culture reference for addressing the concepts of authorship and creativity in artworks across analog and digital mediums. Popular hip-hop artists through the decades have remixed and sampled from Grandmaster Flash, to The Notorious B.I.G., to Drake. By encouraging students to investigate hip-hop songs and artists from multiple decades using tools such as WhoSampled.com, creative lineages can be identified using sampling and other remix practices. This process can then be duplicated using other mediums, such as Childish Gambino's "This Is America" music video. Here, students can explore multiple instances of visual sampling and remixing, including racial images such as the Minstrel show face. In turn, hip-hop becomes both a primary source for discussion as well as a vehicle to critically discuss the visual arts more generally in regard to authorship and creativity across analog and digital mediums in the art classroom. Furthermore, hip-hop also addresses the conflict between artistic creation and copyright law.

In the United States of America, copyright law applies equally to large corporations and private individuals, resulting in legal issues to professional companies as well as amateur or hobbyist artists. The threatening of legal action and the removal of online content on media outlets like Youtube, and fan pages of popular culture movies and comics, are just a few examples of legal understandings for authorship and creativity targeting amateur artists. Depending on how individuals have grappled with the concepts of authorship and creativity, this may sound reasonable (copyright) or atrocious (copyleft). Since current laws may create villains and pirates out of individual amateur artists simply 
developing in a natural creative process, new or revised laws must be made to support creativity on both ends of the spectrum, professional and amateur.

Multiple scholars and authors have made suggestions for either replacing or updating current copyright law to reflect the new digital media era where remixes of music, images, and videos are common practice (Lessig 2008; Berry 2008; McLeod and DiCola 2011; Gunkel 2016). Lessig (2004) has proposed a "free culture" that allows for reasonable property rights that support the creators of the past without inhibiting the innovators of tomorrow. One of the seemingly most enacted options to address the overreach of copyright law is that of the Creative Commons, with currently over 1.1 billion licenses applied to creations. By using the Creative Commons website, creativecommons.org, you answer two simple multiple-choice questions regarding how you want your creation to be shared and if you will allow your creation for commercial uses. After selecting your two responses, a creative commons license is produced that you can apply to your artwork. There is even a visual icon that comes in two forms that you can insert into digital works or onto webpages. While the Creative Commons only addresses issues of creators legally identifying their new works to be shared, other issues pertaining to the use of copyrighted works and current copyright law are still unsettled. In order to address the remaining problems facing both civil-society and the law, students must engage in critical thinking regarding authorship and the creative process regarding digital media to be knowledgeable participants in creating the solution.

\section{Conclusions}

Digital media has challenged the traditional and modernist understanding of authorship and creativity. This fracture in understanding can clearly be observed in the context of hip-hop, where a transition from analog to digital mediums has paralleled the artistic habits of sampling and remixing of content, further resulting in legal issues due to copyright law. By presenting hip-hop as a common ground for the discussion of authorship, creativity, and copyright law, critical thinking at a meta level can be supported through relatable popular culture content. In this discussion, critical questions can be asked such as: How are creative ideas formed? What makes an author an author? What are the aesthetic qualities of traditional and digital art? How does the law support or impede creative development for both professional and amateur artists? It is through the critical discussion of these questions in the art room that will help produce insightful contributors to the present civil and legal issues regarding creative digital artworks. If civil-society and the law are to support creative endeavors using digital media, then informed discussions relating to the values of authorship and the creative process must take place in the art classroom to produce knowledgeable participants to develop resolutions.

Funding: This research received no external funding.

Conflicts of Interest: The author declares no conflict of interest.

\section{References}

Adorno, Theodor W. 1941. On popular music. Zeitschrift für Sozialforschung 9: 17-48. [CrossRef]

Benjamin, Walter. 1986. Illuminations. New York: Random House Digital, Inc., vol. 241.

Berry, David M. 2008. Copy, Rip, Burn: The Politics of Copyleft and Open Source. London: Pluto Press.

Broome, Jeffrey L. 2015. Using Hip-Hop Music to Enhance Critical Discussions on Postmodern Art. Art Education 68: 34-39. [CrossRef]

Cates, Jon. 2008. Copying-It-Right. Archiving the Media Art of Phil Morton. In Documentation and Conservation of the Media Arts' Media in Motion Symposium. Montreal: McGill University, vol. 29.

Ciampaglia, Steven. 2012. (De) Fencing the Cultural Commons Through a (De) Constructive Media Art Curriculum. Journal of Social Theory in Art Education 32: 80-95.

Csikszentmihalyi, Mihaly. 1997. Flow and the Psychology of Discovery and Invention. New York: Harper Perennial.

Deleuze, Gilles. 1994. Difference and Repetition. New York: Columbia University Press.

Dewey, John. 2005. Art as Experience. New York: Penguin. 
Freedman, Kerry. 2003. Teaching Visual Culture: Curriculum, Aesthetics, and the Social Life of Art. New York: Teachers College Press.

Geaghan-Breiner, Meredith, and Nick Fernandez. 2018. Rapper 2 Milly Says It's Clear Fortnite 'Stole' His Milly Rock Dance Move to Make Money-And He's Considering Legal Action". September 25. Available online: https:/ / www.businessinsider.com/can-you-copyright-a-dance-move-2018-9?r=UK\&IR=T (accessed on 7 August 2018).

Greer, W. Dwaine. Discipline-based art education: Approaching art as a subject of study. Studies in Art Education 25: 212-18. [CrossRef]

Gunkel, David J. 2016. Of Remixology: Ethics and Aesthetics after Remix. Cambridge: MIT Press.

Hosken, Dan. 2014. An Introduction to Music Technology. London: Routledge.

Kuhn, Thomas S. 2012. The Structure of Scientific Revolutions. Chicago: University of Chicago Press.

Lessig, Lawrence. 2004. Free Culture: How Big Media Uses Technology and the Law to Lock down Culture and Control Creativity. New York: The Penguin Press.

Lessig, Lawrence. 2008. Remix: Making Art and Commerce Thrive in the Hybrid Economy. New York: Penguin.

Malmi, Eric, Pyry Takala, Hannu Toivonen, Tapani Raiko, and Aristides Gionis. 2016. Dopelearning: A computational approach to rap lyrics generation. Paper presented at the 22nd ACM SIGKDD International Conference on Knowledge Discovery and Data Mining, San Francisco, CA, USA, August 13-17; pp. 195-204.

McLeod, Kembrew, and Peter DiCola. 2011. Creative license: The Law and Culture of Digital Sampling. Durham: Duke University Press.

Mercedes, J. Dawn. 1998. The application of feminist aesthetic theory to computer-mediated art. Studies in Art Education 40: 66-79. [CrossRef]

Miller, Paul. 2010. Sound Unbound: Sampling Digital Music and Culture. Cambridge: MIT Press.

Runtagh, Jordan. 2016. Songs on Trial: 12 Landmark Music Copyright Cases. June 25. Available online: https:/ / www.rollingstone.com/politics/politics-lists/songs-on-trial-12-landmark-music-copyrightcases-166396/lana-del-rey-vs-radiohead-2018-127024/ (accessed on 7 August 2018).

Yunis, Harvey. 2011. Plato, Phaedrus. Cambridge: Cambridge University Press.

(C) 2018 by the author. Licensee MDPI, Basel, Switzerland. This article is an open access article distributed under the terms and conditions of the Creative Commons Attribution (CC BY) license (http:/ / creativecommons.org/licenses/by/4.0/). 



\title{
The Intertextuality and Translations of Fine Art and Class in Hip-Hop Culture
}

\author{
Adam de Paor-Evans \\ Faculty of Culture and the Creative Industries, University of Central Lancashire, Lancashire PR1 2HE, UK; \\ arhevans@uclan.ac.uk
}

Received: 24 October 2018; Accepted: 12 November 2018; Published: 16 November 2018

\begin{abstract}
Hip-hop culture is structured around key representational elements, each of which is underpinned by the holistic element of knowledge. Hip-hop emerged as a cultural counter position to the socio-politics of the urban condition in 1970s New York City, fuelled by destitution, contextual displacement, and the cultural values of non-white diaspora. Graffiti-as the primary form of hip-hop expression-began as a political act before morphing into an artform which visually supported the music and dance elements of hip-hop. The emerging synergies graffiti shared with the practices of DJing, rap, and B-boying (breakdancing) forged a new form of art which challenged the cultural capital of music and visual and sonic arts. This article explores moments of intertextuality between visual and sonic metaphors in hip-hop culture and the canon of fine art. The tropes of Michelangelo, Warhol, Monet, and O'Keefe are interrogated through the lyrics of Melle Mel, LL Cool J, Rakim, Felt, Action Bronson, Homeboy Sandman and Aesop Rock to reveal hip-hop's multifarious intertextuality. In conclusion, the article contests the fallacy of hip-hop as mainstream and lowbrow culture and affirms that the use of fine art tropes in hip-hop narratives builds a critical relationship between the previously disparate cultural values of hip-hop and fine art, and challenges conventions of the class system.
\end{abstract}

Keywords: hip-hop; Bourdieu; cultural capital; class systems; hip-hop studies; graffiti art; hip-hop politics

\section{Introduction}

It is widely accepted in the hip-hop world that the culture is constructed of four main representational elements-DJing, B-boying, emceeing, and graffiti writing, underpinned with the fifth element of knowledge. ${ }^{1}$ Since the embryonic years of hip-hop culture during the 1970s, the already established graffiti movement operated as a complimentary visual practice to hip-hop's music and dance elements. As a political act first and an artform second, the association of graffiti within hip-hop developed into a recognizable touchstone for those outside the culture as a visual representation of the sound of the inner city. This idea remains most apparent through the sleeve designs of early 1980s vinyl releases such as Malcolm McLaren's Duck Rock, Jellybean's Wotupski!?!, and Schoolly D's self-titled debut, as well as the efforts of European compilation albums such as Jive's Breakdance Fever and Rap Attack, and Charly Records' Rap Graffiti. The visuals that adorn these sleeves embody varying levels of authenticity, and the messages they convey attempt to reaffirm hip-hop's connection to a strong sense of visual communication. The relationship between the music of hip-hop and visual arts

1 It should be noted that although the four practice elements mentioned above are the common construct of hip-hop culture, additional elements of beatboxing, production, and choreography are among further conceived elements. In the introduction to Jeff Chang's Can't Stop, Won't Stop (2007), Kool Herc points out there are far more elements than these, and includes more intangible suggestions of language, behavior, and communication. 
is far-reaching and loaded with intertextualities that challenge the social structure of class and the distinction of taste both within and outside the realm of hip-hop culture. One such intertextuality can be explored within hip-hop lyrics. Since the early 1980s, certain emcees have recoded fragments of the histories of high and fine art in their lyrics by using metaphor and narrative. In doing so, these emcees contest the position of high and fine art which in turn strengthen the cultural location of hip-hop and the broader discussion of taste and class.

Despite the international reach and impact that hip-hop culture has achieved over the past 40 years, there remain misjudgments about hip-hop's hierarchical status and position as an artform. While notable artists during the 1970s such as Fab 5 Freddy and Jean-Michel Basquiat explored the intersectionality of emerging hip-hop culture and established art culture, hip-hop became perceived by the mainstream media as a rebellious subculture loaded with negative connotations, hence missing the point of 'art as a political act' which was executed so intelligently by exemplary emcees such as Chuck D and KRS-One. By the turn of the millennium, hip-hop culture globally was operating across multiple liminalities and platitudes and attracting critical interrogations by commentators such as Paul Gilroy which "made it attractive to the art world" (Murray 2004, p. 5), thus generating a form of cultural capital. ${ }^{2}$ Murray states that the currency of hip-hop in terms of art criticism increases due to the "rising tensions between art history and visual studies" (ibid.), which explicitly becomes a question of taste and class. Gans claims that: "Taste cultures are not cohesive value systems" (Gans 2008, p. 94), but I would argue hip-hop's blatant consumer capitalism has eclipsed the deeper values of the culture itself which strongly relate to taste, and therefore it leaves no surprise that hip-hop can be effortlessly disparaged as a trite section of popular culture. However, the sheer girth of hip-hop is not solely built on capitalist consumerism and hip-hop's alternative, subaltern narratives that recode notions of art and restructure the production of cultural capital are the focus of this work.

My intention for this article is threefold. Firstly, I will demonstrate that the methodologies of metaphor-driven narrative in hip-hop lyricism produces a new cultural capital of hip-hop with which to critique high and fine art and progress hip-hop's creativity; secondly, I will attest that these lyricist practices challenge, reveal, and produce intertextualities within the class system and the distinctions of taste; thirdly, I will present a new reading of cultural capital where the creative outputs of hip-hop culture significantly inform those of high and fine art. On this third intention, presenting hip-hop as a politically charged artform — which subverts the accepted cultural capital of high and fine art-is key to this article. At various points in the ensuing discussion I attest the productions of graffiti and rap artists as politically motivated: as subversions of high and fine art and the art of hip-hop itself. This threefold inquiry is led initially by a brief cultural positioning of the visual within hip-hop, which in turn frames an analysis of the recoding of high and fine art motifs and tropes in hip-hop lyrics. This analysis draws upon the lyrics of 'golden era' greats LL Cool J, Rakim and Melle Mel, and more contemporary underground artists Homeboy Sandman, Aesop Rock, Action Bronson, and Felt (Murs and Slug) between the turn of the millennium and 2012. This examination is underpinned by Bourdieu's theories of distinction, class and taste (2010) and modes of cultural production (1993) which subsequently leads to a new way of considering embodied, objectified, and institutionalized cultural capital. The article concludes by attesting the use of fine art tropes metaphorically and narratively in emcees' lyrics calls into question the cultural status of hip-hop in the broader creative industry and society, cements a critical relationship between hip-hop and fine art, and signals new directions for the practices of fine art and hip-hop culture.

2 Although figures such as Gilroy brought cultural weight to the currency of hip-hop, both the economic capital and cultural framing of rap was already two decades deep due to the critical operations and actions within the culture itself. 


\section{Another Picasso, Another Michelangelo}

Graffiti is the obvious practice that comes to mind when one considers the visual representations of hip-hop. Since its inception at the tail end of the 1960s and first presented in mainstream media during 1971 (TAKI spawns pen pals. The New York Times. July 21), graffiti grew from the destitution of Robert Moses' ill-conceived urban planning, cultural displacement, and the strength of non-white diasporas (Mailer et al. 2009; Castleman 1982; Evans 2014) and was at first a political act. When I met graffiti photographer Jon Naar in Trenton, New York during August 2012, he expressed his views on the agenda of graffiti stating that for the past 40 years he had firmly believed it is a political act first, and only an artform second. Poring over Jon's extensive collection of graffiti photographs, we discussed the point at which graffiti became more palpable as art during 1972 when the development of its letters began to fatten out, duo and tri-color schemes were experimented with, and the first hints of characters, landscapes and a sense of depth arrived. Despite this morphing period which resulted in a more recognizable artform, the political act was still very much present through its visual impact; no longer was graffiti purely about tagging. However, it is important to reiterate that even during the primary bombing years up to 1972-1973, the artform of the letter and the number cannot be denied, but this was of secondary importance to the notion of 'getting up'. ${ }^{3}$ I was enthralled by this and wholeheartedly agreed for two reasons. Firstly, I had recently begun to work on the first chapter I wrote on the subject where I presented graffiti as a spatio-political counterpoint to the failed architecture and displacement experienced in New York City's ghettos (Evans 2014), and; secondly, I began to understand that within graffiti, the synergy between the making of art and the political act of free art and territorial ownership was paramount to its success, a combined quality that, for me, made graffiti more powerful than any contemporaneous examples of fine art.

There is much academic work that suggests how the graffiti pandemic took its historical course and how popular imagery was appropriated by graffiti writers, but little to pinpoint notions of fine art within graffiti culture. In the documentary Style Wars, writer DEZ speaks of his protégé TRAP:

He's like a son to me in a way, you know, I look out for him he looks out for me, you know I won't let nothing happen to him, he won't let nothing happen to me, if he can help it, you know. I know from his age, he's 14 now, you know, I'm 16, by the time he gets [to] my age he'll be one of the best people out, if he continues to go on in the years he could be another Picasso. (Style Wars 1983)

This is a revealing moment; not only does the tutor-mentor role and a kind of loco parentis become evident (Evans 2014), but DEZ's reference to Picasso within his suggested trajectorial aim for TRAP illustrates an understanding of Picasso as an exemplary art figure. Furthermore, DEZ strongly alludes to a double-edged broader cultural phenomenon here. By stating that " ... in the years he could be another Picasso", DEZ predicts both the longevity and worldwide success of graffiti culture and the notion that training as a graffiti writer-artist could prepare one for accomplishment as a professional artist. Additionally, selecting Picasso as a name may imply a closeness between Picasso's work and graffiti. Picasso's Regjeringskvartalet murals in Oslo and his 1939 muralesque Guernica share affinity with the top-to-bottom whole cars painted throughout the late 1970s and 1980s by graffiti writers, not only in terms of scale and abstraction, but also in political value. CASE 2, also interviewed in Style Wars, "was upstate" (Style Wars 1983) until late 1972, and noticed the impact of graffiti upon his return to his neighborhood. As he tells the story of his induction into graffiti, he recalls: "So when I got home I seen writing on the train, I said 'what's this stuff here?' you know, 'niggas doin' they names big,' I said 'let me do one of these' you know, 'cause I was down with art already. So, I did me a piece" (ibid.). CASE 2 clearly links his previous experience with art to graffiti, and by doing so the self-proclaimed 'King-of-Style' became a legendary figure in graffiti and

3 To 'get up', or 'getting up', is common phraseology in graffiti world meaning to execute graffiti in the public realm. 
hip-hop culture. These dialogues suggest the first inklings of an intertextuality within hip-hop culture where textual references are descriptive, discursive and reinforced by visual translations through spray-can to train. The depth of intertextuality in graffiti is evident through its inclusion of a range of cultural figures which to those outside the culture are placed in varying hierarchies of taste. As much as Picasso and other paradigm-shifting fine artists are referenced, so too is the lowbrow culture of comic books, advertising slogans, and tropes of television: graffiti writers deconstruct and reassemble what Smoodin explains (in the context of comic books) as "a representational system that allows the individual to encounter and interpret his or her social surroundings" (Smoodin 1992, p. 132). Graffiti's embracing and synergizing of high and low culture and its subsequent placing on a level playing field is salient to point out; as a forerunner to the metaphor-driven intertextual signals in rap music, graffiti assumed an ownership and reframing of high and low culture, in some ways postmodern yet pragmatic in its approach.

Michelangelo is another key figure cited by hip-hop practitioners, although here a kind of intertextual relationship is forged between the great discussion of fine art and lyrics from hip-hop's golden age. Three celebrated emcees, Melle Mel, LL Cool J, and Rakim (arguable contenders for the title of greatest emcee of all time) all use Michelangelo metaphorically. Melle Mel references Michelangelo in the 1984 film Beat Street (1984), in the New Year's Eve party scene which is also the wake for RAMO, the graffiti protagonist in the movie, who meets his end while pursuing SPIT (RAMO's nemesis, a writer who persists to write over RAMO's work) in a subway tunnel. RAMO's best friend and DJ Kenny 'Double K' Kirkland curates the wake which sees him and the Furious Five perform the sharp synth-driven "Beat Street Breakdown", although the entire lyrics are written and recorded by Melle Mel. The song is exemplary of Melle Mel's epic lyrical skill (74 bars in verse one, and 46 bars in the second) which contains diverse subject matter from the death of close friends and urban dilapidation to religious genocide, but the line important to this discussion is: "... 'Cause each and every time you touch a spray-paint can/Michelangelo's soul controls your hands" (Grandmaster Melle Mel and the Furious Five 1984). Here, Melle Mel speaks to the late RAMO, directly connecting emotional attachment between his untimely passing and the soul of Michelangelo, thus positioning RAMO also as a great artist. RAMO's death also adds to the perceived value of his work, analogous with increased posthumous capital such as in the work of Vincent Van Gogh and Paul Gauguin, which Melle Mel's lament further expresses:

And where murals stand on walls so grand

As far as the eyes are able to see, ha

I never knew art till I saw your face

And there'll never be one to take your place (ibid.)

Returning to the previous line, Melle Mel's proposition that Michelangelo's soul controls RAMO's hand as he paints, draws connotations with the idea of the masterpiece. In graffiti culture, a masterpiece (commonly abbreviated to 'piece') is a flawlessly executed full work which spans and occupies its site wholly, much in the same way Michelangelo's work at Sistine Chapel fully occupies the length and breadth of the building's ceiling. As the author of this world-famous early 16th century work, which since has been described as one of the greatest artistic accomplishments of the civilized world (Coughlan 1966; Gardner 1970), Michelangelo is celebrated as one of the greatest artists in history. However, Melle Mel's choosing of Michelangelo as the actor for his portrayal of RAMO's graffiti skills connotates with more than the notion of the masterpiece, art fame and the fame sought by graffiti writers. Here, Melle Mel presents graffiti as a powerful counter-point to established high art. By appropriating Michelangelo in the context of "Beat Street Breakdown", Melle Mel empowers graffiti to outshine the realm of Renaissance classicism. The idea of high art is owned by hip-hop: it becomes educationally potent as its galleries are not white-walled, guarded hierarchical interiors 
with privileged access, but are free-running throughout the city, subverting the class systems of high art production and appreciation. ${ }^{4}$

LL Cool J (1987) incorporates Michelangelo into a more traditional hip-hop freestyle braggadocio. On the opening four bars to "My Rhyme Ain't Done", LL raps:

The President woke and he called the Pope

The Pope climbed to heaven on a golden rope

P.S. the Lord raised Michelangelo from the dead

So he can make a fresh painting of my head (LL Cool J 1987)

Delivered over raw drum machine patterns, LL places himself as the subject of a piece of work by Michelangelo. As LL pulls other globally significant figures such as the President, the Pope, and the Lord into the narrative he creates a scenario where he locates himself at the apex of a regal-hierarchical structure whereby actors-usually associated with superiority and leadership--are carrying out a series of tasks to produce a mint painting of LL Cool J's head. Ultimately, the listener can imagine a portrait of LL hanging somewhere in the White House, akin to Michelangelo's Tondo Doni, (his only surviving easel painting) as it hangs in le Galleria degli Uffizi, Florence. Evidently, Michelangelo made fewer traditional paintings than three-dimensional work which may explain LL's use of the word 'head' rather than face. Additionally, this may hypothetically result in a rarer Michelangelo painting as he seldom painted sole portraits, plus his relief and sculpture work carried strong narratives which LL also weaves into his lyrics.

Rakim uses the Michelangelo reference in a first-person metaphor in "No Omega" (Eric B and Rakim 1990). Rakim introduces himself: "I'm the alpha with no omega ... " positioning himself as the cyclical continuum of rap. Four lines after this opening lyric he delivers:

Rhyme everlastin' there'll be no part two

Knowledge is infinite once I start to draw

A better picture for your third eye if you're blind

You know with a mic I'm the Black Michelangelo (ibid.)

Three interrelated points are important here. Firstly, Rakim raps about fine art and hip-hop aligned to knowledge. Secondly, he compares the art of rap with The Renaissance, and thirdly he appropriates the name Michelangelo to position himself as a dialectic Black figure with equivalent standing in hip-hop culture to the perceived high arts of The Renaissance. Here, I will expand on the first point. Since the inception of the Universal Zulu Nation (UZN) in the 1970s, knowledge has been key to hip-hop's progression, and it is crucial to understand the significance and nuances of knowledge in hip-hop culture. Knowledge underpins and intersects the four representational elements of graffiti, DJing, B-boying, and rap. One can only become an expert in an element if one acquires the knowledge which underpins that element. As the practices of hip-hop are so highly representational, they become at risk of being interpreted as purely skill-based, yet, it is the knowledge about the element in question which is required to learn and progress in one's chosen element—in turn improving one's skills and representations; fine tuning one's art. Knowledge sources in hip-hop are

4 This notion of the subverted gallery is further argued in the song "Schlangen Sind Giftig" by Stieber Twins (1999), where, as graffiti writers, they position themselves as "Picassos" in " .. Unser Louvre, kostenlos ... " (trans. " .. Our Louvre, free of charge ..."). Additionally, this illustrates how graffiti was considered primarily as a politically-charged artform following its transglobal journey. For further cultural framing of graffiti as art, see Subway Art (Cooper and Chalfant 1984); and Spraycan Art (Chalfant and Prigoff 1987). 
wide-ranging and multifarious and are located in the processes and productions of hip-hop practices such as lyrics, rhythm and scratch sonics, graffiti pieces and lettering styles as well as the more ephemeral dance moves, speech, and body language of B-boying. However, knowledge runs far deeper than simply learning about the elements' history and practical applications. Identified as hip-hop's fifth element by Afrika Bambaataa himself (Gosa 2015), knowledge was initially framed through the UZN's Infinity Lessons as well as Bambaataa's DJ sets where he would drop in sections of speeches by Black visionaries (Chang 2007, pp. 105-6). According to Gosa: “'Knowledge of self' refers to the Afro-diasporic mix of spiritual and political consciousness designed to empower members of oppressed groups" (Gosa 2015, p. 57), and this mix of consciousness relates to both knowledge of self and intertwined sociohistorical upliftment. Keyes argues that understanding the material culture of hip-hop and rap music is located in the urban environment, as: "The streets nurture, shape, and embody the hip-hop music aesthetic" (Keyes 2004, p. 122), and for devotees of hip-hop dwelling outside the realm of the city, critical examinations of hip-hop's artifacts, cultural history, and broader social contexts must be habitually executed to understand one's position in the culture.

\section{The Cultural Capital of Hip-Hop}

To frame this discussion within Bourdieu's notion of cultural capital, knowledge in hip-hop invariably contains the three facets of embodied (Bourdieu 1993, p. 270, n. 24; Bourdieu 2010, p. 70), objectified (Bourdieu 2010, pp. 69, 172), and institutional cultural capital (ibid., pp. 73-74). Taking these in order, the embodied is the cultural capital of one's background and upbringing, and how this manifests into thoughts and disposition of mind, in turn translated into actions. These accrue as one journeys through hip-hop culture, continually reflecting on one's position in relation to one's actions via engagement and the actions of others: for many lyricists and graffiti writers their experiences of hip-hop culture drove their art to be informed by a self-reflexive metadiegesis. The objectified is the capital of the material object, artifact, or thing; in hip-hop, objectified cultural capital is the output of engagement and action such as a vinyl record or a painted train. Here it can be clearly understood that the embodied relates directly to the objectified where tangible productions provide representations of both consumer and producer of the thing. The practices of hip-hop culture evolve through negotiation and navigation between embodied and objectified forms of cultural capital, but what of the institutional? A key component of institutional capital is that of education where, for example, attending certain academies determine a sense of identity for students, and following graduation they obtain titles or qualifications which deem them appropriate for a particular position of power and authority. As knowledge of self, non-white diasporas, and the social context of America deepened throughout hip-hop culture, a positive rejection of the conventional institution was generated, and a culture-driven form of institutional capital was developed by critically-informed artists. In effect, hip-hop culture, and especially the Universal Zulu Nation, became an ethereal institution.

During the late 1980s, artists like Public Enemy, Poor Righteous Teachers, and Jungle Brothers (1989) made concrete the esoteric notion of institutional hip-hop cultural capital through their narratives. In "Acknowledge Your Own History" (1989), Jungle Brothers anecdotally present their experience of the conventional school institution's lack of Black history education, and in particular the invisibility of Black culture in school text books. ${ }^{5}$ On the subject of heritage, Afrika Baby Bam raps about the wealth and cultural depth of his African forefathers, and follows by confronting the western denial of slavery: “ . . Y You ain't gonna find it in your history book/Come here, young blood, and take a look...", which he continues: "... You look at the pictures and all they show is/AfriKan people

5 Further examples include "I Can" by Nas (2002), and "Lyrical Maniac" by Blade (1989), who, whilst not Black, was born in the Armenian quarter of Iran and experienced the effect on his family of the Islamic revolution. In "Lyrical Maniac", he raps: “... Form of intelligence form of knowledge/When I left school I went straight to college/Schoolin' schoolin' teachers never taught me/Never went class but they never caught me/Even in lessons instead of learning/I wrote the lyrics I was aching burning ..." (Blade 1989). 
with bones in their noses ... " (Jungle Brothers 1989). Mike G continues this attack on formal American education: "Yeah, I cut class, I got a D/'Cause history meant nothing to me ... ", framing the context of class, he continues: “... I'd talk to girls or write a rhyme/'Cause I didn't know all times are Black man's times ..." (Jungle Brothers 1989). This is a protest song in essence-a song which eloquently and simultaneously attests the existence of rich African histories and attacks the editing of culture and through the narrative of the western objectified school text book. Through protests like this, the institutional cultural capital of hip-hop as a new culture formed and a concurrent awareness of African art came to fruition, particularly to those hip-hoppers with no previous knowledge of African heritage or culture. In hip-hop, the institutional is not the bricks and mortar of the established academy, but the establishing of the knowledge which underpins the culture. To this end, the vehicles of translation of this institutional capital are the actions, practices and artefacts of hip-hop culture. Whilst the actions and practices can be ephemeral, temporal and fluid-particularly in the case of freestyle rap and scratching, B-boying, and graffiti-when documented as artefact the knowledge value is either evident or signposted within the embodied capital. The recordings of Jungle Brothers and X-Clan (1990) particularly signpost African arts and their embodied cultural capital, emphasizing their histories hidden by the western world. As "Acknowledge Your Own History" draws to a close, the spoken-word outro asserts: "AfriKa, is the mother of civilization on the planet Earth. AfriKa, where science, cosmetics, knowledge, wisdom and understanding all comes from ... " (1989), and similarly in the spoken-word intro to X-Clan's "Verbs of Power" (1990), Professor X the Overseer states: "We of the Blackwatch now arrest the demonic mind state of mortals for the following crimes: religion, art, sciences, government, writing, mathematics, astrology, philosophy, inventions, culture, sense of reality, speech techniques ...". These are hugely significant statements which aver the value of embodied African cultural capital, and of particular relevance to this article is the weight with which westernized hijacking and siloed categorization of the holistic practices of arts and humanities are exposed and rejected. To this end, it is not any named artist from the canon of western fine art which takes a position in hip-hop, but the universal notion of creative culture itself.

Returning briefly to Rakim, his metaphor as a Black Michelangelo relates to embodied, objectified and institutional cultural capital. His phrasing that, "... Knowledge is infinite ..." and reference to, " ... your third eye ..." (the eye of Horus) demonstrates a conviction that his artform takes listeners to the higher state of consciousness associated with the concept of the third eye (Darnell 1997), and an infinity of knowledge is triggered once Rakim draws a metaphorical picture. In the lyrics following this, he states that: " ... with a mic I'm the Black Michelangelo", again amplifying the intertextuality inherent in the languages of visual art and hip-hop lyrics, and furthermore juxtaposes the western canonical figure of Michelangelo with African spirituality. The result of this comparation makes clear Rakim's understanding of cultural attitudes to artforms within the context of hip-hop culture, promoting a heritage-driven form of cultural capital.

\section{New School Capital}

The new wave of underground hip-hop artists in the new millennium brought both an expansion and reaffirmation of hip-hop's practices. Aesop Rock, Homeboy Sandman and Felt pushed the envelope of lyrical flow while Action Bronson asserted archetypal hip-hop styles with consistent professionalism, and all these artists continue to contribute to hip-hop's diversity. Action Bronson's sluggish vibe radiates through on the Alchemist-produced "Eggs on The Third Floor" (2012), a song of two acts where the first reeks of lackadaisical style before the second slams into skull-snapping boom bap. Spanning these two approaches, Bronson's lyrics twice refer directly to economic capital through the lines: "... Old money in the bag look like sautéed spinach bitch ... " and "... Gravitatin' towards the money 'cause it brings me joy ... " (Action Bronson 2012), and throughout the song Bronson delivers in excess of thirty metaphors and several similes. These allegories contain a common theme which is one of extreme subversion, no greater illustrated than in these four bars:

Neidhart, ride dirty in the five sharp 
Hand skills, Jean Claude, fine art

Put my head right through the Monet, ole

All the drugs I smoke, my lungs are probably coal grey (ibid.)

Bronson's proposal to rip open a Monet painting with his head may demonstrate-even via the narrative-a seditious disregard for high art, although this is not quite so. The position Action Bronson is in fact promoting is that of the conquering emcee, and in freestyle raps such as this, it is commonplace to destabilize cultural capital through the metaphor. What is of interest here is the way in which Bronson selects a situation, an action, and embodied capital of a Monet painting as the vehicle of communication. Furthermore, Bronson's choice to place Monet as the artist in his lyrics also carries echoes of posthumous capital. Critics and broader society struggled with Monet's works while he was alive considering them sketchy and unfinished (Yilmaz 2009), yet they gained increased cultural and economic value after his death once his influence became evident in the paintings of the post-impressionists (Tucker 2007). A painting cannot be remade by an artist once they are dead; Bronson's act intends to both shock and illustrate the boundaries he is prepared to push as an emcee.

Slug and Murs, both of whom debuted on vinyl in 1997, joined forces as Felt during the noughties and between 2002 and 2005 released three albums, all of which were titled as ironically masculine tributes to famous American female actors: A Tribute To Christina Ricci, A Tribute To Lisa Bonet, and A Tribute To Rosie Perez. The Felt project is partially a diversion from their respective more serious work, yet on "I Shot a Warhol" (Felt 2005) the closing song on A Tribute To Lisa Bonet, the lyrics slide into messages of drug fallout and tumbled lifestyles, threaded together by the chorus hook:

I shot a Warhol

Dead with my pistol

When the wind hit the hole

In the canvas it whistled

Beautiful with no frame

A face with no name

Glass full of cold fame

Chased it with slow pain (ibid.)

Whilst the metaphors for a life ruined by hard drugs vibrate strongly here, a more literal reading reveals more than simply a literal translation. These words empower the listener to visualize with great clarity the scenario after a bullet punctures a canvas. ${ }^{6}$ Here, the narrative is not about destabilizing cultural capital like Bronson—but much like Warhol—is about an ironic destabilizing of the broader societal image of mainstream branded cultural icons, a scenario painted through oscillations of metaphor (" ... the coke side blinds you ..." ) and non-metaphor ("Nostrils of cocaine ... "). Simultaneously the song calls into question the values of aesthetic approach and cultural content in Warhol's productions. Although Felt do not directly reference Warhol's Elvises, one is reminded immediately of his silkscreen series through Felt's lyrics. One can imagine Murs and Slug standing together in a double-shootout opposing multiple cowboy-dressed Elvises, as Felt challenge the very

6 There is also a mediated intertextuality at play here with Bob Marley's "I Shot The Sheriff" (1974), the hook of which was extensively sampled by EPMD on "Strictly Business" (1988) and offers a different translation, as well as Non Phixion's "I Shot Reagan" (Non Phixion 1998) and Warren G's pastiche intertextual cover version of "I Shot The Sheriff" (1997). 
essence of 'Elvisness'. By 'Elvisness', I mean the commodified, and replicated processes that led to a structured method of creating economic capital by appropriating the cultural capital of rock n' roll by media industries, resulting in superstardom for Elvis and beyond; a method that Warhol builds upon, reframes, and makes evident through his own formulaic Elvises.

In 1963, Warhol's silver Elvis paintings were exhibited at the Ferus Gallery, Los Angeles. The Elvis paintings had been shipped to the gallery "singly, doubly, and in multifigured groups" (McCarthy 2006, p. 356), with the intention to install a penetratingly intense show. The images themselves are inconsistently consistent-uneven in tone and detail—the 'Elvis' series resonate with Warhol's earliest films which hold small regard to technical film criteria. McCarthy also observes that: "Warhol's method of labored production perpetuated the life of a genre given over to repetition and cliché at its inception" (ibid., p. 364), which also draws comment on the tired cowboy film genre and its inherent representations. There is a further idea here resonating with Warhol's films, the intertextuality of 'the shot', and his play on time and speed, as most of his films were "shot at sound speed but shown at slow, silent speed" (Rees 2010, p. 83). By framing Elvis from the 1960 film Flaming Star rather than imagery of John Wayne or James Stewart (from the 1962 film Who Shot Liberty Valance, for example), Warhol subverts the ideological American masculine; Elvis' portrayal of a cowboy is less than conventional, and tinted with hints of femininity and campery. Feeney remarks that: " ... the movie period is the black hole of Elvis's career" (Feeney 2001, p. 54), and his performance in Flaming Star is no exception, yet it is this portrayal which plays perfectly into the social commentary Warhol seeks.

\subsection{Artist as Soup Tin: Branding as Translations of Fine Art and Hip-Hop}

So, how do the clichés of gender, American popular culture, masculism, faux confidence, and power that Warhol challenges through his parodic presentation of a fading Elvis relate to Felt's "I shot a Warhol"? To answer this, I will further dissect the chorus hook. "... When the wind hit the hole/In the canvas it whistled ..." (Felt 2005) describes the aftermath of puncturing a canvas with absolute precision through the act of the shot. The listener is led to believe the shot was central, materially flawless, and visually impeccable, and one can almost envisage its perfect penetration at slow speed. This is accentuated by the following words "... Beautiful with no frame ..." (ibid.), which literally deletes Warhol's suggested precision in his framed prints as much as their social recontextualizations and commentaries. If the frameless becomes beautiful, one may conject that the subject of Warhol's art is returned to its original state and value, or is somehow revalued. The chorus continues "... A face with no name/Glass full of cold fame ... " (ibid.), which picks up on Warhol's alleged comment: "In the future everyone will be famous for 15 minutes" (Warhol and Hackett 1983, p. 165). This lyric raises questions about Warhol's ironic prediction as much as his own fame, and begins to relate the pop art period with the contemporary issues of social networking and status. By considering Felt's lyrics in the context of present-day society, the attitudes to fame sought by so many through social media platforms resonates with the idea of artist-as-celebrity and the film and music celebrities Warhol chose to portray: Elvis, Elizabeth Taylor, Marilyn Monroe, John Lennon, and James Dean, as well as himself.

By producing work that positions these subjects alongside representations of everyday products such as Campbell's soup tins, the notion of celebrity-as-brand is revealed. This branding has now seeped into the lives of ordinary citizens, as they redesign themselves as a brand through ephemeral social media representations. Khamis et al. (2017, p.192) point out the problems associated with personalized branding: "Branding an individual raises conceptual, practical and ethical issues, which are either not acknowledged or are simply glossed over by its advocates". They continue to suggest one of the biggest issues with self-branding is the difficulty in sustaining a high-level of consistency. Are these branded personalities of ordinary citizens a form of fine art or cultural capital? They could be both. Khamis et al., state that: 
As 'ordinary' people seek and find fame through practices of micro-celebrity, they redistribute cultural power in both media and marketing: implicitly, micro-celebrity points to the growing agency, enterprise and business acumen of everyday media users. (ibid., p. 197)

I would further this argument to suggest that through the actions of fame-seeking and self-branding, ordinary citizens produce forms of cultural capital which personify ideas of high art and taste. These actions-in the form of social media posts-are constructed of a collection of representations of intention (Bourdieu 2010, p. 53), uploaded to demark one's distinct taste "vis-à-vis lower groups" (ibid.). This personification becomes a subconscious parody of Warhol's work, and, to relate this back to hip-hop, the everyday hip-hopper yearns for a "glass full of cold fame". The ordinary citizen and the hip-hop practitioner-whatever their artistic status-seeks their 15 minutes of fame, and through the social media condition of the post-global world-will have "chased it with slow pain" when its promise of sustained fame inevitably fails. In the wake of the sole global hip-hop superstar, a concept spawned by Tupac and amplified by Kanye West and Jay-Z, those underground hip-hop artists who choose to seek fame through social media platforms engage in the kinds of practices suggested by Khamis et al. However, the very actions of engaging with such practices reveal significant differences between using social media as a platform for self-promotion and using social media as a creative, cultural tool which also inform a creative narrative. As far back as 2002, UK-based artist Blak Twang (2002) cited his own website in the song "On Line", in the mid-noughties Dirty Diggers joked about their number of MySpace followers during live performances, and Task Force (2006) formed a dark narrative surrounding a vindictive engagement through MySpace on the diss song "The Bitches" (2006). Metaizations such as these exploit social media through creativity; the social media platform is consumed by the work of the artist and becomes a platform for artistic translation and metareference. These inventive uses of social media extend the life of the 15 minutes of fame and become artistic practices in their own right, and contemporaneously reframe the comfort afforded by social media as "populist objectivism" (Bourdieu 2010, p. 42). By removing the necessary devices required for the portrayal of a social media presence, the third space of the digital (Soja and Chouinard 1999) becomes devoid and is overtaken by the practices of the artist in making new sonic art.

\subsection{Intertextual Lyrics as Critiques of Hip-Hop and Fine Art}

Homeboy Sandman turns to Georgia O'Keefe on the grimy industrial sound of "Sputnik", where he expands his braggadocio to contain a six-fold metaphor aimed at weaker rappers. Concluding with the line "... All their art screams pussy like Georgia O'Keefe's/Stop it" (Homeboy Sandman 2012), Homeboy Sandman bluntly expresses the overtones of O'Keefe's work, which, as part of the modern world of women's sexual art "... were abstract and ambiguous subconscious manifestations, often denied by the artist herself" (Semmel and Kingsley 1980, p. 1). According to Chicago and Schapiro:

O' Keefe's oeuvre opens up the possibility of human expressiveness heretofore unavailable, particularly to men. Implicit in this is a suggestion that just as women have suffered when measured by male standards, so men might be found lacking when measured by the standards of that work by women which assert softness, vulnerability and self-exposure. (Chicago and Schapiro 2003, p. 41)

Homeboy Sandman slices through the perceived division of fine art and hip-hop with his single mention of O'Keefe amidst more predictable cultural references such as Lacoste, Jean Luc Pickard, and Nintendo's Donkey Kong. By suggesting the art produced by "hard rocks" does nothing more than "scream pussy", Homeboy Sandman draws traditional slang (often appropriated in hip-hop) into the metaphoric assessment of O'Keefe's paintings, and by so doing reflects and inverts Chicago and Schapiro's observations. Sandman's metaphor is double-edged as it critiques O'Keefe's work and the efforts of the hard rocks simultaneously, and whilst he uses the terminology 'pussy' to detriment the hard rocks' art, it is not intended with any disrespect to O'Keefe but rather highlights the 
deficiencies in men when considered alongside the assertions of women. Homeboy Sandman's counter phrase "stop it" - which brusquely yet nonchalantly closes the verse, challenges these metaphors and is delivered with an intonation that suggests partial contempt and partial offense-can be interpreted as a commentary on the prevalence of male chauvinism in hip-hop. This small, common two-word phrase is the fulcrum of meaning in this song. Ultimately, this critical lyric from "Sputnik" firmly attests Chicago and Schapiro's claim that O'Keefe's work reveals previously inaccessible possibilities of expressiveness in humankind, and simultaneously proposes that much male hip-hop rhetoric remains a fair way off. "Sputnik" does much to challenge the perceived embroilment of class system and misogyny which coexisted in hip-hop even before its commercialization, although capitalist exploitation of hip-hop's values has amplified these negatively in an attempt to contain the productions of hip-hop as popular, lowbrow culture.

\subsection{Reframing the Critique: Art as the Holistic}

Aesop Rock's "No Regrets" (2001) explores the notion of visual art holistically. Rather than the multi-layered metaphors of the artists discussed previously, Aesop Rock delivers a narrative following the life of protagonist Lucy from seven years of age to her death 80 years later. The listener learns that from this young age, she would make chalk drawings of everyday people, cityscapes, skyscapes and sunsets on the street, until after a year of drawing "... She covered every last inch of the entire sidewalk ..." (Rock 2001). In verse two, the listener discovers that Lucy is in her late 30s and although lives as a hermit, is in a relationship with another artist but they seldom meet. She continually declines invitations from people in her neighborhood for lunch dates which escalates local gossip about Lucy's behavior, although she is bothered little by this: “ ... 'Cause while they spread their rumours through the street/She'd paint another masterpiece ... " (ibid.). In the third and final verse, Lucy is "upon her death bed", and prior to this "... pinned up a life worth's of pictures on the wall ..." to which she "... blew a kiss to each one of her pictures and she died" (ibid.). The chorus hook, delivered after each verse, is framed moralistically:

$1-2-3$ that's the speed of the seed

A-B-C that's the speed of the need

You can dream a little dream or you can live a little dream

I'd rather live it 'cause dreamers always chase but never get it (ibid.)

The chronicles of Lucy become a parable of sorts, an allegory for how one chooses to live life. With other cultural cues such as eschewing double Dutch as a child and never switching on her television in the retirement home, the listener is left with the belief that Lucy rejected lowbrow and mainstream culture in favor of spending time making art. Aesop Rock makes a clear distinction between popular culture and the act of drawing, and through the practice of rap a judgement of taste arises but rather than fixated on a tangible object, artifact, or made piece of art, this judgement of taste is about lifestyle choice and art praxis. The cultural capital of Lucy-as-art is what then becomes the metaphor for the song. As Lucy grows her life experience revolves around the making of pictures; these pictures become her surroundings, touchstones and reference points. The value of Lucy's art therefore has contextually embedded value in its idea and making, her upbringing allowed her to experiment at length with chalk drawing in her childhood, developing into a richness of embodied cultural capital. At the dusk of her life, Lucy surrounds herself with the drawings she made throughout her existence-a collection of objectified cultural capital of some distinction-which offers her deep solace. This echoes with Aesop Rock's approach to cultural discourse and also resonates with many hip-hop practitioners, who, since the awakenings of the Universal Zulu Nation to The Native Tongues collective, Public Enemy, KRS-One, X-Clan, Poor Righteous Teachers, and a plethora of other conscious crews during the early 1990s have deepened cultural critique through their art. Since the enlightenment of the late 1980s, 
many culturally engaged hip-hop practitioners draw upon metaization as a way to consolidate both their professional praxis and personal position in their respective cultural context. "Meta-referential discourses almost always imply heterogeneous elements mixed unexpectedly" (Arhip 2012, p. 125), and in hip-hop emceeing this self-reflexivity-existing through the metaphors of lyrics-then brings the challenges of the content to the listener.

\section{Conclusions: Fine Art and the Future of Hip-Hop}

In this article, I have exhibited a snapshot of key fine art metaphors and references within lyricism and graffiti throughout the golden and new school ages of hip-hop culture. The discussion surrounding DEZ, TRAP, and CASE 2 attest to the presence of fine art in graffiti culture through verbal discourse as much as the painted word, revealing these graffiti pioneers considered the political act of graffiti as art. Furthermore, the auto-reflexivity embedded in the praxis of graffiti writers theoretically positions graffiti empathetically with other forms of fine art; the recurring self-referentiality of writers' names-repetitively painted over the surfaces of the built environment resonate with the fine artist's absent-present relationship with the gallery. In terms of lyrics, the metaphors and references to canonical members of the fine art establishment do more than merely link the artists of hip-hop with the artists of fine art. As I have demonstrated, the complex structure of rap techniques-as an artform in itself-is a credible vehicle for the production of a twofold counternarrative and cultural critique: challenging both the art of hip-hop and fine art. Hahl et al. argue that: "To be sure, many 'lowbrow' cultural products are expressly produced to impress an audience" (Hahl et al. 2017, p. 832), which is dialectical to the search for knowledge of self, sociohistorical upliftment and contestation of high and fine art by hip-hop artists. Critique of high and fine art as well as cultural capital and its framing vis-à-vis lowbrow and mainstream culture is particularly evident in the analysis of Felt and Homeboy Sandman, and the analysis of Aesop Rock's "Lucy" provides a further testament to the reflective, rigorous appraisals that are a core facet of underground hip-hop's evolution.

Furthermore, I have revealed that these critical practices confront the status of fine art's canon by reimagining through lyrical content, and by doing so challenge the assumed judgments of taste and class by and of hip-hop artists. These responses to class system are much more than a riposte and form a judgement of taste which both reframes the productions of underground hip-hop and the productions of fine art-instating hip hop's cultural capital. One must reflect on the Basquiat-produced "Beat Bop" (Tartown Record Co., 1983) by Rammellzee and K-Rob, complete with Basquiat's sleeve and label artwork, and remember that originally only 500 copies were printed of this masterpiece which fused underground lyrics, spaced-out experimental rhythms, and fine art. The value inherent in "Beat Bop" foreran the placing of hip-hop in any form of cultural value outside the culture itself. "Beat Bop" as an artefact underpins the visual concepts of Basquiat and Rammellzee and affords a refreshed reading of hip-hop as cultural capital. The absorption of fine art in hip-hop, growing richer since the creation of "Beat Bop", makes visible the intertextual values in the processes and productions of hip-hop's products which have previously remained shadowed by the celebrated economic capital gains of artists such as Jay- $Z$ and Kanye West. Although Jay- $Z$ and Beyoncé take ownership of obvious high art culture, not least represented in The Carters' "Apeshit" video (2018) which presents switching scenes of Jay- $Z$ and Beyoncé occupying the interior and exterior of I.M. Pei's postmodern Louvre Museum in Paris, this suggests temporal economic status rather than a takeover of high art's cultural capital.

Williams discusses thoroughly the sub-genre of jazz-rap and its functionality as a construction whereby: “ . . jazz-rap represented the creation of a unique type of high art within the rap music world ..." (Williams 2010, p. 436), but is keen to point out that here he means "high art" within hip-hop as a term distinctive from its use in the broader cultural domain (ibid.). It is clear that the interpretive codes of jazz, sampled and signposted in jazz-rap draw a sonic intertextuality with the sophistication of jazz, thus legitimizing it as a high art sub-genre of hip-hop. Whilst Williams is absolutely correct in his conclusion, this is disturbing and abandons the larger remaining part of 
hip-hop which seemingly exists vacuously. What I have shown in this article is that there survives a range of criticality in hip-hop which contests high and fine art. The future for hip-hop needs to be much more than hip-hop being accepted as art by the high and fine art world, it must be about the perceptions of high art and the practices of fine art being surmountable by hip-hop praxes. Moreover, the embodied capital of knowledge, politics, history, and creative practice that thrives in much of hip-hop culture can and should influence the embodied, objectified and institutional cultural capital of high and fine art. The future of underground hip-hop needs to take advantage of its rich absorption of high and fine art discussed throughout this article and become a placemaker for fine art, forging a conceptual yet tangible space for continuing cultural critique. Within this space-a realm other than those of established hip-hop or fine art- these two seemingly disparate cultures can learn from and inform one another. Furthering discursive exchange in this way will help to address the glaring (mis)representations of bigotry and materialism in hip-hop's cultural capital, and question the (mis)conventions of status in high and fine art.

Funding: This research received no external funding.

Conflicts of Interest: The author declares no conflict of interest.

\section{References}

Action Bronson. 2012. Eggs on The Third Floor. Rare Chandeliers, [CDr Unofficial].

Arhip, Odette. 2012. Characteristics of Meta-Referential Discourse in Arts. Philologica Jassyensia 8: 123-27.

Beat Street. 1984. Directed by Stan Lathan. Los Angeles: Orion Pictures.

Blade. 1989. Lyrical Maniac. London: Raw Bass Records, [Vinyl Record].

Bourdieu, Pierre. 1993. The Field of Cultural Production. Cambridge: Polity Press.

Bourdieu, Pierre. 2010. Distinction: A Social Critique of the Judgement of Taste. London: Routledge.

Castleman, Craig. 1982. Getting Up: Subway Graffiti in New York. Massachusetts: MIT Press.

Chalfant, Henry, and James Prigoff. 1987. Spraycan Art. London: Thames \& Hudson.

Chang, Jeff. 2007. Can't Stop, Won't Stop: A History of the Hip-Hop Generation. London: Ebury Press.

Chicago, Judy, and Miriam Schapiro. 2003. Female Imagery. In The Feminine and Visual Culture Reader. Edited by Amelia Jones. London: Routledge, pp. 40-43.

Cooper, Martha, and Henry Chalfant. 1984. Subway Art. New York: Holt, Rinehart and Winston.

Coughlan, Robert. 1966. The World of Michelangelo. Time-Life International. New York: Time, Inc., p. 116.

Darnell, John. 1997. The Apotropaic Goddess in the Eye. Studien Zur Altägyptischen Kultur 24: 35-48.

Eric B and Rakim. 1990. No Omega. In Let The Rhythm Hit 'Em. New York: MCA Records, [Vinyl Record].

Evans, Adam. 2014. On the Origins of Hip-Hop: Appropriation and Territorial Control of Urban Space. In Consuming Architecture: On the Occupation, Appropriation and Interpretation of Buildings. Edited by Daniel Maudlin and Marcel Vellinga. Oxon: Routledge, pp. 185-202.

Feeney, Mark. 2001. Elvis Movies. The American Scholar 70: 53-60.

Felt. 2005. I Shot A Warhol. In A Tribute to Lisa Bonet. Minneapolis: Rhymesayers Entertainment, [Vinyl Record]. Gans, Herbert J. 2008. Popular Culture and High Culture: An Analysis and Evaluation of Taste. New York: Basic Books. Gardner, Helen. 1970. Art through the Ages. Harcourt: Brace and World.

Gosa, Travis L. 2015. The Fifth Element: Knowledge. In The Cambridge Companion to Hip-Hop. Edited by Justin A. Williams. Cambridge: Cambridge University Press, pp. 56-70.

Grandmaster Melle Mel and the Furious Five. 1984. Beat Street Breakdown. In Beat Street (Original Motion Picture Soundtrack--Volume 1. New York: Atlantic, [Vinyl Record].

Hahl, Oliver, Ezra W. Zuckerman, and Minjae Kim. 2017. Why Elites Love Authentic Lowbrow Culture: Overcoming High-Status Denigration with Outsider Art. American Sociological Review 82: 828-56. [CrossRef] Homeboy Sandman. 2012. Sputnik. In First of a Living Breed. San Mateo: Stones Throw Records, [Vinyl Record]. Jungle Brothers. 1989. Acknowledge Your Own History. In Done by the Forces of Nature. New York: Warner Bros. Records, [Vinyl Record].

Keyes, Cheryl Lynette. 2004. Rap Music and Street Consciousness. Chicago: University of Illinois Press, vol. 441.

Khamis, Susie, Lawrence Ang, and Raymond Welling. 2017. Self-branding, 'micro-celebrity' and the rise of Social Media Influencers. Celebrity Studies 8: 191-208. [CrossRef] 
LL Cool J. 1987. My Rhyme Ain't Done. In Bigger and Deffer (BAD). New York: Def Jam Recordings, [Vinyl Record]. Mailer, Norman, Mervyn Kurlansky, and Jon Naar. 2009. The Faith of Graffiti. New York: It Books.

McCarthy, David. 2006. Andy Warhol's Silver Elvises: Meaning through Context at the Ferus Gallery in 1963. The Art Bulletin 88: 354-72. [CrossRef]

Murray, Derek C. 2004. Hip-Hop vs. High Art: Notes on Race as Spectacle. Art Journal 63: 5-19. [CrossRef]

Nas. 2002. I Can. In God's Son. New York: Columbia, [Vinyl Record].

Non Phixion. 1998. I Shot Reagan. New York: Uncle Howie Records, [Audio Cassette].

Rees, Alan Leonard. 2010. A History of Experimental Film and Video, 2nd ed. Basingstoke and Hampshire: Palgrave Macmillan.

Rock, Aesop. 2001. No Regrets. In Labor Days. [Vinyl Record]. New York: Def Jux.

Semmel, Joan, and April Kingsley. 1980. Sexual Imagery in Women's Art. Woman's Art Journal 1: 1-6. [CrossRef]

Smoodin, Eric. 1992. Cartoon and Comic Classicism: High-Art Histories of Lowbrow Culture. American Literary History 4: 129-40. [CrossRef]

Soja, Edward W., and Vera Chouinard. 1999. Thirdspace: Journeys to Los Angeles and Other Real and Imagined Places. Canadian Geographer 43: 209. [CrossRef]

Stieber Twins. 1999. Schlangen Sind Giftig. In Schlangen. Germany: MZEE Records, [Vinyl record].

Style Wars. 1983. Directed by Tony Silver. New York: Public Art Films.

Task Force. 2006. The Bitches. London: Not On Label, [Vinyl Record].

Tucker, Paul. 2007. Monet and the Challenges to Impressionism in the 1880s. In Critical Readings in Impressionism and Post-impressionism: An Anthology. Edited by Mary Tompkins Lewis. Los Angeles: University of California Press, pp. 227-51.

Twang, Blak. 2002. On Line. In Kik Off. London: Bad Magic, [Vinyl Record].

Warhol, Andy, and Pat Hackett. 1983. POPism: The Warhol Sixties. New York: Harper \& Row.

Williams, Justin A. 2010. The Construction of Jazz Rap as High Art in Hip-Hop Music. The Journal of Musicology 27: 435-59. [CrossRef]

X-Clan. 1990. Verbs of Power. In To the East, Blackwards. New York: 4th \& Broadway, [Vinyl record].

Yilmaz, Asim E. 2009. Influences of Electromagnetic Theory on Modern Art. IEEE Antennas and Propagation Magazine 51: 202-5, Removed for peer review. [CrossRef]

(C) 2018 by the author. Licensee MDPI, Basel, Switzerland. This article is an open access article distributed under the terms and conditions of the Creative Commons Attribution (CC BY) license (http:/ / creativecommons.org/licenses/by/4.0/). 


\title{
Hip Hop Family Tree Treasury Editions: A Book Review for Art and Visual Culture Educators
}

\author{
Jeffrey L. Broome \\ Department of Art Education; Florida State University, Tallahassee, FL 32306, USA; jbroome@fsu.edu
}

Received: 12 December 2018; Accepted: 24 December 2018; Published: 29 December 2018

\begin{abstract}
This book review examines Ed Piskor's Hip Hop Family Tree as compiled and packaged by Fantagraphics into two gift box sets featuring a total of four treasury editions of collected works. The basic premise of Hip Hop Family Tree focuses on a loose narrative detailing the historical development of hip-hop culture as depicted in a comic book format. The review begins with a brief summary of each treasury edition with a specific focus on selected vignettes detailing the role that visual art has played in hip-hop culture. The review closes with a discussion of the overall relevance of Piskor's work to those working in art and visual culture education.
\end{abstract}

Keywords: Hip Hop; visual culture; art education

\section{Introduction}

Visual art has always played an essential role in hip-hop culture, initially—and perhaps most visibly-in the form of fashion trends and graffiti during hip-hop's early developmental period throughout the mid-1970s and early 1980s (Fricke and Ahearn 2002). In the decades since then, the relationship between visual art and hip-hop culture has evolved. Comic book artist, Ed Piskor, contributed to that evolution when he began publishing Hip Hop Family Tree in short installments on the Boing Boing website in 2012 (Piskor 2012). In 2013 Fantagraphics began publishing collected versions of these online comics in print form, and has since released two gift box sets that feature four treasury editions of compilations that were respectively released in 2014 and 2016.

The basic premise of the Hip Hop Family Tree series focuses on a loose narrative tracing the historical development of hip-hop culture depicted in a graphic novel format. Both gift sets (Piskor 2014, 2016) come in a sturdy illustrated box, each containing two oversized softback treasury editions (approximately $9.25^{\prime \prime}$ by $13.25^{\prime \prime}$ ) produced in full color. Each of these treasury editions consists of over 90 pages of Piskor's comic narrative, along with varying supplementary materials in the form of pinup art, commentary, indices, or other reference materials. In the text below, I will offer a brief summary of each treasury edition while highlighting specific points of relevance to practitioners interested in connections between hip-hop and visual art. I will close this book review with a brief discussion of the overall relevance of Piskor's work to those working in art and visual culture education.

\section{Overview of Treasury Editions}

The first treasury edition focuses on the time period beginning in the mid-1970s and concluding in 1981, with a general emphasis on the widely accepted narrative that hip-hop's origins can be traced to community center parties located in the Bronx. It is at these parties that disc jockeys (DJs), such as Kool DJ Herc, began experimenting with multiple turntables to blend together existing drum breaks into extended patterns that were meant to energize those in attendance (Fricke and Ahearn 2002). Much of the story that follows focuses on the DJs, such as Grandmaster Flash and Afrika Bambaataa, who rose to prominence after Herc was sidelined in a dramatically-depicted altercation involving a 
knife-wielding audience member. Along the way, masters of ceremonies or microphone controllers (MCs) were integrated into these DJs' performances to add rhymes over looped drum tracks.

Other major characters in the first treasury edition include Russell "Rush" Simmons, Sylvia Robinson, and other burgeoning managers, producers, or record executives who competed to either cash-in on hip-hop as an assumed short-lived fad or in nurturing hip-hop toward sustained commercial success. While the popular breakthrough of studio-produced hip-hop recordings is credited to "Rapper's Delight" by the hastily-assembled Sugarhill Gang in 1979, it is actually Kurtis Blowe (managed by Simmons) who earns the first official gold record in hip-hop history with his song, "The Breaks". The first treasury edition of Hip Hop Family Tree climaxes in dramatic fashion with a legendary rap battle between Busy Bee Starski and Kool Moe Dee.

Readers who are interested in exploring intersections between hip-hop culture and visual art will find that the first treasury edition includes a notable thread detailing Fab 5 Freddy (Fred Brathwaite) and his development as both a graffiti artist and as a hip-hop pioneer. This thread depicts Braithwaite's involvement with Lee Quinones and his Fabulous Five crew in tagging Warhol-inspired Campbell's soup cans along the sides of subway trains. The recognition and media attention that comes along with this high-profile act leads to later art shows for Braithwaite in Rome and also in Manhattan art galleries, where he is in contact with other street-inspired artists such as Jean-Michel Basquiat and Keith Haring (Figure 1). Through these connections, Braithwaite is shown striking up friendships with Debbie Harry and Chris Stein from the popular new wave band, Blondie, who eventually use his moniker in the lyrics of their single, "Rapture", and also include Braithwaite, Quinones, and Basquiat in the accompanying music video.

The second treasury edition covers the years from 1981-1983 and continues to use a series of brief vignettes to intermittently describe the growing influence and visibility of hip-hop culture and graffiti artists in fine art galleries and venues in downtown Manhattan. In one of these vignettes, Piskor details events surrounding the Braithwaite-curated art show entitled, "Beyond Words: Graffiti Based, Rooted, Inspired Works", held at the Mudd Club. The focus of another vignette is on Malcolm McLaren's inclusion of hip-hop musicians, dancers, and graffiti artists as an opening showcase prior to a concert by the new wave band, Bow Wow Wow. Fab 5 Freddy and Futura 2000 were included as featured visual artists in the latter event, whereas the former event included works of art by Haring, Basquiat, Rammellzee, Dondi White, Kenny Scharf, Zephyr, and others.

The second treasury edition also documents the production of two films on the subject of hip-hop culture that featured graffiti and street-inspired artists in prominent roles. More specifically, Lee Quinones and Lady Pink played the lead roles in Charlie Ahearn's Wild Style (1983) alongside Zephyr and Fab 5 Freddy; New York Beat Movie-later re-titled Downtown 81 (2000)—featured Jean-Michel Basquiat as the main character, with Quinones and Fab 5 Freddy this time in supporting roles. While New York Beat Movie also included some of Basquiat's collaborative musical work on its soundtrack, Piskor rightfully turns his attention more toward Basquiat's musical ventures through his legendary involvement in the production of the hip-hop song, "Beat Bop", by K-Rob and fellow visual artist, Rammellzee (Nosnitsky 2013) (Figure 2).

Elsewhere, separate story threads in the second edition emerge that are more loosely related to art and design. For instance, some readers may be interested to find that Chuck D (Carlton Ridenhour) was a graphic design major at Adelphi University who used his skills to create logos for his earliest hip-hop groups before eventually leading Public Enemy to critical success. Similarly, Piskor reveals how hip-hop producer, Rick Rubin — then still an undergraduate at New York University—took such care in launching his independent record label (Def Jam Recordings) that he hand-designed the company's iconic logo with resources available from Estee Lauder's art department where his aunt was employed. More generally speaking, the second treasury edition of Hip Hop Family Tree also traces the growing success of hip-hop music through Afrika Bambaataa's "Planet Rock", the social consciousness of Grandmaster Flash and the Furious Five's' "The Message", the emergence of a west coast rap scene, and the earliest days of Run-DMC's career development. 

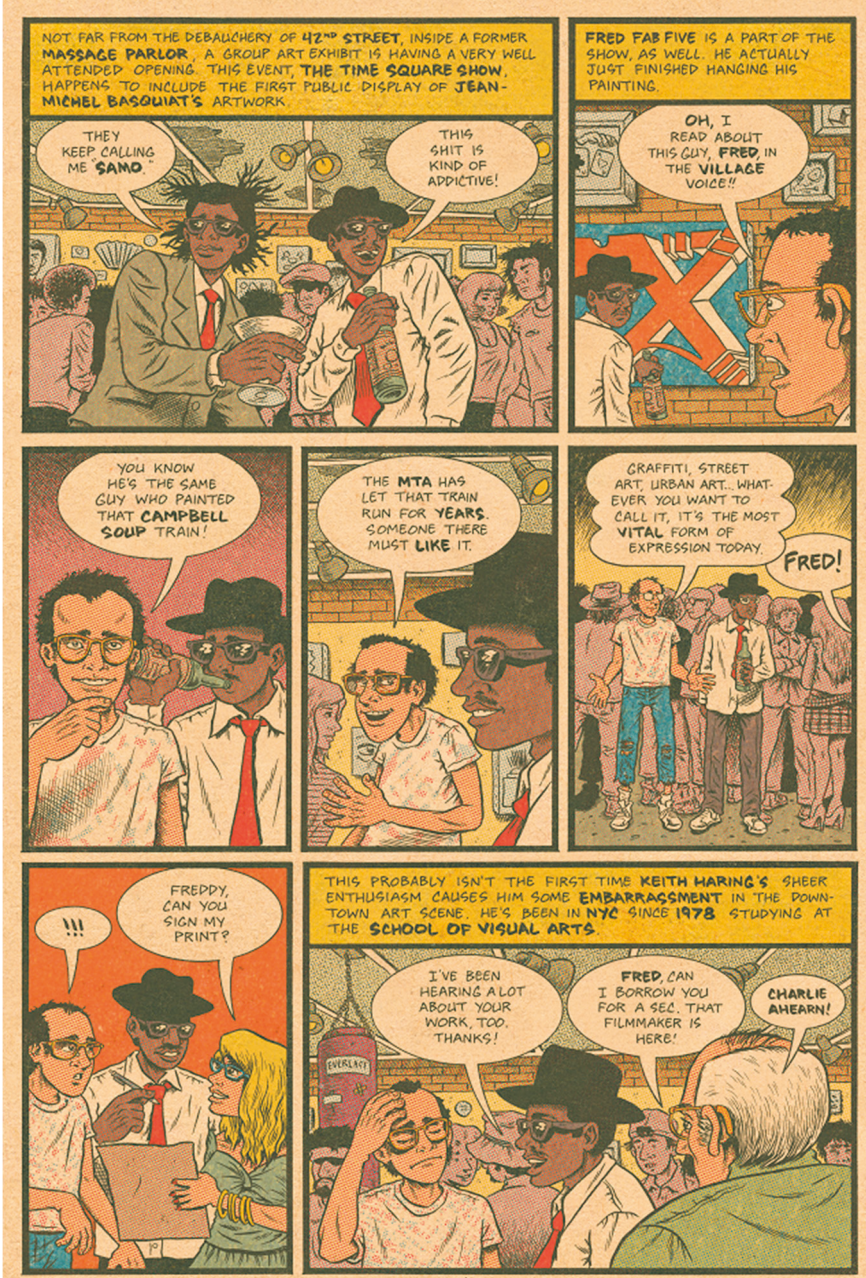

Figure 1. Excerpted page from Hip Hop Family Tree Treasury Edition 1.
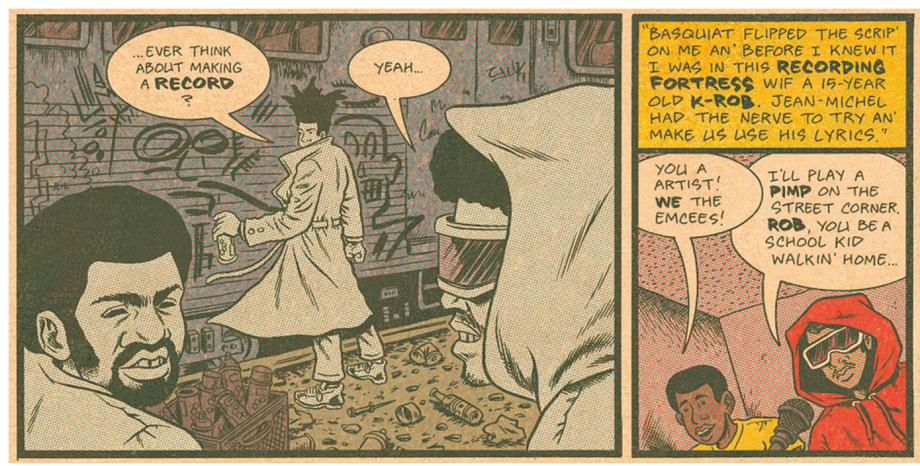

Figure 2. Excerpted two-panel detail from Hip Hop Family Tree Treasury Edition 2. 
The third treasury edition focuses on the years 1983 and 1984, with the ongoing thread on visual art shifting its attention to the work of Martha Cooper and Henry Chalfant. This pair of photographers became interested in documenting the emerging hip-hop scene, primarily through images of graffiti on subway trains, and their collaboration resulted in the publication of a book on the subject (Cooper and Chalfant 1984). Chalfant also collaborated with Tony Silver in producing a documentary, Style Wars (1983), that addresses the conflicts that graffiti artists face not just from legal authorities but also from parental disapproval, traditional fine art communities, and in competition with one another. Many of the artists featured in Style Wars—such as Mare 139, Dr. Revolt and Cey Adams-go on to have successful careers designing logos or even sculptural trophies for Black Entertainment Television, MTV, and several notable musical groups.

As in the previous edition, Piskor once again takes time to trace the emergence of a notable hip-hop musician - in this case, Lawrence Parker-who literally makes his mark as a graffiti artist before finding critical success as a musician. Through Piskor's comic art, readers learn that Parker likely developed his recording pseudonym, KRS-One, as a graffiti tag before ever committing his lyrics to record. Large portions of the third treasury edition also focus on the growing acceptance of notable rap acts, such as the Fat Boys and Run DMC, as they begin to find mainstream commercial success during this time period.

The fourth and final treasury edition features content from the years 1984 and 1985 . In comparison to the previous editions, this final installment seems to place less emphasis on the role of visual art in hip-hop culture and contains only a few passing references to the topic. In shorter passages than before, Piskor details graffiti artists-Phase 2 and Brim-who respectively participate in Steven Hager's (1984) book project on the history of hip-hop or the similarly-themed documentary produced by the British Broadcasting Corporation (Beat This: A Hip-Hop History 1984). There are also passing references to KRS-One's continued involvement in graffiti alongside Ced Gee, and also to Schoolly D who designs the cover art for his own self-produced 12-inch single.

Although visual art is featured less prominently, the fourth edition does devote more space to social justice issues and the growing presence of women in hip-hop as musicians with sustainable popular success. Salt 'N' Pepa are featured both within the storyline and on the cover art of this edition (Figure 3), and Piskor continues to document the career trajectory of Roxanne Shante as well. In terms of social commentary, the fourth edition offers more extensive sections looking critically at the proliferation of crack use in low-income urban communities, and the forceful reaction of the Los Angeles Police Department (LAPD) to this phenomenon through the use of V-100 commando tanks. Similarly, Piskor also describes deadly police confrontations with MOVE, a controversial Black liberation and back-to-nature organization in West Philadelphia, that also occurred during this time period. This section concludes with details about the subsequent movement to respond to these acts and others like them through politically-charged hip-hop lyrics and recordings. 


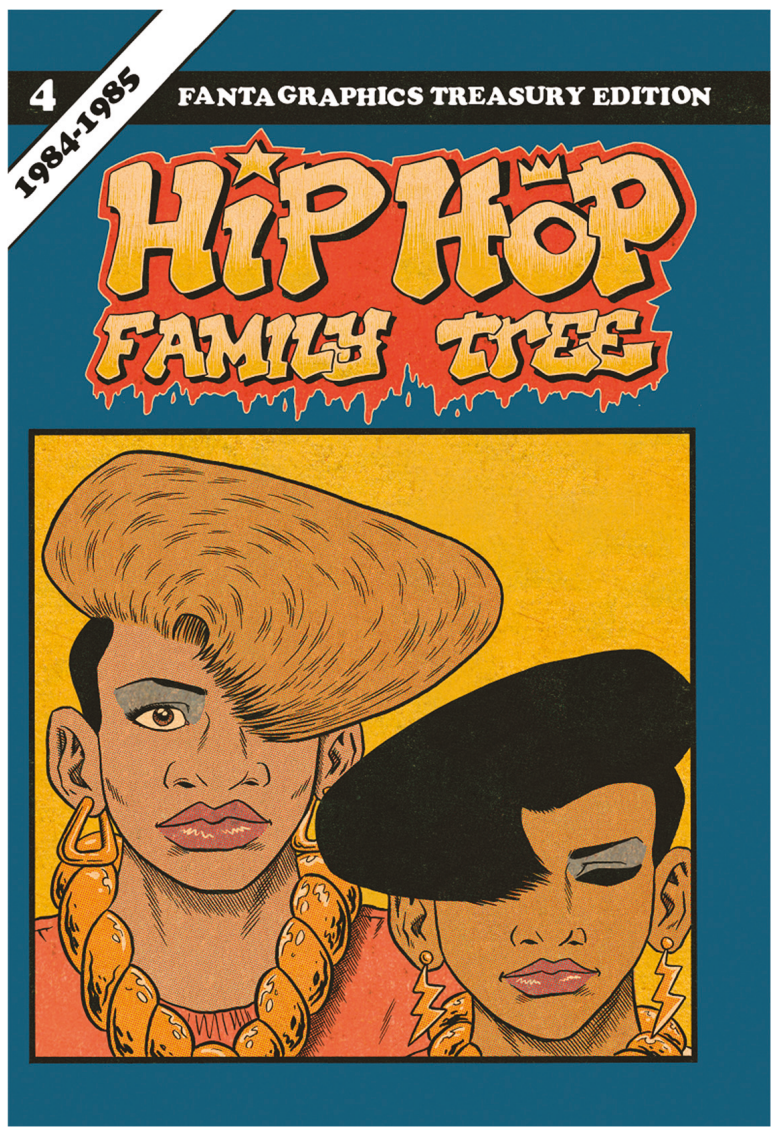

Figure 3. Cover of Hip Hop Family Tree Treasury Edition 4.

\section{Relevance to Art and Visual Culture Educators}

On the most basic level, Piskor's collected work is notable for blending together what may seem as two distinctly different genres of popular culture-hip-hop and comic books-and these volumes can be enjoyed and appreciated by fans of either. It is similarly obvious that Hip Hop Family Tree can also serve as an engaging educational tool for those interested in studying the history of hip-hop. On a deeper level, however, these treasury editions can serve as a supplementary resource for art and visual culture educators to use with their students when introducing postmodern principles, the use of historical and arts-based research methods, and in discussing a broad range of social justice and identity issues.

\subsection{A Resource for Teaching Principles of Postmodern Art}

When introducing the complex topic of postmodern art, secondary and higher education instructors may consider making comparisons to hip-hop music (Broome 2015) as a way to connect students' interests to hard-to-grasp postmodern principles, such as appropriation, recontextualizaton, and layering (Gude 2004). These postmodern principles are often recognizable in sample-based hip-hop music (Schloss 2004) where sounds are borrowed—or appropriated-from existing sources and then recontextualized and layered with other sounds to create new songs with potentially new meanings for these sampled components. Interestingly enough, Piskor's approach in creating Hip Hop Family 
Tree is also generally congruent with these postmodern principles and hip-hop aesthetics as well, as he employs several subtle uses of appropriation within select sections of these graphic novels. Most obviously, Piskor utilizes appropriation through the occasional layering of scanned images of musicians, album covers, book covers, and still-frames within a number of panels in his comic narrative, particularly in the fourth treasury edition.

In other instances-and in a manner similar to hip-hop musicians who sample from their own predecessors-Piskor cleverly appropriates and references historical conventions from within the comic book and animation industries as well. As an obvious example, the new art featured on the outside casing of the first box set is rendered in a style similar to classic silver-age comic book covers complete with a faux price tag of ten cents and a seal from the long-defunct comics code authority. Furthermore, the coloring of Hip Hop Family Tree is largely executed through the use of Ben-Day dots as a seemingly intentional reference to the production standards of comic book publishers during the era depicted within Piskor's graphic novel (Brown 2013). Less obviously, Piskor also incorporates popular culture iconography into the periphery of his text by hand-drawing appropriated imagery from other comic or animated sources such as Inspector Gadget, Beavis and Butthead, Archie Comics, and Fat Albert (with this latter image slyly implied to represent a young Biggie Smalls). Given the multiple uses of appropriation within Hip Hop Family Tree, art teachers may consider mixing some of these examples in with select hip-hop songs as a way to augment students' understanding of the postmodernism principles of appropriation, recontextualizaton, and layering.

\subsection{A Catalyst for Considering Historical or Arts Based Research}

Art and visual culture educators working in higher education may also find Hip Hop Family Tree to be a useful resource when instructing introductory coursework on research methods for Master's students. At its core, Hip Hop Family Tree is a graphic representation of the history of hip-hop and, as such, may serve as a motivational springboard for novice researchers in considering historical or arts-based approaches. In terms of historical methodology, Piskor's work may not hold the same rigor as that of a formally trained doctoral-level academic specializing in historical methods, yet the scope of his research appears to be extensive and thorough in terms of reviewing primary and secondary sources of literature, music, film, and other media. The point to impart on higher education students, then, may not be to uphold Piskor's use of research methods as a shining academic exemplar, but rather to broaden students' minds as to conducting historical research on topics of interest related to popular visual culture. Hip Hop Family Tree can be used to show students that historical research in art does not have to be limited to the confining boundaries of traditional conceptions of Western fine art.

Similarly, higher educators could also use Piskor's graphic novel as a catalyst for encouraging graduate students to consider alternative or unique ways to display their data or structure research findings. Ongoing developments in qualitative research have opened doors for possibilities in arts-based research, or ways in which art making can be used for collecting, interpreting, and analyzing data, or in presenting findings (Cahnmann-Taylor and Siegesmund 2008; Greenwood 2012). For arts-based researchers, data does not always have to be displayed as numbers or through the use of formally written academic language; instead data can be shared, analyzed, or discussed through almost any type of creative arts including, but not limited to paintings, poetry, theatrical productions, or even as graphic novels. Some arts-based researchers, such as Sousanis (2015) and Sally Campbell Galman $(2007,2013)$, have already received notable attention for using comic book formats in their work, and a number of art educators have experimented with these methods as well (Carpenter and Tavin 2010; Duffy 2009; Flowers 2017; Jones and Woglom 2013). Because of the accessibility of its content, writing style, and potentially interesting subject matter to students, the Hip Hop Family Tree series could easily serve as a motivational resource in spurring fledgling Master's students to consider using comic art or other arts-based methods in their future research. 


\subsection{Discussion of Social Justice and Identity Issues}

As with any other instructional resource, it's important that art and visual culture educators critically examine Hip Hop Family Tree prior to using it as a teaching tool. As a historical exploration of hip-hop culture, the text does contain several frank portrayals of the drug use, violence, explicit language, and misogynistic content that has at times accompanied certain situations and sub-genres surrounding hip-hop. While these depictions may provide opportunities for the critical deconstruction of popular imagery often associated with hip-hop culture (Chung 2007; Clinton 2010), other secondary teachers may find it wise to carefully screen the text before selecting specific excerpts to share with their students.

It should also be noted that Piskor is a White male (as am I), and that any subjectivities that may come along with his identity present worthy discussion points in analyzing his depiction of women or the historical development of a culture that largely grew out of Black urban environments. Initially, instructors could encourage critical dialogue related to the potentiality of such subjective representations through simple prompts asking students to openly consider the ways in which different characters and situations are portrayed in Piskor's narrative. Are some characters portrayed in semi-heroic proportions similar to those found in superhero genres of comic books? If so, why were those particular characters chosen to be portrayed in such a manner? Is the portrayal of women ever problematic in the course of Piskor's narrative? Is it possible that some figures essential to the history of hip-hop have been reduced to simplified comedic caricatures in terms of the way that they are depicted or speak? Is the use of such exaggerations ever problematic given that these characters are based on living persons rather than fictional heroes and villains? Is the use of phonetic vernacular dialogue-a practice with a long-running tradition in comic art (Pekar 1996)_ever problematic, given the context of the narrative and identity of the author? Such critical discussions may prepare students for more intense conversations that may arise in reaction to specific vignettes from Hip Hop Family Tree that detail forceful police interventions in Black communities. Several scenes (particularly those depicting the LAPD's use of commando tanks, and the Philadelphia Police Department's deadly confrontations with MOVE) are ripe for fostering classroom discussions on social justice issues, and also the deft ways that skillful artists approach such topics.

Although it is important to look at any text critically, Hip Hop Family Tree presents itself as a comprehensive work masterfully created by an authentic and genuine devotee to both hip-hop culture and the history and craft of comic book art. One gets the sense that Ed Piskor is passionate about both topics, fully immersed in both cultures, and that he would be just as enthusiastic, intelligent, and articulate in discussing the influence of Melle Mel, Dr. Dre, and the Beastie Boys as he would when discussing the impact of Jack Kirby, Harvey Pekar, and Robert Crumb on the art of making comics. In the end, Hip Hop Family Tree is a welcome and important addition to both scholarship on the history of hip-hop and to the graphic novel format. Art and visual culture art educators may find it as a useful resource in introducing aspects of postmodern art, in fostering early graduate students to consider historical and arts-based research methods, and in discussing relevant social justice and identity issues with students.

Funding: This research received no external funding.

Acknowledgments: The author would like to acknowledge and thank Joshua Drews, art teacher at Spring Valley High School in Columbia, South Carolina, for first introducing him to the Hip Hop Family Tree series.

Conflicts of Interest: The author declares no conflict of interest.

\section{References}

Beat This: A Hip-Hop History. 1984. Directed by Dick Fontaine. London: British Broadcasting Corporation. Broome, Jeffrey L. 2015. Using Hip-Hop Music to Enhance Critical Discussions on Postmodern Art. Art Education 68: 34-39. [CrossRef] 
Brown, Hillary. 2013. Hip Hop Family Tree by Ed Piskor. Paste. December 5. Available online: https://www. pastemagazine.com/articles/2013/12/hip-hop-family-tree-by-ed-piskor.html (accessed on 8 December 2018).

Cahnmann-Taylor, Melissa, and Richard Siegesmund, eds. 2008. Arts-Based Research in Education: Foundations for Practice. New York: Taylor \& Francis.

Carpenter, B. Stephen, II, and Kevin M. Tavin. 2010. Drawing (Past, Present, and Future) Together: A (Graphic) Look at the Reconceptualization of Art Education. Studies in Art Education 51: 327-52. [CrossRef]

Chung, Sheng Kuan. 2007. Media/visual Literacy Art Education: Sexism in Hip-hop Music videos. Art Education 60: 33-38. [CrossRef]

Clinton, Zerric. 2010. What African American Male Adolescents Say about Music Videos with Implications for Art Education. Ph.D. dissertation, Florida State University, Tallahassee, FL, USA.

Cooper, Martha, and Henry Chalfant. 1984. Subway Art. New York: Holt, Rinehart and Winston.

Downtown 81. 2000. Directed by Edo Bertoglio. New York: Glen O’Brien and Maripol.

Duffy, Damian. 2009. Learning from Comics on the Wall: Sequential Art Narrative Design in Museology and Multimodal Education. Visual Arts Research 35: 1-11.

Flowers, Ebony. 2017. Experimenting with Comics Making as Inquiry. Visual Arts Research 85: 21-57. [CrossRef]

Fricke, Jim, and Charlie Ahearn. 2002. Yes Yes Y'all: The Experience Music Project Oral History of Hip-Hop's First Decade. Cambridge: Da Capo.

Galman, Sally Campbell. 2007. Shane, the Lone Ethnographer: A Beginner's Guide to Ethnography. Lanham: AltaMira Press.

Galman, Sally Campbell. 2013. The Good, the Bad, and the Data: Shane, the Lone Ethnographer's Basic Guide to Qualitative Data Analysis. Walnut Creek: Left Coast Press.

Greenwood, Janika. 2012. Arts-based Research: Weaving Magic and Meaning. International Journal of Education $\mathcal{E}$ the Arts 13: 1-20.

Gude, Olivia. 2004. Postmodern Principles: In Search of a 21st Century Art Education. Art Education 57: 6-14. [CrossRef]

Hager, Steven. 1984. Hip Hop: The Illustrated History of Break-Dancing, Rap Music, and Graffiti. New York: St. Martin's Press.

Jones, Stephanie, and James Woglom. 2013. Graphica: Comics Arts-Based Educational Research. Harvard Educational Review 83: 168-89. [CrossRef]

Nosnitsky, Andrew. 2013. Basquiat's 'Beat Bop': An Oral History of One of the Most Valuable Hip-Hop Records of All Time. Spin. November 14. Available online: http://www.spin.com/articles/beat-bop-basquiat-k-robrammellzee-freak-freak/ (accessed on 6 December 2018).

Pekar, Harvey. 1996. Getting Serious About the Funnies. Chicago Tribune. January 21. Available online: https: //www.chicagotribune.com/news/ct-xpm-1996-01-21-9601210089-story.html (accessed on 8 December 2018).

Piskor, Ed. 2012. “Brain Rot: Hip Hop Family Tree, DJ Kool Herc Spawns a New Culture," Boing Boing (Group Blog), Jason Weisberger. January 10. Available online: https://boingboing.net/2012/01/10/brainrot-hip-hop-family-tree.html (accessed on 2 December 2018).

Piskor, Ed. 2014. Hip Hop Family Tree: 1975-1983. [Gift Box Set]. Seattle: Fantagraphics.

Piskor, Ed. 2016. Hip Hop Family Tree: 1983-1985. [Gift Box Set]. Seattle: Fantagraphics.

Schloss, Joseph G. 2004. Making Beats: The Art of Sample-Based Hip-Hop. Middletown: Wesleyan University Press. Sousanis, Nick. 2015. Unflattening. Cambridge: Harvard University Press.

Style Wars. 1983. Directed by Tony Silver. New York: Public Art Films.

Wild Style. 1983. Directed by Charlie Ahearn. New York: First Run Features.

(C) 2018 by the author. Licensee MDPI, Basel, Switzerland. This article is an open access article distributed under the terms and conditions of the Creative Commons Attribution (CC BY) license (http:/ / creativecommons.org/licenses/by/4.0/). 
MDPI

St. Alban-Anlage 66

4052 Basel

Switzerland

Tel. +41 616837734

Fax +41 613028918

www.mdpi.com

Arts Editorial Office

E-mail: arts@mdpi.com

www.mdpi.com/journal/arts

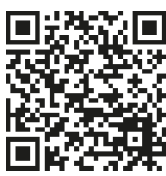





\section{MDPI}

St. Alban-Anlage 66 4052 Basel

Switzerland

Tel: +41 616837734

Fax: +41 613028918 